UNIVERSIDADE DE SÃO PAULO

FACULDADE DE ZOOTECNIA E ENGENHARIA DE ALIMENTOS

Agostinho Domingos Miguel Francisco

Eficiência de fontes de nitrogênio e enxofre na composição Químico-Bromatológica e algumas características agronômicas da cultura de milho (Zea mays L.) em sistema de plantio direto.

Pirassununga

2008 
Agostinho Domingos Miguel Francisco

Eficiência de fontes de nitrogênio e enxofre na composição Químico-Bromatológica e algumas características agronômicas da cultura de milho (Zea mays $L$.) em sistema de plantio direto.

Dissertação apresentada à Faculdade de Zootecnia e Engenharia de Alimentos da USP, como parte dos requisitos para obtenção do Título de Mestre em Zootecnia.

Área de concentração: Qualidade e Produtividade Animal.

Orientador : Prof. Dr. Pedro Henrique de Cerqueira Luz

Pirassununga/SP - Brasil

2008 


\title{
FICHA CATALOGRÁFICA
}

\author{
preparada pela
}

Biblioteca da Faculdade de Zootecnia e Engenharia de Alimentos da Universidade de São Paulo

\section{Francisco, Agostinho Domingos Miguel}

F819e Eficiência de fontes de nitrogênio e enxofre na composição químico-bromatológica e algumas características agronômicas da cultura de milho (Zea mays L.) em sistema de plantio direto / Agostinho Domingos Miguel Francisco - Pirassununga, 2008.

$129 \mathrm{f}$.

Dissertação (Mestrado) -- Faculdade de Zootecnia e Engenharia de Alimentos - Universidade de São Paulo

Departamento de Zootecnia

Área de Concentração: Qualidade e Produtividade Animal

Orientador: Prof. Dr. Pedro Henrique de Cerqueira Luz

Unitermos: 1. Coletores semi-aberto 2. Fertilizantes 3.

Volatilização de amônia 4. Perdas de nitrogênio. I. Título. 
A DEUS, por me conceder força, saúde e sabedoria para buscar os meus ideais; permitindo-me crescer profissional e espiritualmente; aos meus pais Domingos Pedro Francisco (in memorium) e Teresa Adão Miguel, pelo amor que me dedicaram e pelos bons exemplos de vida que contribuíram para a formação do meu caráter e dos meus valores, mesmo não estando perto, sempre estiveram presente em meu coração, e, Bibiana Jepele Sapuile Francisco, esposa incansável companheira, com amor, admiração e gratidão pela sua compreensão, carinho e incentivos.

\section{DEDICO}

Aos meus filhos,

David Kiala Jepele Francisco e Ariela de Fátima Justa Francisco,

Luz da minha vida

OFEREÇO 


\section{AGRADECIMENTOS}

- Ao Prof. Dr. Pedro Henrique de Cerqueira Luz, pela contribuição para minha formação e pela orientação na condução deste trabalho.

- Aos meus irmãos Pedro Domingos Miguel, Esperança Domingos Miguel, Lemba Domingos Miguel, Adão Domingos Miguel, António Domingos Miguel e Lusia Domingos Miguel pelo amor, confiança e apoio nesta minha caminhada.

- Aos meus primos Baltazar Mateus, Eugênia Mateus, Nazaré Mateus, Mateus Pedro por tudo que fizeram para que eu chegasse até aqui.

- Aos amigos de Pós-graduação envolvidos neste trabalho Felipe Barros Macedo, Letícia de Abreu Faria, Ana Carolina Alves, que estiveram desde o início da implantação da área experimental assim como no decorrer do experimento, com certeza que tiveram um importante papel para a conclusão deste trabalho.

- À família Macedo, pela amizade demonstrada, pela atenção dispensada, pelo apoio incansável para o cumprimento dos objetivos programados.

- Aos funcionários Anderson Luiz dos Santos, Geisa Martin de Freitas, Glaziela Baptistella, Marcos Roberto Ferraz e Paulo Sérgio Tonetti. Aos estagiários do Laboratório de Solos, ao funcionário Raphael J. C. Júnior do Laboratório de Proteínas e às funcionárias Roseli S. Lacerda e Rosilda C. M. Loura do Laboratório de Análise de Alimentos (Bromatologia) pelo apoio na execução das análises laboratoriais sempre que é necessário.

- À Universidade Agostinho Neto, à Faculdade de Ciências Agrárias (FCA), pela oportunidade de realização do Curso de Pós-graduação.

- Aos funcionários da secção de Pós-Graduação Vagner, Conceição, Gláucia e Laila pelos serviços prestados.

- Ao Prof. Dr. José Bento Sterman Ferraz, pelo incentivo, sugestões, amizade e apoio no ingresso a Pós-graduação.

- Ao Prof. Dr. Júlio Cesar de Carvalho Balieiro, pelo serviço estatístico prestado. 
- À Dra. Patrícia P. A. Oliveira pela colaboração, atenção, paciência e ensinamentos.

- A CNPq, pela concessão da Bolsa de estudos de mestrado.

- À SN-Centro, pelo financiamento do projeto.

- Ao Prof. Dr. Valdo Rodrigues Herling, pelo apoio e incentivos constantes.

- À Universidade de São Paulo (USP), à Faculdade de Zootecnia e Engenharia de Alimentos (FZEA), e ao Departamento de Zootecnia pela oportunidade de realização do Curso de Pós-graduação.

- Aos funcionários do Setor Agrícola, em especial ao Eduardo Ferraz de Almenio e José Marau de Godói.

- À Naira Cristina Zero, pelo apoio prestado na preparação dos reagentes e embalagem das espumas que continha amônia.

- Aos meus amigos João Sergio Raul, Benedito António Marcos, Lourenço Bartolomeu Caetano, Manoel da Silva Caetano e Tomas Vasconselho Raul pelo apoio que tiveram em ajudar a minha família durante a realização da Pós-graduação.

- A todos os colegas de Mestrado da FZEA com quem dividi as alegrias, tristezas e dificuldades no período.

- Aos companheiros da Moradia Estudantil, Daniel, Otávio, Willian com os quais tive o grande prazer de dividir a moradia durante o curso.

- E a todos que direta ou indiretamente colaboraram para a realização deste trabalho, o meu muito obrigado. 
"SE A MINHA VISTA ALCANÇASSE AONDE O PENSAMENTO VAI, TALVÉZ NÃO SOFRESSE TANTO POR NÃO VER O MEU PAÍS"

(Autor desconhecido) 


\section{RESUMO}

Francisco, Agostinho Domingos Miguel. Eficiência de fontes de nitrogênio e enxofre na composição químico-bromatológica e algumas características agronômicas da cultura de milho (Zea mays L.) em sistema de plantio direto. 2008. 129 f. Dissertação (Mestrado) - Faculdade de Zootecnia e Engenharia de Alimentos, Universidade de São Paulo, Pirassununga, 2008.

O presente trabalho foi desenvolvido no Departamento de Zootecnia da Faculdade de Zootecnia e Engenharia de Alimentos da Universidade de São Paulo - FZEA/USP localizada em Pirassununga-SP no período de 16/12/2006 a 10/05/2007 em condições de campo com o cultivo do híbrido do milho super precoce GNZ-2005 em Latossolo Vermelho Amarelo distrófico férrico. O experimento teve como objetivo avaliar a eficiência de fertilizante nitrogenado FASN (Fusion Amonium Sulfate Nitrate) comparado na composição químicobromatológica e algumas características agronomicas da cultura de milho (Zea mays L.) à fontes tradicionais de nitrogênio como nitrato de amônio, uréia e sulfato de amônio, implantado no sistema plantio direto. Foram avaliadas as perdas de nitrogênio por volatilização da amônia, os atributos químicos e físicos do solo, rendimento de grãos $\left(\mathrm{kg} \mathrm{ha}^{-1}\right)$, matéria seca total (\%) e análise bromatológica e foliar. A dose de nitrogênio foi $100 \mathrm{~kg} \mathrm{ha}^{-1}$ de $\mathrm{N}$ em todos os tratamentos, exceto nas testemunhas (T1 e T2), que também receberam 450 $\mathrm{kg} \mathrm{ha}^{-1}$ de 8:28:16 + 0,5\% de Zn. O delineamento experimental foi em blocos completos casualizados, com dez tratamentos e quatro repetições. Os tratamentos foram: T1: Testemunha +Gesso (-N+S), T2: Testemunha absoluta (-N-S), T3: Uréia - 45\% N, T4: Uréia + Gesso 14\%S, T5: Uréia + sulfato de amônio - 21\%N /24\%S-(33:00:00+12\%S), T6: Nitrato de amônio - 30\%N, T7: Nitrato de amônio - 30\%N + gesso, T8: Nitrato de amônio + Sulfato de Amônio - 21\% N/ 24\%S - (27,8:00:00+6\%S), T9: Sulfato de amônio, T10: FASN 26\%N/14\%S. Perdas por volatilização de amônia foram avaliadas em todos os tratamentos de T1 a T10 por meio de coletores semi-abertos estáticos colocados em cada parcela em que se estudou a volatilização. Foram 
colocadas cinco bases para cada coletor, onde se aplicou as fontes nitrogenadas na dose de $100 \mathrm{~kg} \mathrm{ha}^{-1}$ de $\mathrm{N}$. O N-NH 3 volatilizado foi retido em espumas embebidas em solução ácida e extraída com solução ácido clorídrico para posterior quantificação das perdas. A avaliação do estado nutricional das plantas, de atributos químicos e físicos do solo, volatilização de amônia, características bromatológicas e a produtividade foram efetuadas em todos os tratamentos. A avaliação do estado nutricional foi feita pela análise química dos teores de nutrientes nas folhas coletadas no florescimento. Atributos químicos do solo foram avaliados por meio de análises laboratoriais de amostras coletadas nas camadas de 0 a 20 e de 20 a $40 \mathrm{~cm}$ de profundidade, após a colheita do milho. Dentre das fontes nitrogenadas avaliadas, a uréia implicou em maiores perdas de nitrogênio $\mathrm{N}-\mathrm{NH}_{3}$ aos seis dias após aplicação. Com relação ao desempenho geral das fontes de nitrogênio, pode-se constatar que o FASN teve comportamento similar ao do sulfato de amônio e do nitrato de amônio.

Palavras-chave: coletores semi-aberto; fertilizantes; volatilização de amônia , perdas de $\mathrm{N}$. 


\begin{abstract}
Francisco, Agostinho Domingos Miguel. Efficiency of sources nitrogen and sulfur in chemical-bromatologic composition and some characteristics of de corn (Zea mays L.) culture in no-tillage system. 2008. 129 f. M.Sc. Dissertation - Faculdade de Zootecnia e Engenharia de Alimentos, Universidade de São Paulo, Pirassununga, 2008.
\end{abstract}

This experiment was developed in Departamento de Zootecnia in Faculdade de Zootecnia e Engenharia de Alimentos of the Universidade de São Paulo - FZEA/USP located in Pirassununga-SP in the period from 16/12/2006 to $10 / 05 / 2007$ in field conditions with culture of the super precocious the early hybrid mayze GNZ-2005 in ferric and distrophic Red Latosol (Oxisol). Objective was to evaluate in the efficiency of nitrogen fertilizer FASN (Fusion Ammonium Sulfate Nitrate) about chemical-bromatologic and feed composition and some characteristics of the corn culture (Zea mays L.) compared to traditional sources of nitrogen such as ammonium nitrate, urea and ammonium sulfate under notillage system. There were evaluated the loss of nitrogen by ammonium volatilization, the chemicals and physical attributes of soil, grain yield $\left(\mathrm{Kg} \mathrm{ha}^{-1}\right)$, total dry matter (\%) and bromatologic and leaf composition. Nitrogen level utilized was $100 \mathrm{~kg} \mathrm{ha}^{-1}$ of $\mathrm{N}$ in all treatments, except to controls (T1 and T2) and all treatments received $450 \mathrm{~kg} \mathrm{ha}^{-1}$ of $8: 28: 16+0,5 \%$ of $\mathrm{Zn}$. The experimental design was a completely randomized blocks with ten treatments and four repetitions. The treatments were: T1: control+ gypsum $(-\mathrm{N}+\mathrm{S}), \mathrm{T} 2$ : absolute control (-N-S), T3: urea - 45\% N, T4: urea + gypsum 14\%S, T5: urea + ammonium sulfate $-21 \% \mathrm{~N} / 24 \% \mathrm{~S}-(33: 00: 00+12 \% \mathrm{~S})$, T6: ammonium nitrate $-30 \% \mathrm{~N}$, T7: ammonium nitrate $-30 \% \mathrm{~N}+$ gypsum, T8: ammonium nitrate + ammonium sulfate $-21 \% \mathrm{~N} / 24 \% \mathrm{~S}-(27,8: 00: 00+6 \% \mathrm{~S})$, T9: ammonium sulfate, T10: FASN 26\%N/14\%S. Losses by volatilization of ammonia were evaluated in all treatments (T1 to T10) with static semi-open collectors were placed in each plots for study the volatilization. Were placed five bases for collector that were applied the $100 \mathrm{~kg} \mathrm{ha}^{-1}$ of $\mathrm{N}$ of nitrogen sources.. The $\mathrm{N}$ - 
$\mathrm{NH} 3$ volatilized was restrained in foam absorbed in acid solution and extracted with hydrochloric acid solution to after quantification of the losses. The evaluation of nutritional state of the plants, of soil chemical and physical attributes, ammonia volatilization, feed composition and productivity were realized in all the treatments. The evaluation of nutritional state was made for chemical analysis of leaves nutrients that were collected in bloom. Soil chemical attributes were evaluated with samples collected in 0 to 20 and 20 to $40 \mathrm{~cm}$ depth after maize collected. Among Nitrogen sources evaluated, the urea had the most nitrogen $\mathrm{N}-\mathrm{NH}_{3}$ losses in the 6 days after application. In relation to the nitrogen sources performances, the FASN had similar behavior to the ammonium sulfate and ammonium nitrate.

Key-words: semi-open collectors, fertilizers, volatilization of ammonium, losses of $\mathrm{N}$. 


\section{LISTA DE FIGURAS}

FIGURA 1. ÁREA ANTES DE A INSTALAÇÃO DO EXPERIMENTO. ............................. 53

FIgURA 2. ÁREA ANTES DE A INSTALAÇÃO DO EXPERIMENTO. ............................. 53

FIGURA 3. MARCAÇÃO DA ÁREA DO EXPERIMENTO. ........................................ 54

FIGURA 4. MARCAÇÃO DA ÁREA DO EXPERIMENTO. ....................................... 54

FIGURA 5. ESTAÇÃO DE METEOROLOGIA DA FZEA/USP............................... 55

FIgURA 6. TEMPERATURA $\left({ }^{\circ} \mathrm{C}\right)$ MÁXIMA, MÍNIMA E MÉdIA DURANTE O PERÍODO

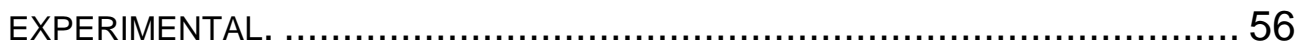

FiguRA 7. PRECIPITAÇÃo (MM) MÁXIMA, MíNIMA E MÉdIA DURANTE O PERÍOdO

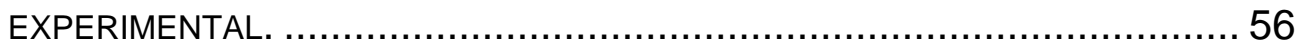

FIGURA 8. UMIDADE DO AR (\%) MÁXIMA, MÍNIMA E MÉDIA DURANTE O PERÍODO EXPERIMENTAL. ......................................................................... 57

FIGURA 9. CROQUI E ÁREA ÚTIL DO EXPERIMENTO..................................... 58

FIgURA 10. AdUBAÇÃO DE PLANTIO E SEMEADURA DE MILHO.............................. 60

FIGURA 11. AdUBAÇÃO DE COBERTURA NO MILHO. ...................................... 62

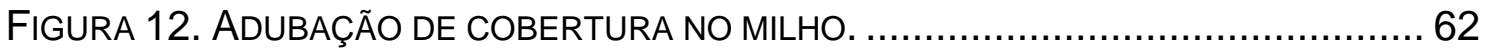

FIgURA 13. DETALHE DAS BASES PARA MUDANÇA DE POSIÇÃO DOS COLETORES. ..... 65

FIGURA 14. DETALHE dOS COLETORES DE AMÔNIA INSTALADOS NO CAMPO. .............6 65

FIGURA 15. EMBEBECIMENTO DAS ESPUMAS DO COLETOR SEMI-ABERTO COM ÁCIDO

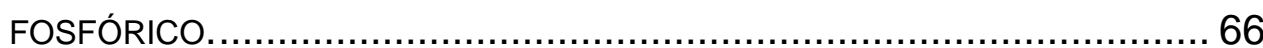

Figura 16. DetalHE dE TROCA DE ESPUMAS EMBEBIDAS EM SOLUÇÃo DE ÁCIDO

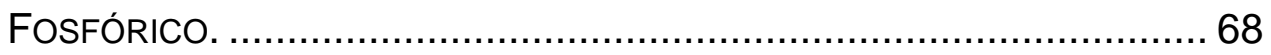

FIGURA 17. ESPUMAS QUE CONTÉM AMÔNIA DEPOIS DA SUA RETIRADA NO CAMPO E COLOCADAS E CONDICIONADAS A REFRIGERAÇÃO.........................6 69

FIGURA 18. LAVAGEM DA ESPUMA SOBRE O FUNIL DE PORCELANA PARA A RETIRADA DA AMÔNIA 69

FIgURA 19. DESTILAÇÃO DE AMÔNIA $\left(\mathrm{NH}_{3}\right)$. 71

FIGURA 20. ESTIMATIVAS DAS PERDAS DE N-NH 3 VOLATILIZADO (MG/PARC/DIA) PROVENIENTE DE FONTES NITROGENADAS. ............................... 80

FIgURA 21. RECUPERAÇÃO APARENTE DE N NO GRÃO DE MILHO. 81

FIGURA 22. EFEITO DO DIAS DE MONITORAMENTO SOBRE OS TRATAMENTOS AVALIADOS PARA O TOTAL MÉDIO DE NITROGÊNIO VOLATILIZADO TOTAL (TMNVT). . 85 


\section{LISTA DE TABELAS}

TABela 1. Atributos Químicos do SOlO ANTES dA INSTALAÇÃO dO EXPERIMENTO NAS CAMADAS DE 0-20 E 20-40 M, PARA MACRONUTRIENTES. 51

TABELA 2. ATRIBUTOS QUíMICOS DO SOLO ANTES DA INSTALAÇÃO DO EXPERIMENTO NAS CAMADAS DE 0-20 E 20-40, PARA MICRONUTRIENTES.

TABELA 3. AtRIBUtOS FíSICOS dO SOLO dA ÁREA EXPERIMENTAL/ANÁLISE GRANULOMÉTRICA 52

TABELA 4. TRATAMENTOS EXPERIMENTAIS UTILIZADOS NO PRESENTE TRABALHO PARA VERIFICAR À EFICIÊNCIA DAS FONTES NITROGENADAS QUANTO A COMPOSIÇÃO QUÍMICO-BROMATOLÓGICO E ALGUMAS CARACTERÍSTICAS AGRONÔMICAS 59

TABELA 5. EQUAÇÕES DA TAXA MÉdIA DE NITROGÊNIO VOLATILIZADO TOTAL (TMNVT)

TABELA 6. NITROGÊNIO VOLATILIZADO TOTAL ACUMULADO(NVTac). .84

TABELA 7. TEORES FOLIARES DE NUTRIENTES CONSIDERADOS ADEQUADOS PARA A CULTURA DO MILHO. 88

TABELA 8. TEORES DE MACRONUTRIENTES FOLIARES NO MILHO. 89

TABELA 9. TEORES DE MICRONUTRIENTES FOLIARES NO MILHO 90

TABELA 10. UMidAdE dO GRÃO (UG\%), NÚMERO DE PLANTAS (No.PLANTAS), PRODUTIVIDADE CORRIGIDA (PROD. _COR. KG HA ${ }^{-1}$ ) E EFICIÊNCIA NO GRÃO DE MILHO (\%).

TABELA 11. TEORES DE MACRONUTRIENTES NO SOLO AMOSTRAdOS APÓS A APLICAÇÃO DOS TRATAMENTOS NA PROFUNDIDADE DE 0-20 cM . 95

TABELA 12. TEORES DE MICRONUTRIENTES NO SOLO AMOSTRADOS APÓS A APLICAÇÃO DOS TRATAMENTOS NA PROFUNDIDADE DE 0-20 CM 96

TABELA 13. Atributos Químicos do SOlO MOSTRAdOS APÓS APLICAÇÃO DOS TRATAMENTOS NA PROFUNDIDADE DE 20-40 CM. 99

TABela 14. Teores bromatológicos (\%) matéria seca no grão (MSGrão), PROTEÍNA BRUTA (PB), FIBRA EM DETERGENTE ÁCIDO (FDA), FIBRA EM DETERGENTE NEUTRO NO GRÃO DE MILHO DEPOIS DA COLHEITA. ....... 101 


\section{SUMÁRIO}

1 INTRODUÇÃO

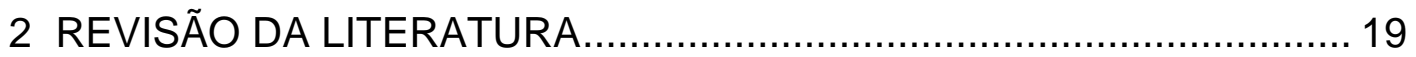

2.1 ASPECTOS PRINCIPAIS DA CULTURA DO MILHO....................... 19

2.2 CARACTERÍSTICAS DAS PRINCIPAIS FONTES NITROGENADAS.

2.3 MANEJO DO SOLO E RECOMENDAÇÃO DE ADUBAÇÃO

NITROGENADA PARA MILHO....................................................... 27

2.4 PERDAS E EFICIÊNCIA DO USO DO NITROGÊNIO PELO MILHO 35

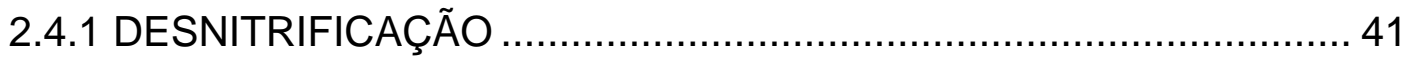

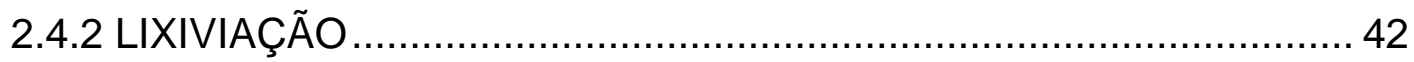

2.5 MINERALIZAÇÃO E MÉTODOS PARA DETERMINAÇÃO DE PERDAS

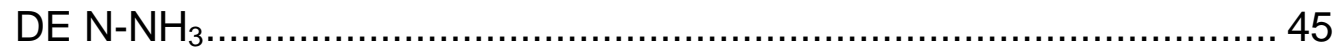

2.6 QUALIDADES NUTRICIONAIS DO MILHO ……................................ 48

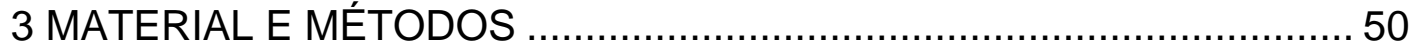

3.1 LOCALIZAÇÃO E CARACTERIZAÇÃO DA ÁREA EXPERIMENTAL

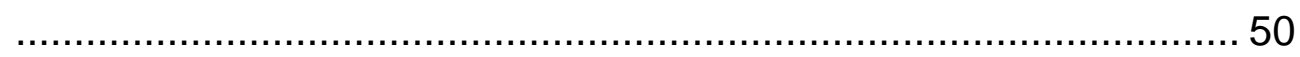

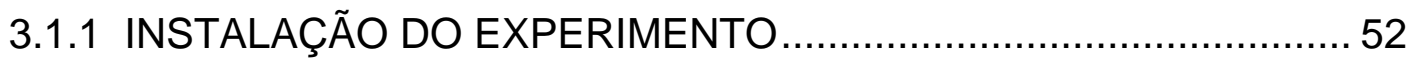

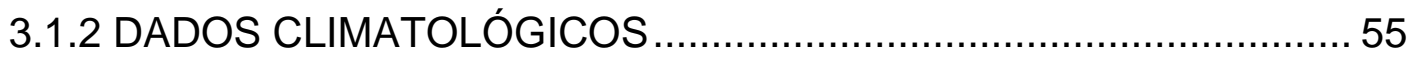

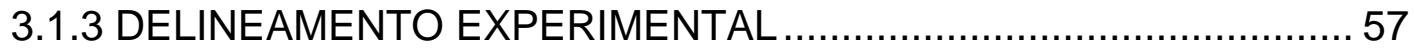

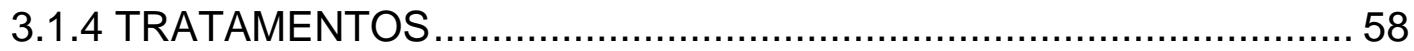

3.1.5 ADUBAÇÃO DE PLANTIO E SEMEADURA DO MILHO..................60

3.1.6 ADUBAÇÃO DE COBERTURA E TRATOS CULTURAIS DO MILHO 61

3.1.7 CARACTERÍSTICA DO HÍBRIDO UTILIZADO ............................... 63

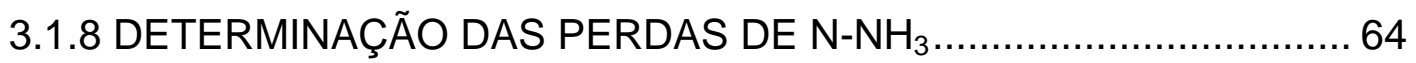

3.1.9 ESTADO NUTRICIONAL DA PLANTA DE MILHO ......................... 72

3.1.10 DETERMINAÇÃO DE PRODUTIVIDADE.................................... 73

3.1.11 ANÁLISE DO SOLO DEPOIS DA COLETA DO MILHO ................. 73

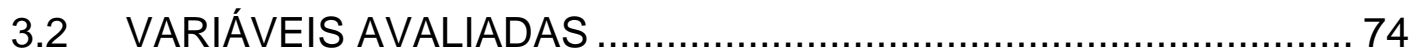

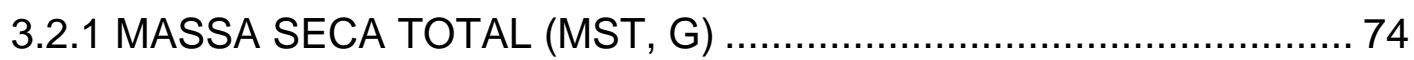

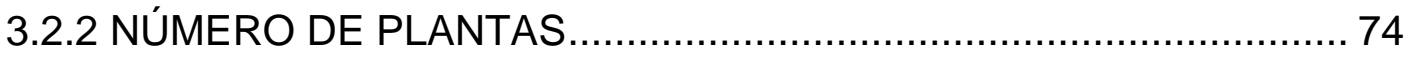


3.2.3 RENDIMENTO DE GRÃOS (RG, KG HA ${ }^{-1}$ ) .............................. 74

3.2.4 PROTEÍNA BRUTA (PB \%) ...................................................... 75

3.2.5 TEOR DE FIBRA EM DETERGENTE ÁCIDO E EM DETERGENTE

NEUTRO (FDA E FDN \%) NO GRÃO DE MILHO.......................... 75

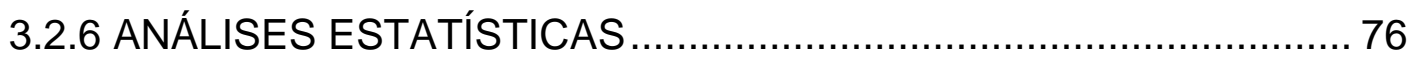

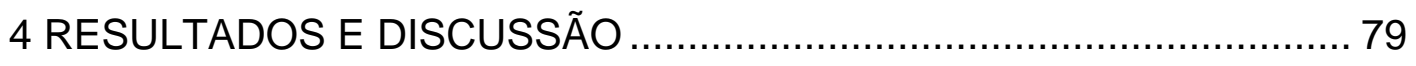

4.1 PERDA ACUMULADA DE N-NH ${ }_{3}$ DAS FONTES NITROGENADAS .. 79

4.2 AVALIAÇÃO DO ESTADO NUTRICIONAL DO MILHO....................... 87

4.2.1 TEORES FOLIARES DE MACRONUTRIENTES ........................... 87

4.2.2 TEORES FOLIARES DE MICRONUTRIENTES............................. 89

4.3 AVALIAÇÃO DA PRODUTIVIDADE E DOS ATRIBUTOS

QUALITATIVOS DO MILHO …....................................................... 91

4.4 PROPRIEDADES QUÍMICAS DO SOLO APÓS A CULTURA DE

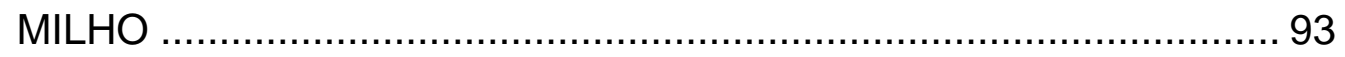

4.5 CARACTERÍSTICAS BROMATOLÓGICAS DA CULTURA DE MILHO 100

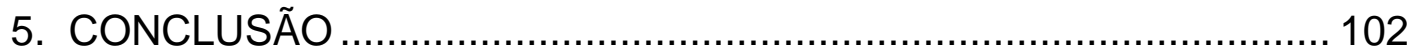

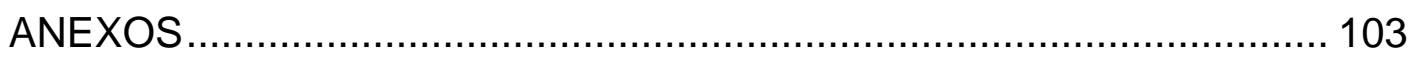

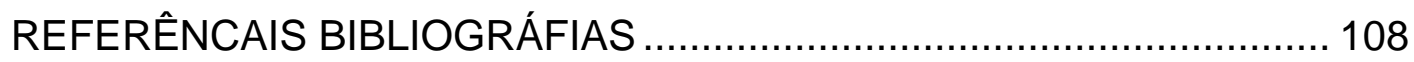




\section{INTRODUÇÃO}

O milho (Zea mays L.), em função do seu potencial produtivo, composição química e valor nutritivo, constitui num dos mais importantes cereais cultivados e consumidos no mundo. Em termos de produção, o Brasil é o terceiro maior produtor mundial $\left(58,6 \mathrm{t} / \mathrm{ha}^{-1}\right)$, sendo que o rendimento médio de grãos da cultura no Estado de SP é de 46,8 t/ha ${ }^{-1}$ (CONAB, 2008). O nitrogênio $(N)$ é o nutriente que mais freqüentemente limita o rendimento de grãos de milho, mas também é o que proporciona as maiores respostas para a cultura. O custo crescente e/ou perda dos fertilizantes nitrogenados demanda práticas de manejo que resulta em alta eficiência de utilização de $\mathrm{N}$ pelas culturas. No manejo de $\mathrm{N}$ em sistemas agrícolas deve-se considerar, os riscos ao ambiente, uma vez que este nutriente está sujeito a elevadas perdas por erosão, lixiviação, desnitrificação e volatilização. Desta forma, o manejo ideal da adubação nitrogenada deve ser definido como sendo aquele que permite satisfazer a necessidade da cultura, mas com o mínimo de risco ao ambiente.

A presença de resíduos culturais sobre a superfície do solo influência a quantidade de nitrogênio que se perde através da volatilização de amônia, especialmente quando a uréia é aplicada superficialmente (VARSA et al., 1995). Isto é relevante principalmente no sistema de plantio direto (SPD), onde grande parte dos agricultores efetua a adubação de cobertura com uréia, em aplicações superficiais e a lanço. Além disso, o incremento do conteúdo de matéria orgânica (MO) verificado nas camadas superficiais do solo cultivado em SPD, tende aumentar a população microbiana e a capacidade de troca cationica CTC (BAYER \& MIELNICZUK, 1997). Com isto, tem-se maior atividade da urease, que catalisa a hidrólise da uréia, favorecendo a volatilização de $\mathrm{NH}_{3}$. A presença de resíduos vegetais sobre a superfície do SPD também reduz o contato da uréia com o solo (MENGEL, 1996), diminuindo a absorção de $\mathrm{NH}_{4}{ }^{+}$aos colóides orgânicos e inorgânicos, e com isto facilitando a volatilização de amônia.

A eficácia do sistema de semeadura direta na redução da erosão hídrica depende fundamentalmente da quantidade de resíduos e da cobertura do solo ocasionada pelos restos vegetais das culturas. A cobertura do solo dissipa a 
energia cinética das gotas de chuva, diminuindo a desagregação pelo impacto das gotas e a erosão hídrica entre os sulcos do solo (Schaefer et al., 2001). O aumento da quantidade de resíduos vegetais na superfície do solo, por outro lado, aumenta o volume de água armazenado e a infiltração, diminuindo dentro de certos limites, o escoamento superficial e a erosão hídrica (Foster et al., 1982; Bertol et al., 1997; Morais \& Cogo, 2001).

Sabe-se que o nitrogênio é o nutriente absorvido em maior quantidade pelo milho, e também o que mais influência a resposta em produtividade de grãos e o que mais onera no custo de produção da cultura, tendo sua dinâmica no sistema solo-planta condicionada pelo sistema de manejo e condições edafoclimáticas (Amado et al., 2002).

A adubação nitrogenada de cobertura constitui-se num dos mais freqüentes questionamentos, especialmente em relação a fontes e ao método de aplicação. As fontes de $\mathrm{N}$ mais utilizadas na agricultura brasileira são uréia e sulfato de amônio. A uréia, pelas suas características e reação no solo, apresenta grande potencial de perda de $\mathrm{NH}_{3}$, por volatilização (KELLER \& MENGEL, 1986; LARA CABEZAS \& TRIVELIN, 1990) e o sulfato de amônio, apresenta pequena perda de $\mathrm{NH}_{3}$ (BARBOSA FILHO et al., 2001). A utilização dessas fontes de nitrogênio requer, portanto, que as técnicas de manejo da aplicação sejam aperfeiçoadas, de modo que os produtores possam obter 0 máximo benefício econômico ao utilizarem esses fertilizantes.

Adubações sucessivas com fertilizantes amoniacais em cobertura têm aumentado a acidez da camada superficial do solo, principalmente em áreas de muitos anos de adoção do SPD (BARBOSA FILHO et al., 2001). A calagem, muitas vezes, se faz necessária nessas condições, mas pode haver interação do calcário com o nitrogênio na superfície do solo, reduzindo, assim, ainda mais a eficiência da adubação, e refletindo negativamente na produtividade das culturas. Howard e Essington (1998), por exemplo, relataram diminuição de $12 \%$ da eficiência da uréia aplicada em superfície devida à calagem.

No Brasil o cultivo de grãos é realizado basicamente em dois sistemas, plantio convencional (PC) onde o solo é revolvido com arados e/ou grades ou em semeadura direita (SD), comumente denominada sistema plantio direto (SPD), onde a semeadura é realizada no solo coberto com resíduos vegetais de culturas anteriores, adubos verdes e/ou resíduos de plantas daninhas. A 
expansão da área cultivada em SD foi bastante expressiva nos últimos anos, atingindo no ano agrícola 2004/05 cerca de 95.757 .000 milhões de hectares no mundo. No Brasil o SD alcançou na safra 2005/06 cerca de 25.501.656 milhões de hectares, ocupando a segunda maior área do mundo (FEBRAPDP, 2007). A importância da busca por novas fontes de fertilizantes nitrogenados e/ou misturas de fontes assim, a adubação nitrogenada na forma de uréia, está sujeita a maiores perdas de $\mathrm{NH}_{3}$ por volatilização, nesse sentido a eficiência de diferentes fontes nitrogenadas além da associação da uréia com outros fertilizantes o FASN é uma mistura adequada no sentido de controlar as perdas de $\mathrm{N}$ por volatilização, para definir técnicas de manejo para melhorar o uso da adubação na área definida.

O enxofre é um nutriente essencial para as plantas situando-se no grupo dos macronutrientes, como nitrogênio, fósforo, potássio, sendo que algumas culturas demandam mais enxofre do que fósforo. No solo, cerca de $90 \%$ do enxofre encontra-se na forma orgânica. Em grande parte dos solos brasileiros há deficiência de enxofre, principalmente em regiões de baixo teor de matéria orgânica.

Neste contexto o presente trabalho teve como objetivo avaliar a eficiência de utilização de fontes de nitrogênio e enxofre na composição química-bromatológica, e algumas características produtivas da cultura de milho (Zea mays L.), no sistema de plantio direto (SPD). 


\section{REVISÃO DA LITERATURA}

\subsection{Aspectos principais da cultura do milho}

O milho é uma planta de ciclo variado, que evidencia desde cultivares extremamente precoces, cuja polinização pode ocorrer em 30 dias após a emergência, até àquelas que demoram 300 dias para serem polinizadas. Nas condições brasileiras, o milho apresenta um ciclo variável de 110 dias a 180 dias, a partir do qual, os híbridos e cultivares são classificados como superprecoce, precoce, normal ou tardio, com base no período entre a emergência e o florescimento. O ciclo do milho é dividido em 11 estádios para facilitar o manejo e as pesquisas, bem como objetivar o estabelecimento de correlações entre elementos fisiológicos, climatológicos, fitogenéticos, entomológicos e fitotécnicos com o desempenho da planta.

Os estádios descritos a seguir foram adaptados de Hanway (1966) e de Nel e Smit (1978) por Fancelli (1986): (i) estádio 0 (semeadura à emergência); (ii) estádio 1 (planta com 4 folhas); (iii) estádio 2 (planta com 8 folhas); (iv) estádio 3 (planta com 12 folhas); (v) estádio 4 (emissão do pendão); (vi) estádio 5 (florescimento e polinização); (vii) estádio 6 (grãos leitosos); estádio 7 (grãos pastosos); (ix) estádio 8 (inicio da formação de grãos); (x) estádio 9 (grãos duros); e (xi) estádio 10 (grãos maduros).

O milho (Zea mays L.), originário da América, mais provavelmente na região onde situa-se o México, representa uns dos principais cereais cultivados e consumido no mundo, em virtude do seu alto potencial produtivo, composição química e valor nutritivo. Este cereal assume grande importância social e econômica, principalmente pela geração de empregos na zona rural e urbana, e por fornecer produtos largamente utilizados na alimentação humana, tanto na forma "in natural" como processado, e para a alimentação animal, representando o principal insumo para a confecção de rações. Alem disso, o milho e seus derivados constituem-se em matéria-prima para vários segmentos da industría, como por exemplo, farmacêutica, têxtil, bebidas, cosméticos, papeis, curtumes, colas dentre outras. 
Apesar o Brasil ser o terceiro maior produtor mundial de milho, não tem sido auto-suficiente nos últimos anos, necessitando de importação desse cereal. São cultivados atualmente aproximadamente 14,309 milhões de hectares com o milho, destacando-se, entre os grãos, como o segundo em maior volume produzido e valor da produção, sendo superado apenas pela soja. A produtividade média de grãos de milho no Brasil e no Estado de São Paulo, no ano agrícola 2006/2007, foi da ordem de $3.240 \mathrm{~kg} \mathrm{ha}^{-1}$, respectivamente (CONAB, 2008), podendo ser considerada baixa comparada a de outros países como a dos EUA $\left(\sim 7.000 \mathrm{~kg} \mathrm{ha}^{-1}\right)$ e da Argentina $(\sim 5.000 \mathrm{~kg}$ $\mathrm{ha}^{-1}$ ) e pelo potencial produtivo da cultura que é superior a $16.000 \mathrm{~kg} \mathrm{ha}^{-1}$ (Coelho et al., 2003). Dentre os principais fatores que contribui para a baixa produtividade média de milho no país, destacam-se: condições climáticas desfavoráveis de algumas regiões, utilização de variedades ou híbridos não adaptados a determinadas condições edafoclimáticas, uso de sementes não fiscalizadas e o manejo incorreto de corretivos e/ou de fertilizantes, principalmente dos nitrogenados, condicionando um baixo aproveitamento do $\mathrm{N}$ pela cultura.

Dentre as principais cultura de cereais dos trópicos sub-úmidos e semiáridos, o milho tem a mais alta produtividade em condições adequadas de água, luz e nutrientes minerais, com destaque para o $\mathrm{N}$, que é o nutriente mineral absorvido em maior quantidade e essencial para o crescimento e desenvolvimento da planta. Por ser constituinte de moléculas de proteína, enzimas, ácidos nucléicos e citrocromos, além de ser integrante da molécula de clorofila, atua diretamente no processo de divisão e expansão celular (Bull, 1993). Dessa forma, a deficiência de $\mathrm{N}$ proporciona a diminuição do índice de área foliar e da duração de folhas metabolicamente ativas (folhas verdes). Este fator repercute diretamente sobre a quantidade de radiação interceptada pela planta (fotossíntese), na produção de matéria seca e conseqüentemente sobre o rendimento de grãos. Contudo, o efeito sobre essas variáveis depende do grau e estádio fenológico em que ocorre a deficiência (Uhart \& Andrade, 1995).

A produtividade da cultura do milho está estritamente relacionada com a translocação de açúcares (Bull, 1993) e de N (Karlen et al., 1988) de órgãos vegetativos, principalmente das folhas, para os órgãos. Por outro lado, o aumento na produtividade de grãos proporcionado pelo $\mathrm{N}$ pode ser atribuído, 
também, aos efeitos sobre o crescimento do sistema radicular, aumento do comprimento espiga e do número de espigas por planta (Francelli \& Dourado Neto, 2000; Aita et al., 2001).

O nitrogênio (N) é essencial para o crescimento das plantas, sendo exigido em grandes quantidades para possibilitar o crescimento normal dos vegetais. Mediante deficiência de nitrogênio, as plantas apresentam sintomas típicos, como clorose de folhas velhas em função de quantidades reduzidas de clorofila, além de redução no crescimento (Melgar et al., 1999). No que se refere à exigência pelas culturas, de modo geral, o $\mathrm{N}$ é o nutriente mineral exigido em maior quantidade. Esse fato é refletido no consumo mundial do elemento em fertilizantes, superando as quantidades utilizadas de fósforo ou potássio (Raij, 1991). Por ser exigido em grandes quantidades pelas culturas e por apresentar elevado custo de obtenção, o N, junto com o fósforo $(P)$ e 0 potássio $(\mathrm{K})$, é denominado macronutriente primário ou nobre. Entretanto, $\mathrm{O}$ custo de obtenção de $\mathrm{N}$ é praticamente cinco vezes maior do que o custo de obtenção de P e oito vezes maior do que o custo de obtenção do K (Vitti et al., 2001).

\subsection{Características das principais fontes nitrogenadas}

Quantidades baixas encontram-se em rochas e minerais que formaram os solos (Melgar et al., 1999). Devido à alta solubilidade e instabilidade química dos compostos nitrogenados minerais, o $\mathrm{N}$ não figura como constituinte de rochas terrestres, pois é facilmente lavado. A ocorrência de nitrogênio em rochas é verificada somente em certas regiões áridas do Chile, Bolívia, e Peru onde é encontrado como salitre do Chile $\left(\mathrm{NaNO}_{3}\right)$, ou nos desertos da Índia e Egito, onde é encontrado como salitre de Bengala $\left(\mathrm{KNO}_{3}\right)$ (Vitti et al., 1984).

Quase todo $\mathrm{N}$ do solo provém da atmosfera, que contém reserva inesgotável desse elemento, porém, o N atmosférico está como gás inerte que deve combinar-se com outros elementos antes que as plantas possam usá-lo (Melgar et al., 1999). Segundo Epstein (1975), a principal fonte de $\mathrm{N}$ é a atmosfera, que possui $78 \%$ desse elemento em volume, na forma de gás inerte $\left(\mathrm{N}_{2}\right)$. Para possibilitar o uso do $\mathrm{N}$ na agricultura, há necessidade de fixação, 
que pode ocorrer por meio de processos biológicos e/ou industriais. Além dos processos de fixação, existe, a possibilidade do uso de resíduos orgânicos como fonte de N. No solo, o nitrogênio pode estar na forma mineral ou orgânica e a quantidade de $\mathrm{N}$ orgânico é maior em relação à quantidade de $\mathrm{N}$ inorgânico (Melgar et al, 1999). Entretanto, existe grande número de processos que resultam em transformações das formas orgânicas em inorgânicas e viceversa, e que podem redundar em ganhos ou perdas do sistema como um todo (Raij, 1991). Os mecanismos de adição de nitrogênio ao solo podem ser resumidos em fixação biológica, adição de matéria orgânica, aplicação de fertilizantes orgânicos ou minerais e adições pelas águas pluviais. Já os mecanismos de perda de nitrogênio do solo podem ser resumidos em remoção pelas colheitas, lixiviação, erosão e volatilização (Melo, 1978).

O manejo adequado do $\mathrm{N}$ na agricultura é fundamental para que não haja prejuízos na relação custo/beneficio, para o meio ambiente e para a nutrição das plantas. Considerando que o $\mathrm{N}$ é o elemento mais utilizado, extraído, e exportado pelas culturas, sendo o mais empregado na adubação e, considerado, ainda, que sua dinâmica no solo é muito intensa, envolvendo processos de adição e perda, reforça-se a necessidade de estudos que viabilizem o manejo adequado da adubação nitrogenada nos diferentes sistemas de cultivo.

A uréia $\left[\mathrm{CO}\left(\mathrm{NH}_{2}\right)_{2}\right]$ é caracterizada como fertilizante sólido granulado de maior concentração de N (45\%) que está na forma amídica. Dentre as vantagens da uréia, além da elevada concentração de $\mathrm{N}$, pode-se mencionar o menor custo com transporte, armazenamento e aplicação, alta solubilidade, baixa corrosividade e facilidade de misturas com outras fontes. (Melgar et al., 1999). A aplicação da uréia, na superfície do solo, pode causar perdas de $\mathrm{N}$ por volatilização de $\mathrm{NH}_{3}$ (Terman, 1979). A causa disso tem sido atribuída à ocorrência de chuvas logo após a aplicação do adubo e outras condições climáticas que evitam a ocorrência de perdas.

Como desvantagem da uréia, ressalta-se sua elevada higroscopicidade e maior susceptibilidade à volatilização. Se houver umidade, ocorre determinação e dissolução do grânulo de uréia aplicado ao solo. Ao entrar em contato com a urease presente no solo em resíduos vegetais, a uréia sofre hidrólise, produzindo carbonato de amônio $\left.\left[\mathrm{NH}_{4}\right)_{2} \mathrm{CO}_{3}\right]$. $\mathrm{O}$ acúmulo de 
carbonato de amônio causa aumento do $\mathrm{pH}$ e esse evento pode ser acompanhado pela emissão de $\mathrm{NH}_{3}$ (Melgar et al., 1999).

O sulfato de amônio $\left.\left[\mathrm{NH}_{4}\right)_{2} \mathrm{SO}_{4}\right]$ é uma fonte de $\mathrm{N}$ que, mundialmente, tem sido menos utilizada que a uréia, o nitrato de amônio e o uran (Byrnes, 2000). Sua produção dá-se a partir de subprodutos da indústria (aço, metalúrgica, produção de nylon), sendo a caprolactama (subproduto da indústria de nylon) importante fonte para sua produção. A partir de uma tonelada de caprolactama é possível obter até quatro toneladas de sulfato de amônio. Também é possível obter sulfato de amônio através de sínteses directa $\left(\mathrm{NH}_{3}+\mathrm{H}_{2} \mathrm{SO}_{4}\right)$, entretanto essa forma de obtenção não é tão viável como a citada anteriormente (Monesmith, 2001). Dentre as principais vantagens do sulfato de amônio, sita-se sua baixa higroscopicidade, boas propriedades físicas, estabilidade química, boas características agronômicas, potencial de oferta de enxofre (24\%), além do N (21\%) (Byrnes, 2000).

Alguns autores mencionam que, como desvantagem, o sulfato apresenta no solo uma reação fortemente ácida, fato esse que, em solos de regiões tropicais pode tornar-se problemático (Kunz, 2001). Além disso, possui apenas $21 \%$ de N, aumentando o custo de aplicação, estocagem e transporte, de maneira tal que, o custo por unidade de $\mathrm{N}$ seja bem maior em relação à uréia. Por outro lado, o uso do sulfato de amônio será considerado vantajoso se o custo de obtenção for baixo, a distância de transporte for curta e se a fonte for empregada como objetivo de fornecer S, além do N (Byrnes, 2000).

A mistura de uréia com sulfato de amônio apresenta boa eficiência agronômica, com menores taxas de volatilização devido à menor quantidade de $\mathrm{N}$ da uréia, bem como pelo efeito acidificante do sulfato de amônio (Vitti, 2001b). O entendimento da forma pela qual a mistura possibilita redução na volatilização é facilitado pelas equações químicas a seguir:

Urease

1) $1\left[\mathrm{CO}\left(\mathrm{NH}_{2}\right)_{2}\right]+2 \mathrm{H}_{2} \mathrm{O} \longrightarrow 1\left(\mathrm{NH}_{4}\right)_{2} \mathrm{CO}_{3}$

2) $1\left(\mathrm{NH}_{4}\right)_{2} \mathrm{CO}_{3} \longrightarrow 2 \mathrm{NH}_{3}+1 \mathrm{H}_{2} \mathrm{CO}_{3}$ 
3) $\mathrm{H}_{2} \mathrm{CO}_{3} \longrightarrow 1 \mathrm{CO}_{2}+\mathrm{H}_{2} \mathrm{O}$

4) $1 \mathrm{NH}_{3}+\mathrm{H}_{2} \mathrm{O} \longrightarrow 1 \mathrm{NH}_{4}^{+}+1 \mathrm{OH}^{-}$

5) $1\left(\mathrm{NH}_{4}\right)_{2} \mathrm{SO}_{4} \longrightarrow 2 \mathrm{NH}_{4}{ }^{+}+1 \mathrm{SO}_{4}^{-2}$

6) $2 \mathrm{NH}_{4}^{+}+3 \mathrm{O}_{2} \longrightarrow 2 \mathrm{NO}_{2}^{-}+4 \mathrm{H}^{+}+2 \mathrm{H}_{2} \mathrm{O}$

Como conseqüência do uso da mistura, tem-se:

2) $\mathrm{H}^{+}$(reação 6) $+\mathrm{OH}^{-}$(reação 4) $\longrightarrow \mathrm{H}_{2} \mathrm{O}$

Vitti et al. (2001b) estudaram o efeito da adição de sulfato de amônio em mistura com uréia sobre a volatilização de $\mathrm{N}-\mathrm{NH}_{3}$, assumindo a hipótese de que, devido à redução da forma amídica de $\mathrm{N}$ e ao efeito acidificante do sulfato de amônio, a mistura proporcionaria menores taxas de volatilização. Ao misturar uréia e sulfato de amônio nas proporções de $50 \%$ e $50 \%$, os autores observaram menores perdas de $\mathrm{N}-\mathrm{NH}_{3}$ por volatilização.

Os resíduos orgânicos também são considerados importantes fontes de nitrogênio. A matéria orgânica pode tornar-se nitrogênio e outros nutrientes. Como definição tem-se que substância orgânica é aquela constituída por tetracovalente com ligações completadas por átomos de hidrogênio, oxigênio, nitrogênio, enxofre, dentre outros. Vegetais e animais apresentam em sua composição substâncias orgânicas de natureza diversa. Admite-se que os tecidos vegetais são constituídos por carboidratos (1 a 5\% de açúcares e amido, 10 a $28 \%$ de hemicelulose e 20 a $50 \%$ de celulose), 1,8\% de gorduras, ceras e taninos 10 a 30\% de ligninas e 1 a 15\% de proteínas (Melo, 1978).

Segundo Oliveira (1987), a decomposição da matéria orgânica do solo é fundamental para o desenvolvimento vegetal, mediante esse processo ocorre 0 fornecimento de macro e micronutrientes para as plantas. Da decomposição de resíduos orgânicos entre outros no solo, resulta na liberação para os vegetais 
de $\mathrm{N}, \mathrm{P}, \mathrm{K}$ e $\mathrm{S}$, o processo que converte as formas orgânicas de $\mathrm{N}$ à formas inorgânicas denomina-se mineralização e ocorre à medida que os microrganismos do solo decompõem a matéria orgânica para obter energia. As diferentes fases que envolvem as transformações do $\mathrm{N}$ no solo são da seguinte forma:

a) Amonificação

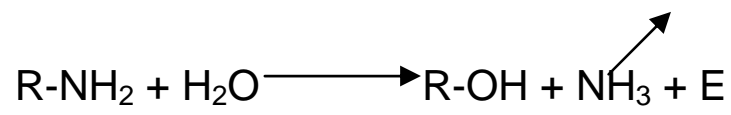

$\mathrm{NH}_{3}+\mathrm{H}_{2} \mathrm{O} \rightleftarrows \mathrm{NH}^{+}+\mathrm{OH}^{-}$

b) Nitrificação

b1) Nitritação

Nitrosomonas

${ }_{2} \mathrm{NH}_{4}{ }^{+}+{ }_{3} \mathrm{O}_{2} \longrightarrow 2 \mathrm{NO}_{2}^{-}+{ }_{2} \mathrm{H}_{2} \mathrm{O}+4 \mathrm{H}^{+}+\mathrm{E}$

b2) Nitratação

Nitrobacter

$2 \mathrm{NO}_{2}^{-}+\mathrm{O}_{2} \longrightarrow 2 \mathrm{NO}_{3}^{-}+\mathrm{E}$

Após a amonificação, o primeiro produto resultante da decomposição da matéria orgânica é o amônio $\left(\mathrm{NH}_{4}{ }^{+}\right)$, proveniente da decomposição de proteínas, aminoácidos e outros compostos. Em condições favoráveis para o crescimento das plantas, a maior parte do $\mathrm{NH}_{4}{ }^{+}$do solo se converte em nitrato $\left(\mathrm{NO}_{3}{ }^{-}\right)$pela ação de bactérias nitrificantes. Esse processo denomina-se nitrificação e produz acidez no solo devido à liberação de íons $\mathrm{H}^{+}$(Melgar et al., 1999). Além dos processos citados, também é importante mencionar a 
desnitrificação. $\mathrm{N}_{2} \mathrm{O}$ e $\mathrm{N}_{2}$. Os gases resultantes da desnitrificação são liberados para a atmosfera e, junto ao dióxido e monóxido de carbono e o metano, são considerado gases de efeito estufa. Mediante anaerobiose e presença de microrganismos anaeróbios facultativos ou obrigatórios, ocorre a desnitrificação. O cultivo dos solos sem adição de resíduos orgânicos propicia, em geral, redução nos teores de matéria orgânica com o passar dos anos. Essa redução pode ser favorecida pela prática de queimadas e pelo revolvimento do solo. Assim, ocorre queda exponencial do teor total de nitrogênio no solo, mais rápida no início e em proporção cada vez menor com o passar do tempo, até que seja atingido novo teor de equilíbrio, o que pode demorar muitas décadas para acontecer (Raij, 1991).

Com os sistemas de cultivo que envolve manutenção de palha na superfície do solo, o acúmulo de matéria orgânica é favorecido. O resíduo vegetal remanescente no solo atua como fonte potencial de nitrogênio, enxofre e outros nutrientes para as culturas (Furlani Neto, 1997; Gava, 1999) e preciso sofrer mineralização para que os nutrientes nele contidos sejam disponibilizados para as plantas. Wood (1991) verificou elevação do teor de carbono orgânico de 0,6\% a 1\%, e do N-total de 0,06 a 0,08\% na camada de $10 \mathrm{~cm}$ de solo, após cinco anos de cultivo com presença de palha. Dependendo da composição de resíduo vegetal a taxa de mineralização durante o ano agrícola pode ser muito baixa (Melo, 1978; Kiehl, 1987). Vitti (1998) relatou que a adição ao solo de resíduos vegetais na cultura de milho com elevada relação $\mathrm{C} / \mathrm{N}$, provocou imobilização líquida da fonte nitrogenada aplicada. Weng e Li (1992) constataram imobilização biológica do N mediante uso de resíduos com elevada relação $\mathrm{C} / \mathrm{N}$.

Em função da relação $\mathrm{C} / \mathrm{N}$ do resíduo vegetal, pode ocorrer mineralização ou imobilização dos nutrientes através da ação de microrganismos. Se a relação $C / N$ do resíduo é elevada (>30:1), microrganismos possuem sobra de energia e assimilam todo $\mathrm{N}$ mineral que passa a ser orgânico, ficando temporariamente indisponível ás plantas. Mediante redução na relação $\mathrm{C} / \mathrm{N}$, em determinado momento há diminuição na oferta de energia para os microrganismos e estes sofrem decomposição, liberando o $\mathrm{N}$ que estava assimilado em suas estruturas. Ao adicionar-se $\mathrm{N}$ 
mineral em solo com resíduo com elevada relação $\mathrm{C} / \mathrm{N}$, inicialmente ocorre competição entre as raízes das plantas e os microrganismos do solo pelo $\mathrm{N}$ aplicado (Kiehl, 1987; Jingguo \& Bakken, 1997).

Sabe-se que resíduos orgânicos depositados na superfície do solo são fontes potenciais de nutrientes, principalmente nitrogênio. Entretanto, com os processos de mineralização e imobilização e com toda complexa dinâmica de $\mathrm{N}$, fica difícil avaliar precisamente a disponibilidade desse nutriente nos diferentes resíduos vegetais (Oliveira, 1987).

\subsection{Manejo do solo e recomendação de adubação nitrogenada para milho}

O nitrogênio $(\mathrm{N})$ é um nutriente mineral que pode ser absorvido pelas plantas em duas formas distintas como, ânion $\left(\mathrm{NO}_{3}{ }^{-}\right)$e cátion $\left(\mathrm{NH}_{4}{ }^{+}\right)$. A planta de milho utiliza, predominantemente, o íon amônio $\left(\mathrm{NH}_{4}{ }^{+}\right)$nos estádios iniciais de crescimento e desenvolvimento, enquanto a forma nítrica $\left(\mathrm{NO}_{3}{ }^{-}\right)$é absorvida mais intensamente nos estádios finais do ciclo (WARNCKE, BARBER, 1973). Segundo Below (1995), independentemente da forma absorvida, o N é incorporado em numerosos compostos orgânicos essenciais à planta. Embora, o metabolismo do $\mathrm{N}$ em relação ao crescimento e rendimento da planta seja complexo, é possível resumí-lo em duas funções básicas, como: (i) manutenção da capacidade fotossintética, em particular, pela participação do $\mathrm{N}$ na molécula de clorofila (ii) pelo estimulo ao crescimento e desenvolvimento de drenos reprodutivos.

No Brasil, a aplicação de nitrogênio na cultura de milho, tradicionalmente, é junto de modo parcelado com uma dose na semeadura que, geralmente, varia de $60 \mathrm{~kg} \mathrm{ha}^{-1}$ a $30 \mathrm{~kg} \mathrm{ha}^{-1}$, e o restante em cobertura nos estádios de seis folhas a oito folhas. O parcelamento reduz o excesso de sais no sulco de plantio e o risco de prejuízo à geminação; atenua a perda de nitrato por lixiviação (COELHO et al., 2003); estimula a formação de raízes alimentadoras (pêlos absorventes), bem como o crescimento da parte aérea; e, favorece a diferenciação dos primórdios da panícula e da espiga no estádio de 
4 folhas, época em que a planta define o potencial de produção (FANCELLI, 1997).

O nitrogênio é o principal nutriente na cultura de milho, altamente limitante à produtividade de grãos (BALKO; RUSSEL, 1980). Ferreira et al. (1996) observaram aumentos significativos na produção de milho em razão do incremento das doses de nitrogênio. Neptune et al. (1982) obtiveram resultados semelhantes quando verificaram aumentos médio, da ordem de três a sete vezes, na produtividade de milho no Estado de São Paulo (1.200 kg ha $\left.{ }^{-1}\right)$, pela aplicação de doses crescentes desse nutriente $(\mathrm{N})$.

O aumento da produtividade proporcionado pelo nitrogênio, também pode ser atribuído aos efeitos promovidos sobre o crescimento radicular, a aumento do cumprimento da espiga, a número de espigas por plantas, bem como o número de grãos por espiga (BALKO; RUSSEL, 1980). De acordo com Yamada (1997) o nitrogênio e o potássio são os nutrientes absorvidos em maiores quantidades pelo milho, aproximadamente, $190 \mathrm{~kg} \mathrm{ha}^{-1}$ de $\mathrm{N}$ e $230 \mathrm{~kg}$ $\mathrm{ha}^{-1}$ de $\mathrm{K}_{2} \mathrm{O}$. Observa-se a obtenção de rendimentos da ordem de $9.500 \mathrm{~kg} \mathrm{ha}^{-1}$ a partir do fornecimento de $40 \mathrm{~kg} \mathrm{ha}^{-1}$ de $\mathrm{N}$ na semeadura, complementados com a adição de $80 \mathrm{~kg} \mathrm{ha}^{-1}$ a $100 \mathrm{~kg} \mathrm{ha}^{-1}$ em cobertura, no estádio V4.

De maneira geral, recomenda-se a aplicação de $40 \mathrm{~kg} \mathrm{ha}^{-1}$ a $50 \mathrm{~kg} \mathrm{ha-1}$ de N no plantio (FANCELLI; DOURADO NETTO, 1996; YAMADA; ABDALLA, 2000), e o restante em cobertura, num total de aproximadamente, $120 \mathrm{~kg} \mathrm{ha}^{-1}$ a $150 \mathrm{~kg} \mathrm{ha}^{-1}$. Duarte (2003) verificou em seu trabalho, diferenças entre as culturas em relação à resposta à aplicação de nitrogênio em cobertura, assim como variação no padrão de exigências de $\mathrm{N}$ nos estádios iniciais de crescimento, bem como a ausência de resposta à aplicação de $\mathrm{N}$ (plantio e cobertura) para doses superior a $120 \mathrm{~kg} \mathrm{ha}^{-1}$.

Portanto, embora existam inúmeros trabalhos de pesquisa referentes à resposta da cultura do milho ás doses de nitrogênio, a interpretação desses resultados exige que sejam considerados alguns fatores como: responsividade do material genético, condições edafoclimáticas, sistema de cultivo (sistema plantio direto e sistema convencional), época de semeadura (milho safra e safrinha), rotação de culturas, aspectos econômicos, operacionalização, época de aplicação, método de aplicação e fontes de nitrogênio empregadas. Isso 
tudo confirma a regra de que as recomendações de nitrogênio devem ser cada vez mais específicas e não generalizadas. (CRUZ; LARA CABEZAS, 2001).

A atmosfera possui aproximadamente $78 \%$ de nitrogênio, principalmente na forma de $\mathrm{N}_{2}$, é a fonte natural desse elemento para a biosfera. Apesar disso, o $\mathrm{N}_{2}$ é uma fonte natural gasosa e não diretamente aproveitada pelas plantas, para tal, há necessidade de uma transformação prévia para as formas combinadas $\mathrm{NH}_{4}^{+}$(amônio) e $\mathrm{NO}_{3}^{-}$(nitrato). Os processos pelo qual o $\mathrm{N}$ é adicionado ao solo, são a aplicação de adubos orgânicos ou minerais, a fixação biológica, a adição de matéria orgânica e o acréscimo de $\mathrm{N}$ pelas águas das chuvas (MELO, 1978; RAIJ, 1991).

Em virtude da multiplicidade de reações químicas e biológicas, dependência das condições edafoclimáticas, vulnerabilidade a perdas por lixiviação, volatilização, desnitrificação e erosão, quando manejado inadequadamente, e ao processo de imobilização biológica e do seu efeito no rendimento das culturas, o $\mathrm{N}$ é o elemento que apresenta maiores dificuldades de manejo e recomendação na produção agrícola (Camargo \& Sá, 2004; Cantarella \& Duarte, 2004). O N é o único dos nutrientes minerais que pode ser absorvido pelas plantas em duas formas distintas como: como amônio $\mathrm{NH}_{4}{ }^{+}$ou como $\mathrm{NO}_{3}{ }^{-}$cátion. Além de ser absorvido também como aminoácidos e uréia (Malavolta et al., 1997) e em pequena quantidade como $\mathrm{NH}_{3}$ presente na atmosfera (Francis et al., 1993).

Em alguns estados brasileiros, a dose de $\mathrm{N}$ recomendada para o milho é relacionada com os teores de MOS, o histórico da área, produtividade esperada, ao preço do fertilizante nitrogenado (Raij et al., 1996; Sousa \& Lobato, 2004) e também a cultura de cobertura antecessora (Amado et al., 2002).

A utilização da analise de $\mathrm{N}$ mineral no solo $\left(\mathrm{NH}_{4}{ }^{+}\right.$e $\left.\mathrm{NO}_{3}\right)$ para a recomendação de $\mathrm{N}$ é uma técnica limitada por diversos fatores como exemplo, um método que possa ser incorporado na rotina de laboratórios de solo, critérios de amostragem no campo e passividade de transformações que o $\mathrm{N}$ pode sofrer da coleta da amostra até a chegada ao laboratório, alta variabilidade espacial e temporal, proporcionando baixa correlação com as respostas pelas culturas. Estes métodos de analises são empregados em pequena escala por alguns países de condições climáticas bem definidas e 
regiões de clima árido, nas quais as perdas por lixiviação são pequenas principalmente, para medir o $N$ residual no solo (Keeney, 1982) e auxiliar na tomada de decisão da dose de $\mathrm{N}$ a ser aplicada na cultura subseqüente. Este método praticamente não é aplicado para a recomendação de $\mathrm{N}$ para o milho no Brasil.

O aumento na dose aplicada de $\mathrm{N}$, na maioria das vezes, proporciona aumento no rendimento da cultura do milho (Duarte, 2003; Cantarella \& Duarte, 2004). De acordo com Yamada (1995), a adubação nitrogenada no SPD tem boa probabilidade de respostas ao uso de 40 a $50 \mathrm{~kg} \mathrm{ha}^{-1}$ de $\mathrm{N}$ na semeadura, com cobertura nitrogenada feita logo após a semeadura, sendo recomendável uma segunda cobertura em solos de textura mais arenosa.

Recentemente, Sousa \& Lobato (2004) propuseram a recomendação do $\mathrm{N}$ para o milho, considerando-se a produtividade esperada, o teor de MOS, as últimas três culturas antecessoras e suas respectivas produtividades de grãos e a eficiência de utilização do $N$ fertilizante pelo milho.

Os autores recomendam aplicar $30 \mathrm{~kg} \mathrm{ha}^{-1}$ de $\mathrm{N}$ na semeadura e $\mathrm{o}$ restante, quando inferior a $100 \mathrm{~kg} \mathrm{ha}^{-1}$ de $\mathrm{N}$, no estádio de 7 a 8 folhas para 0 PC e 4 a 6 folhas para SPD. A eficiência de utilização do $N$ tem alta dependência da forma de manejo e das condições edafoclimáticas, sendo que as maiorias das pesquisas indicam que raramente ultrapassa $50 \%$ do $\mathrm{N}$ do fertilizante aplicado (Scivittaro et al., 2000). Por tanto, considerar a eficiência de $60 \%$ pode induzir a uma subestimativa da dose necessária que provavelmente, não vai poder ser suprida pelo solo, pois no cálculo de recomendação já inclui o $\mathrm{N}$ mineralizado da MOS e o $\mathrm{N}$ proveniente da mineralização dos resíduos culturais.

Atualmente, a recomendação de $N$ para a cultura do milho em SPD para os Estados do Rio Grande do Sul e de Santa Catarina é feita levando-se em consideração, além do teor de MOS e a expectativa de produtividade de grãos (CFS-RS/SC, 1995), o tipo de cobertura antecessora a cultura considerandose para isso três situações: leguminosa em cultivo solteiro, gramínea em cultivo solteiro e consorciações de gramíneas e leguminosas. A contribuição no fornecimento de $\mathrm{N}$ para o milho pelas leguminosas é calculada em função da quantidade da matéria seca produzida; para as gramíneas este é considerado como muito pequeno ou nulo em relação ao pousio invernal, especialmente 
para situações de elevada produção de matéria seca, por causa do decréscimo na disponibilidade de $\mathrm{N}$ pela imobilização microbiana. Além disso, quando o milho é cultivado em rotação com a soja, recomenda-se reduzir a dose de $\mathrm{N}$ em 20\% (Amado et al., 2002).

No Estado de Minas Gerais a recomendação de $\mathrm{N}$ é feita em função do rendimento de grãos esperado, aplicando-se de 10 a $20 \mathrm{~kg} \mathrm{ha}^{-1}$ de $\mathrm{N}$ na semeadura para PC e $30 \mathrm{~kg} \mathrm{ha}^{-1}$ de $\mathrm{N}$ para SPD. Em cobertura, a recomendação é de $60 \mathrm{~kg} \mathrm{ha}^{-1}$ de $\mathrm{N}$ para uma faixa de produtividade de quatro a seis toneladas por hectare, $100 \mathrm{~kg} \mathrm{ha}^{-1}$ de $\mathrm{N}$ para seis a oito toneladas por hectare e de $140 \mathrm{~kg} \mathrm{ha}^{-1}$ de $\mathrm{N}$ para expectativas acima de oito toneladas de grãos. No milho cultivado em sucessão à soja, recomenda-se reduzir 20 kg ha${ }^{1}$ de $\mathrm{N}$ (Alves et al., 1999).

Mascarenhas et al. (1983), em experimento conduzido em áreas com um a quatro anos de cultivo da soja verificaram efeito positivo sobre a produtividade de grãos de milho. Esse efeito foi diretamente proporcional ao tempo de cultivo da soja, sendo que cada ano correspondeu a produção de milho com a aplicação de $17,3 \mathrm{~kg} \mathrm{ha}^{-1}$ de $\mathrm{N}$.

No estado de São Paulo, além da expectativa de rendimento, a recomendação de $\mathrm{N}$ para o milho estabelece classes de respostas, baseadas principalmente no histórico de uso e manejo da área como, por exemplo, o tempo de adoção da SPD, cultivo de gramíneas, aplicação de adubos orgânicos, cultivos de leguminosas, textura de solo, reação do solo e outras. Recomenda-se $20 \mathrm{~kg} \mathrm{ha-1}$ de $\mathrm{N}$ na semeadura para expectativa de produtividade de quatro a seis toneladas de grãos por hectare e $30 \mathrm{~kg} \mathrm{ha}^{-1} \mathrm{de}$ $\mathrm{N}$, para seis a doze toneladas de grãos por hectare. A adubação de cobertura varia de 20 a $140 \mathrm{~kg} \mathrm{ha}^{-1}$ de $\mathrm{N}$, em função da produtividade esperada e da classe de resposta esperada a $\mathrm{N}$, classificada como baixa, média ou alta (Raij et al. 1997). 
Nos EUA a recomendação de adubação de nitrogenada muito utilizada é a de 17,8 a $21,4 \mathrm{~kg} \mathrm{ha}^{-1}$ de $\mathrm{N}$ por tonelada de grãos a ser produzida (Sims et al., 1995). Esse valor é descontado da contribuição em $\mathrm{N}$ pela leguminosa cultivada anteriormente, $17 \mathrm{~kg} \mathrm{ha}^{-1}$ de $\mathrm{N}$ por tonelada de grãos de soja, até um máximo de $45 \mathrm{~kg} \mathrm{ha}^{-1}$ de $\mathrm{N}$, ou da aplicação de adubos orgânicos ou outras fontes de $\mathrm{N}$ (Below, 2002).

$\mathrm{Na}$ Argentina, país que vem se despontando na produtividade média (5000 km ha-1) de milho (Coelho. 2003), não foi observado grandes diferenças na resposta a N para a SPD e o PC (Echeverria et al., 2004). Assim, como verificado por Sims et. al. (1995) e Fox et al. (1986) nos EUA, algumas pesquisas na Argentina têm demonstrado também boas correlações entre 0 teor de $\mathrm{N}_{-} \mathrm{NO}_{3}$ na camada de 0 a 0,3 m, avaliado no estádio $\mathrm{V} 4$ a V6, com as doses de $\mathrm{N}$ aplicadas e a produtividade de grãos. Segundo Echeverria et al. (2004), nesse país a aplicação de pequenas quantidades de $\mathrm{N}$ na semeadura e a cobertura no estádio V5 a V6, tem proporcionado maior eficiência de utilização do $\mathrm{N}$ pelo milho, em virtude da redução nas perdas de $\mathrm{N}$ por lixiviação e desnitrificação e pela menor imobilização microbiana do $\mathrm{N}$. Contudo, para as condições brasileiras varias pesquisas já demonstraram que, apesar de serem relativamente pequenas as exigências de $\mathrm{N}$ na fase inicial de desenvolvimento, há grande resposta em produtividade de grãos em função de N aplicado na semeadura (Sá, 1996; Yamada. 1996; Silva et al., 1997; Amado et al., 2002). Isso, provavelmente deve-se à maior fertilidade e CTC dos solos argentino comparados à maioria dos solos brasileiros cultivados com milho, proporcionando maior fornecimento de $\mathrm{N}$ à cultura na fase inicial.

Devido ao não revolvimento do solo e manutenção dos resíduos vegetais na superfície, sob SPD ocorre alteração na dinâmica e na transformação das formas de $\mathrm{N}$ no solo (Amado et al., 2002). Na fase inicial da SPD observa-se a necessidade de aplicação de maiores quantidades de $\mathrm{N}$, devido à intensificação do processo de imobilização no solo pelos microrganismos quimiorganotróficos como resposta à maior oferta de carbono orgânico no sistema. Normalmente, após quatro anos, parece ocorrer o inicio do restabelecimento do equilíbrio da transformação no sistema, à medida que ocorre a reposição dos resíduos culturais (Sá. 1993). 
Dessa forma, uma proposta de recomendação de $\mathrm{N}$ deve ser dinâmica, incorporando novos resultados de pesquisa, sendo primordiais o conhecimento pelo técnico responsável do histórico da área e das produtividades obtidas. Outros aspectos que se deve ser considerado é o preço de mercado do fertilizante, o preço do milho e, apesar de difícil de serem previstos, os riscos climáticas, principalmente na segunda safra de milho (safrinha).

No Brasil tem surgido nos últimos anos pesquisas para diagnosticar a disponibilidade de $\mathrm{N}$ através da medição indireta da clorofila com a utilização do aparelho clorofilômetro (SPAD, Minota Co. Japão), onde uma leitura digital corresponde à quantidade de luz verde ou vermelha transmitida pela folha, que é correlacionada com a concentração de clorofila da folha (Malavolta et al., 1997).

Os solos dominantes no cerrados, notadamente os Latossolos, são, de modo geral, de textura argilosa, bem estruturada e com alta estabilidade de agregados. São solos altamente intemperizados, com baixa capacidade de troca de cátions (CTC) e altamente dependentes da matéria orgânica (GOEDERT, 1980). As limitações devidas à baixa CTC, bem com à baixa capacidade de água disponível, podem ser corrigidas ou amenizadas pelo aumento da matéria orgânica nos solos, utilizando rotação de culturas adequadas (YAMADA; ABDALLA, 2004). Devido a inúmeras vantagens comparativas a evolução do SPD, no que se refere a sua adoção por agricultores de todo o planeta, tem sido bastante representativo. Segundo Bartz (2006), a base de sustentação do SPD consiste, da não mobilização do solo, na adoção de rotação de culturas capazes de produzir e manter, por maior período de tempo, grande quantidade de massa vegetal na superfície do solo. Sendo assim, o plantio direto tem sido adotado considerando a sua eficiência na conservação dos recursos naturais solo e água, apresentando-se como uma alternativa viável em substituição ao sistema convencional.

Segundo Yamada e Abdalla (2004), a formação e a manutenção da cobertura morta nos solos tropicais, em especial nos Cerrados, foram alguns dos principais obstáculos encontrados para o estabelecimento do SPD, considerando-se que altas temperaturas associadas à adequada umidade promovem rápida decomposição dos resíduos vegetais mantido na superfície do terreno. Seguy; Bouzinac e Matsubara (1992) relataram que, no Estado de 
Mato Grosso, num período de 90 dias após a primeira chuva, as palhadas de milho, arroz e soja foram reduzidas, respectivamente, em $63 \%, 65 \%$ e $86 \%$ de sua massa inicial, nesta mesma ordem, aos 90 dias, promoveram cobertura de solo de 30\%, 38\% e 7\%. Silveira \& Stone (2001) relataram que independente do sistema de manejo do solo, inclusive no SPD, em 12 cultivos consecutivos, rotações envolvendo, arroz, feijão, milho, soja, trigo e arroz consorciado com calopogônio não alteraram o teor de matéria orgânica do solo. Entretanto, Kanno et al. (1999) consideraram a Brachiaria brizantha como a melhor opção a ser introduzida na rotação cultura-pastagem para melhorar a qualidade do solo, no que diz respeito à quantidade e distribuição de biomassa radicular.

Já Aidar et al. (2000), quando estudaram diferentes fontes de resíduos para cobertura morta, em Latossolo Roxo de alta fertilidade, na região do Brasil Central, verificaram que, dentre as principais culturas anuais, apenas os restos culturais do milho apresentaram um quantitativo suficiente, no que se refere à formação de cobertura morta.

O acúmulo de materiais orgânicos, em diferentes estágios de decomposição, nas camadas superficiais do solo, confere ao SPD inúmeras vantagens, quando comparado ao sistema convencional. Pode-se dizer que a interação dos efeitos físicos, químicos e biológicos do acúmulo superficial de materiais orgânicos, em estágios de decomposição, produz reflexos imediatos na conservação e ao longo dos anos, também na fertilidade do solo (BARTZ, 2006). Nesse sentindo, Sá (1996) observaram que até o quarto ano da implantação do SPD o caráter dreno da matéria orgânica do solo foi maior que o caráter fonte. O autor observou ainda que dependendo das condições edafoclimáticas e da seqüência estabelecida em rotação de culturas, após o quarto ano ocorreu reestabelecimento entre a demanda e a oferta de $\mathrm{N}$ no sistema. Mas somente após 9 a 12 anos da implantação ocorreu maior liberação de $\mathrm{N}$ no sistema. Em virtude disso, normalmente se recomenda para o manejo da adubação nitrogenada no SPD, principalmente fase inicial de adoção, doses de $\mathrm{N}$ de 10 a 30\% maiores que as aplicadas no plantio convencional (CERETTA; FRIES, 1998) e de no mínimo $30 \mathrm{~kg} \mathrm{ha}^{-1}$ de $\mathrm{N}$ na semeadura (SÁ, 1996).

Sabe-se que a dinâmica dos nutrientes é diferente nos sistemas sem preparo quando comparado com o preparo convencional, pois as condições 
criadas no ambiente pelo acúmulo de resíduos modificam a velocidade e a intensidade das reações que controlam a disponibilidade da maioria dos nutrientes, o que poderá influenciar o rendimento da cultura subseqüente.

Avaliando a resposta do milho ao fertilizante nitrogenado em SPD sobre diferentes adubos verdes Sá (1996) verificou que a maior dose de $N$ fertilizante na sucessão aveia preta/milho proporcionou o mesmo rendimento de grãos que uma dose menor de $\mathrm{N}$ fertilizante na sucessão ervilhaca/milho. Aidar et al. (2000), utilizando um Latossolo Roxo eutrófico, obtiveram melhores rendimentos de feijão, cv. Pérola, em palhadas de Brachiaria brizantha, arroz e Brachiaria ruziziensis, sendo o pior rendimento sobre a palhada de milho, atribuído ao seqüestro do $\mathrm{N}$ pela palhada. A seqüência de cullturas com predominância de gramíneas (alta relação $\mathrm{C} / \mathrm{N}$ ) pode, ao menos nos primeiros anos do SPD acarretar queda significativa na produtividade do milho, a menos que se realize a adubação nitrogenada para balancear essa relação (RIZZARDI, 1995).

\subsection{Perdas e eficiência do uso do nitrogênio pelo milho}

A dinâmica do $\mathrm{N}$ no sistema solo planta e, conseqüente eficiência de sua utilização pela planta, é condicionada principalmente pelo sistema de cultivo, formas de manejo do $\mathrm{N}$ e condições edafoclimáticas (Kitur et al., 1984; Meisinger et al., 1985; Amado et al., 2002). Normalmente grande parte do $\mathrm{N}$ aplicado não é utilizado pela cultura do milho (Lara Cabezas et al., 2000; Scivittaro et al., 2003), e o uso de uma fonte marcada com ${ }^{15} \mathrm{~N}$ constitui-se no único método que permite quantificar com maior precisão a eficiência de utilização desse nutriente (Mohammed et al., 1995) e possibilita também quantificar a contribuição do N proveniente do solo (Timmons \& Baker, 1992; Elabbadi et al., 1996).

A maioria dos trabalhos demonstram que existe uma grande variação no aproveitamento do $\mathrm{N}$ do fertilizante pelo milho, que raramente ultrapassa $50 \%$ do aplicado como fertilizante orgânico (Scivittaro et al., 2000) e 20\% de fontes orgânicos no caso de adubos verdes (Azam et al., 1985; Ambrosano, 1995; Muraoka et al., 2002). Essas diferenças ocorrem em função de diversos fatores 
destacando-se as condições edafoclimáticas, o tipo de fertilizante e o sistema de cultivo (Meisinger et al., 1985; Lara Cabezas, et al., 2000). Estudos com milho cultivado em SPD foram encontrados diferentes valores de eficiência de utilização do $\mathrm{N}$ do fertilizante 46\% (Kitur et al., 1984; 10\% (Timmons \& Cruse, 1990); 42\% (Timmons \& Baker, 1992); 30\% (Lara Cabezas et al., 2000); 37\% (Gava, 2003); 48\% para o N aplicado em pré-semeadura e $66 \%$ para o $\mathrm{N}$ aplicado em cobertura (Cantarella et al., 2003) e 40,4\% para o $\mathrm{N}$ aplicado em pré-semeadura e $79,2 \%$ para o $\mathrm{N}$ aplicado em cobertura (Campos, 2005). De maneira geral, as médias de aproveitamento do $\mathrm{N}$ do fertilizante, nos estudos citados anteriormente, foram de $43 \%$ para a planta toda e $28 \%$ para os grãos. Isto equivale ao acúmulo de aproximadamente $65 \%$ do $\mathrm{N}$ proveniente do fertilizante nos grãos e $35 \%$ nas demais partes da planta.

Coelho et al. (1991), avaliando o balanço de $\mathrm{N}$ na cultura do milho com aplicação de $60 \mathrm{~kg}$ ha-1 de ${ }^{15} \mathrm{~N}$-uréia, obtiveram eficiência de utilização do fertilizante de $56 \%$. Na camada de solo de 0 a $90 \mathrm{~cm}$ de profundidade, permaneceram $23 \%$ do $\mathrm{N}$ do fertilizante, sendo que $15 \%$ foram perdidos do sistema. Ulhoa et al. (1982) observaram que de $30 \%$ do $\mathrm{N}$ proveniente do fertilizante no final do ciclo da cultura do milho $10,6 \%$ foi encontrado na palha (resto da cultura) e 19,4\% no grão.

Observaram também que o aproveitamento do $\mathrm{N}$ do fertilizante aumentou conforme os estádios da cultura até a época de maturação. Lara Cabezas et al. (2000), avaliando a eficiência de utilização do $N$ da uréia pelo milho, através do método isotópico, em SPD sobre palhada de milheto em Uberlândia-MG, encontraram valores inferiores a $30 \%$ do $\mathrm{N}$ aplicado, independentemente do modo de aplicação, superficial ou incorporado.

Verifica-se por tanto, que a resposta da cultura do milho ao $\mathrm{N}$, depende muito do sistema de manejo do solo, devido a sua dinâmica no sistema soloplanta ser dependente da temperatura, umidade e microrganismo, tipo de resíduos, histórico da área, dentre outros, justificando-se modelos diferenciados entre sistemas de cultivos. Assim, estudos de doses e épocas de aplicação do elemento, aliado ao uso de plantas de cobertura do solo, avaliando sua eficiência de utilização pelo milho, faz-se necessário no intuito de aumentar o seu aproveitamento e a produtividade do milho como mínimo risco ambiental. 
Nem sempre o $\mathrm{N}$ aplicado no solo será totalmente absorvido pelas plantas. Parte dele poderá ser imobilizada por microrganismos ou, ainda, ser perdida do sistema solo por diversos mecanismos (Byrnes, 2000). Como importante meio de perda do $\mathrm{N}$ aplicado, tem-se a forma gasosa, ou seja, $\mathrm{NH}_{3}$, $\mathrm{N}_{2}, \mathrm{~N}_{2} \mathrm{O}, \mathrm{NO}$. O N-NH perdido por volatilização será proveniente da mineralização da M.O. ou do fertilizante aplicado, sendo esse o fenômeno mais intenso mediante aumento no $\mathrm{pH}$ do solo (Melo, 1978).

Devido à ocorrência de perdas, a eficiência de aproveitamento de $\mathrm{N}$ pelas plantas é de $40 \%$ a $50 \%$. Tem-se pesquisado meios para reduzir perdas e aumentar a eficiência de uso do $\mathrm{N}$, como por exemplo, controle na época de aplicação, uso de revestimentos nos fertilizantes para controlar liberação de $\mathrm{N}$, além de melhorias nos métodos de aplicação. Para fontes nitrogenadas mais susceptíveis ás perdas, a prática de incorporação possibilita considerável redução na volatilização (Espironello, 1987; Lara Cabezas, 1987; Subirós \& Bertsch, 1998; Cantarella., 1999).

A eficiência é afetada pela forma de $\mathrm{N}$ aplicada na adubação; então, estudos com diferentes fontes de $\mathrm{N}$ passaram a ser realizados com objetivo de reduzir perdas e aumentar a eficiência. A uréia, que é uma das fontes nitrogenada mais utilizada para a agricultura brasileira, por apresentar elevada concentração de $\mathrm{N}$ e baixo custo por unidade de nitrogênio, apresenta grande susceptibilidade de perda de amônia $\left(\mathrm{NH}_{3}\right)$ por volatilização. Tal fenômeno tem sido considerado um dos principais motivos pelos quais a eficiência desse fertilizante em fornecer nitrogênio ás culturas está abaixo da esperada (Kiehl, 1989).

A dinâmica do $\mathrm{N}$ na natureza é de suma importância à vida das plantas porque envolve inúmeros fenômenos físicos, químicos e biológicos relacionados à disponibilidade do elemento aos vegetais. Ao contrário do que se observa com outros nutrientes como o $\mathrm{P}$ e o $\mathrm{K}$ a quantidade de $\mathrm{N}$ disponível no solo pode sofrer flutuações ás vezes severas em função de alterações os processos de adição e perda (KIEHL, 1987). Essas perdas, volatilização, desnitrificação e lixiviação são as grandes responsáveis pela baixa eficiência do uso de fertilizantes nitrogenados (IVANKO, 1972).

Segundo Volk (1959), a hidrólise da uréia ocorre em solos com vários teores de umidade. Quando mais rápida a hidrólise, maior o potencial de perda 
de $\mathrm{NH}_{3}$. A adição de água tem influência direta sobre a hidrólise e atua diretamente, promovendo aumento da difusão da uréia e, conseqüentemente, maior contato com a uréase no solo (Savant et al., 1987). A uréia aplicada é rapidamente hidrolisada em 2 ou 3 dias e a taxa de hidrólise depende da temperatura do solo, umidade, quantidade e forma pela qual a uréia é aplicada (Byrnes, 2000).

O carbonato de amônio resultante da hidrólise da uréia não é estável e desdobra-se em $\mathrm{NH}_{3}, \mathrm{CO}_{2}$ e água (Volk, 1959). Parte do $\mathrm{NH}_{3}$ formado reage com íons $\mathrm{H}^{+}$da solução do solo e com íons $\mathrm{H}^{+}$dissociáveis do complexo coloidal, resultando no cátion $\mathrm{NH}_{4}{ }^{+}$. Entretanto, a neutralização da acidez potencial determina a elevação do $\mathrm{pH}$, que pode atingir valores acima de 7 na região próxima aos grânulos do fertilizante aplicado. Na camada próxima à aplicação do fertilizante, constatou-se aumento do $\mathrm{pH}$ em água, de 6,9 para 8,7 (Rodrigues \& Kiehl, 1992). Diversos fatores afetam a volatilização de $\mathrm{N}-\mathrm{NH}_{3}$, como temperatura, umidade, trocas gasosas, taxa de evaporação da água, conteúdo de água no solo, pH, poder tampão, capacidade de troca catiônica, classe textural e atividade da urease. Valores elevados de $\mathrm{pH}$ conduzem à volatilização de $\mathrm{N}-\mathrm{NH}_{3}$ da uréia aplicada em superfície. Entretanto, fontes como sulfato de amônio, diamônio fosfato e nitrato de amônio, são menos susceptíveis à perdas por volatilização, pois não possuem características de aumentar o pH do local onde são aplicados (Freney et al., 1985; Hargrove, 1988; Byrnes, 2000; Penatti el al., 2001).

$\mathrm{O}$ nitrogênio do solo pode ser perdido pela volatilização da $\mathrm{NH}_{3}$. Os fatores que mais contribuem para este processo são as altas concentrações da própria amônia no solo, o pH elevado e as altas temperaturas do solo. A capacidade de troca de cátion (CTC) do solo também influi no processo, uma vez que a CTC interfere na distribuição do íon $\mathrm{NH}_{4}{ }^{+}$entre a solução no solo, e a fase sólida do solo (MELLO et al., 1983). Em um experimento de laboratório, Cantarella \& Tabatabai (1985) avaliaram a extensão da volatilização de $\mathrm{NH}_{3}$. Em solos ácidos e alcalinos de vários fertilizantes nitrogenados (uréia, sulfato de amônio, fosfato diamônio, formamida e oxamida), aplicados na superfície do solo descoberto, em sulco raso, misturado ao solo e sobre resíduo de matéria vegetal. 
Em sistema de plantio direto, na camada de 0-7 cm, observa-se uma predominância de nitrogênio na forma de nitrato e isto indica maior atividade dos microrganismos nitrificadores pós nesta camada do perfil, a umidade, a temperatura, o teor de carbono e o pH são favoráveis a nitrificação, o que poderia limitar possíveis perdas de $\mathrm{N}$ por volatilização. Por outro lado, a presença de resíduos vegetais sobre a superfície no SPD também reduz o contato da uréia com o solo (MENGEL, 1996), diminuindo a adsorção de $\mathrm{NH}_{4}^{+}$ aos colóides orgânicos e inorgânicos, e com isso facilitando a volatilização de amônia. Sangoi et al. (2003), avaliando os efeitos do modo de aplicação da uréia (sem N, uréia aplicada na superfície e uréia incorporada ao solo) e três métodos de manejo dos resíduos de aveia (sem palhada, palhada aplicada na superfície e palhada incorporada ao solo), em dois solos com diferentes teores de argila e matéria orgânica, verificaram que a aplicação superficial da uréia proporcionou maior volatilização de $\mathrm{N}-\mathrm{NH}_{3}$ do que sua incorporação, nos dois solos. A manutenção da palhada sobre a superfície do solo estimulou a perda de $\mathrm{N}-\mathrm{NH}_{3}$ no solo arenoso, independentemente da forma de aplicação da uréia ao solo.

A volatilização é um processo físico-químico resultante do equilíbrio entre $\mathrm{NH}_{3}$ na fase gasosa e em solução. A quantidade de $\mathrm{N}$ perdido por volatilização, após a aplicação de uréia sobre a superfície do solo, pode atingir valores extremos de até 80\% do N aplicado (MARTHA JÚNIOR, 1999). Essas perdas variam em função das condições climáticas, $\mathrm{pH}$, o tipo de solo e do manejo da adubação. A agricultura é responsável pela liberação de diversos gases que poluem o meio-ambiente como: amônia $\left(\mathrm{NH}_{3}\right)$ que contribui para acidificação e eutroficação dos solos e das águas; e o óxido nitroso $\left(\mathrm{N}_{2} \mathrm{O}\right)$ que contribui para o aquecimento global e destruição da camada de ozônio.

Primavesi et al. (2001) observaram que para chuvas em torno de $10 \mathrm{~mm}$, as perdas de $\mathrm{N}$-uréia ficaram abaixo de $17 \%$ nas áreas tratadas com $100 \mathrm{~kg} \mathrm{ha}$ ${ }^{1}$ de $\mathrm{N}$, chegando a ser superiores a $22 \%$, na mesma dose de $\mathrm{N}$-uréia sem a ocorrência de chuvas. Dos fatores climáticos, a temperatura e a precipitação pluviométrica geralmente são os de maior importância no processo de perdas, ainda que outros fatores, como a velocidade do vento, tenham influência (HARPER; SHARPE, 1995; MARTHA JÚNIOR, 2003). Altas temperaturas 
potencializam volatilizações de $\mathrm{NH}_{3}$, devido ao aumento na taxa de várias reações e na atividade da urease (TISDALE; NELSON; BEATON, 1985).

As perdas de $\mathrm{NH}_{3}$ por volatilização também são acentuadas quando as condições de umidade do solo ou de precipitação pluvial, após a aplicação da uréia, são insuficientes para proporcionar a movimentação do adubo para camadas mais profundas do solo. RODRIGUES; KIEHL, 1986, DENMEAD; FRENEY; JACKSON, 1990; MARTHA JÚNIOR, 2003.

As perdas por volatilização de $\mathrm{N}-\mathrm{NH}_{3}$ ocorrem mais intensamente na primeira semana após a aplicação da uréia (LARA CABEZAS; TRIVELIN, 1990, COSTA; VITTI; CANTARELLA, 2003). Isso ocorre devido à elevação do pH do solo causada pela hidrólises da uréia (OLIVEIRA, 2001), após esse período as perdas diminuem, provavelmente, em conseqüência da queda do $\mathrm{pH}$ do solo associada ao consumo de $\mathrm{OH}$ durante a volatilização e a nitrificação do amônio (WHITEHEAD, 1995).

No solo os fatores que mais influenciam a volatilização de $\mathrm{NH}_{3}$ são o pH, a capacidade de troca de cátions (CTC), o poder tampão e a matéria orgânica (TRIVELIN; LARA CABEZAS; BOARETTO, 1994; FENN; HOSSNER, 1985; MARTHA JÚNIOR, 2003). O pH altera o equilíbrio entre $\mathrm{NH}_{4}{ }^{+}$e $\mathrm{NH}_{3}$ na solução do solo, de forma que em solos com baixos valores de $\mathrm{pH}$, a forma de $\mathrm{N}$ amoniacal predominante é $\mathrm{NH}_{4}^{+}$e o potencial de volatilização é baixo, já em solos com altos valores de $\mathrm{pH}$ a forma predominante é o $\mathrm{NH}_{3}$ e o potencial de volatilização é alto (HARRISON; WEBB, 2001).

A baixa CTC possibilita menor retenção o íon amônio, diminuindo a permanência do íon na forma trocável e aumentando as possibilidades de perdas (OLIVEIRA, 2001). A presença de resíduos orgânicos e conseqüente atividade da enzima urease também estimulam as perdas por volatilização de $\mathrm{N}-\mathrm{NH}_{3}$ (OLIVEIRA, 2001). Outro fator que influencia a volatilização é o manejo de adubação através das fontes de nitrogênio utilizadas, doses e a forma de aplicação. 


\subsubsection{Desnitrificação}

De acordo com Moreira e Siqueira (2002), todos os processos redutivos o mais conhecido é a desnitrificação, que consiste na redução bioquímica de formas oxidadas à formas gasosas $\left(\mathrm{N}_{2}\right.$ e $\left.\mathrm{N}_{2} \mathrm{O}\right)$, na seguinte seqüência: ${ }_{2} \mathrm{NO}_{3} \longrightarrow$ ${ }_{2} \mathrm{NO}_{2} \longrightarrow{ }_{2} \mathrm{NO} \longrightarrow \mathrm{N}_{2} \mathrm{O} \longrightarrow \mathrm{N}_{2}$. O processo é realizado por varias bactérias anaeróbicas facultativas, como a do gênero Azospirillum, Bacillus, Pseudomonas, Rhizobium, etc. Segundo os mesmos autores a desnitrificação é um processo de grande importância geoquímica e ambiental, porém muito complexa. Nas bactérias desnitrificadoras, as formas oxidadas de $\mathrm{N}$ atuam como aceptores terminais de elétrons oriundos da oxidação de substratos, conforme Paul e Clark (1989). Os elétrons de substratos orgânicos e inorgânicos fluem numa cadeia, do $\mathrm{NAD}^{+}$ao citrocromo-B e sistemas redutases para as formas de $\mathrm{N}$ com diferentes estágios de oxidação, causando a redução destes até o produto final $\mathrm{N}_{2}$.

Ainda segundo Moreira e Siqueira (2002) a desnitrificação ocorre quando houver ausência de $\mathrm{O}_{2}$, presença de $\mathrm{NO}_{3}^{-}$e compostos reduzidos (carbono orgânico para os organotróficos), ou $\mathrm{S}, \mathrm{HS}$ ou o $\mathrm{NH}_{4}{ }^{+}$para litotróficos e obrigatoriamente os microrganismos desnitrificadores têm que estar presentes. Perda de nitrogênio por desnitrificação têm sido tradicionalmente avaliada em estudos com ${ }^{15} \mathrm{~N}$ no sistema solo planta, obtida indiretamente como a quantidade do $\mathrm{N}$-fertilizante não recuperado pela planta e no solo.

Embora seja um processo freqüente em solos com baixo suprimento de $\mathrm{O}_{2}$, poderá ocorrer também em solos bem drenados, onde matéria orgânica tenha sido adicionado. O suprimento de carbono promove o crescimento microbiano e o consumo de $\mathrm{O}_{2}$. Microsítios anaeróbicos são criados, onde um grupo de bactérias anaeróbicas facultativas utilizam os óxidos iônicos de $\mathrm{N}$ como receptores. Então, predominância de microrganismos anaeróbicos na superfície de solos sob plantio direto tem sido encontrada e tem sido associada a condições de maior umidade (BARTZ, 2006). Sainz Rozas, Echeverria e Picone (2001), com objetivo de avaliar o efeito de doses de N (0, 70 e $210 \mathrm{~kg}$ $\mathrm{ha}^{-1}$ ) e diferentes épocas de aplicação (plantio e no estádio de 6 folhas), sobre perdas por desnitrificação em milho irrigado, em plantio direto, concluíram que a perda por desnitrificação quando se aplicou $\mathrm{N}$ no plantio foi de 7,6 e 9,8 kg 
ha $^{-1}$ de $\mathrm{N}_{2} \mathrm{O}$ (5,5 e 2,6\% do $\mathrm{N}$ aplicado para 70 e $210 \mathrm{~kg} \mathrm{ha}^{-1}$, respectivamente). Quando o $\mathrm{N}$ foi aplicado na cultura no estádio de 6 folhas, as perdas por desnitrificação foram de 2,0 e 2,1 $\mathrm{kg} \mathrm{ha}^{-1}$ de $\mathrm{N}_{2} \mathrm{O}(1,0$ e $0,4 \%$ do $\mathrm{N}$ aplicado para 70 e $210 \mathrm{~kg} \mathrm{ha}^{-1}$, respectivamente).

Já Gollany et al. (2007) em estudos com fertilização de N (20 e 200 kg $\mathrm{ha}^{-1}$ de $\mathrm{N}$ ) em milho e dois manejos (resíduo colhido e retorno residual) verificaram que as perdas por desnitrificação fora de 43, 51 e $56 \mathrm{~kg} \mathrm{ha}^{-1}$ ano $^{-1}$ para a baixa taxa de $\mathrm{N}$ aplicado e 44,70 e $85 \mathrm{~kg} \mathrm{ha}^{-1} \mathrm{ano}^{-1}$ para a alta taxa de $\mathrm{N}$ aplicada quando o resíduo foi retornado ao solo em 0, 66\% e 100\%, respectivamente.

Estudos recentes indicam que o $\mathrm{NO}$ e $\circ \mathrm{N}_{2} \mathrm{O}$ podem também ser produzidos a partir da oxidação do $\mathrm{NH}_{4}{ }^{+}$, indicando que nem toda oxidação de $\mathrm{NH}_{4}{ }^{+}$é nitrificação. O gás $\mathrm{N}_{2} \mathrm{O}$ pode surgir pela dismutação química do nitroxil $(\mathrm{NOH})$ e através da ação da nitrito redutase:

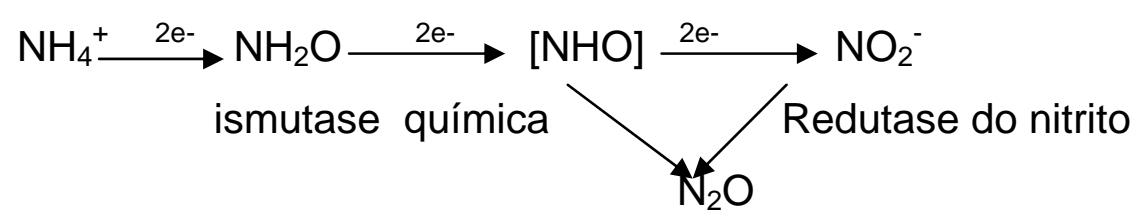

\subsubsection{Lixiviação}

Segundo Kiehl (1987), lixiviação é a translocação de sais solúveis que se dá através de fluxo descendente de água no perfil do solo. No caso do nitrogênio, a lixiviação é de suma importância porque pode diminuir sensivelmente a quantidade de amônia e nitrato na camada arável e, conseqüentemente reduzir a disponibilidade do nutriente; quando excessiva, a lixiviação constitui um perigo potencial de contaminação de água subterrâneas por nitrato (STARK; JARREL; LETEY, 1983). Durante as últimas décadas, a contaminação dos mananciais de água superficiais e profundos com nutrientes, particularmente $\mathrm{N}$ e $\mathrm{P}$, tornou-se um assunto significativo para o público, incluso os produtores. As elevadas concentrações de nitrato na água para consumo humano são preocupantes, porque causam metahemoglobinemia, comumente conhecida como bebê azul. Este é um problema que ocorre 
somente em crianças com menos de seis meses e mulheres grávidas. Além disso a contaminação de água por nitratos e $\mathrm{P}$ tem sido relacionada com uma outra anormalidade denominada hipoxia (baixo teor de oxigênio) nas águas do Golfo do México a qual inibe a produção de camarões e de outras espécies aquáticas nesta zona (HOEFT, 2003). Para os EUA, a concentração máxima de nitrato e nitrito para uma água ser considerada potável e não causar danos à saúde humana é de $10 \mathrm{mg} \mathrm{L}^{-1}$ e $1 \mathrm{mg} \mathrm{L}^{-1}$, respectivamente, sendo os mesmos valores adotados pela Legislação Brasileira, mas para a União Européia o valor de nitrato permitindo chegar a $50 \mathrm{mg} \mathrm{L}^{-1}$ (TUNDISI, 2003).

A lixiviação de $\mathrm{N}$ ocorre em ordem decrescente para $\mathrm{NO}_{3}{ }^{-}>\mathrm{NH}_{4}{ }^{+}>\mathrm{N}$ orgânico. A maior lixiviação na forma de nitrato ocorre por causa de sua carga negativa ser repelida pelos colóides de solo onde predomina a mesma carga (GONÇALVES; CERETTA; BASSO, 2000). A quantidade de $\mathrm{N}$ que se perde por lixiviação varia muito em função da dose de $\mathrm{N}$ no método de aplicação do fertilizante, da velocidade de mineralização e imobilização por plantas e microrganismos, da quantidade de chuva e das propriedades do solo que influenciam sua capacidade de reter água quais sejam, a textura, a estrutura e a propriedade (KIEHL, 1987). Reichardt et al. (1979), estudando a dinâmica do nitrogênio $\left(80 \mathrm{~kg} \mathrm{ha}^{-1}\right.$ ) como sulfato de amônio marcado com ${ }^{15} \mathrm{~N}$ aplicado a uma cultura de milho, encontraram que, durante um período de 97 dias, foram lixiviados aproximadamente $9,2 \mathrm{~kg} \mathrm{ha}^{-1}$ de $\mathrm{N}$, sendo $0,4 \mathrm{~kg} \mathrm{ha}^{-1}$ de $\mathrm{N}$ do adubo, a uma profundidade limite de $120 \mathrm{~cm}$. Reichardt; Libardi \& Urquiaga (1982) revisaram trabalhos conduzidos no Brasil sobre o balanço do nitrogênio no sistema solo-planta, utilizando a técnica do isótopo $\left({ }^{15} \mathrm{~N}\right)$ e discutiram os diferentes componentes do balanço, com ênfase para as perdas de $\mathrm{N}$ do solo e fertilizante por lixiviação.

Sexton et al. (1996) observaram que $\mathrm{O} \mathrm{NO}_{3}^{-}$lixiviado aumentou rapidamente quando as doses de $\mathrm{N}$ excederam a $100 \mathrm{~kg} \mathrm{ha}^{-1}$ para crescimento de milho sob um solo arenoso e quando doses de $\mathrm{N}$ aumentaram acima de 250 $\mathrm{kg} \mathrm{ha}^{-1}$ (correspondendo ao máximo rendimento), $\mathrm{o} \mathrm{NO}_{3}^{-}$lixiviado aumentou exponencialmente. Gava (2003) revisando trabalhos de perdas de N por lixiviação, entre os anos de 1978 a 1999, observaram que em 78\% dos experimentos realizados em diferentes solos e cultivos, fertilizados em média 
com uma dose de $92 \mathrm{~kg} \mathrm{ha}^{-1}$ de $\mathrm{N}$, as perdas do $\mathrm{N}$ total por meio de lixiviação foram pequenas, em média de $1,26 \mathrm{~kg} \mathrm{ha}^{-1}$ de $\mathrm{N}$.

Verificou também, que em $67 \%$ dos experimentos, as perdas de $\mathrm{N}$ fertilizante foram pequenas e inferiores a $0,30 \mathrm{~kg} \mathrm{ha}^{-1}$ de $\mathrm{N}$. Entretanto, deve-se destacar que nos trabalhos desenvolvidos por Silva (1982); Camargo (1989) as perdas de $\mathrm{N}$ Fertilizante por lixiviação foram altas, chegando a ser respectivamente de 11 (150 dias em milho) e 34\% (102 dias em cana de açúcar). Esses autores ressaltaram que as perdas de $\mathrm{N}$ por lixiviação foram elevadas devido às precipitações intensas ocorridas logo após a aplicação de fertilizante e também pelo reduzido volume de solo explorado pelo sistema radicular das culturas. Sogbedji; Van Es \& Yang (2000) verificaram que as perdas de nitrato por lixiviação foram similares, no $1^{\circ}$ ano de cultivo de milho para as doses de $\mathrm{N}$ aplicada (22, 100 e $134 \mathrm{~kg} \mathrm{ha}^{-1}$ de $\mathrm{N}$ ), nos dois tipos de solos testados (arenoso e argiloso) e para os outros dois cultivos de milho, a dose de $134 \mathrm{~kg} \mathrm{ha}^{-1}$ de $\mathrm{N}$ apresentou maior perda de nitrato por lixiviação. 


\subsection{Mineralização e métodos para determinação de perdas de $\mathrm{N}-\mathrm{NH}_{3}$}

A mineralização é a conversão do $\mathrm{N}$ orgânico em $\mathrm{N}$ mineral $\left(\mathrm{NH}_{4}{ }^{+}\right.$e $\mathrm{NO}_{3}{ }^{-}$ ), realizadas por microrganismos quimiorganotróficos. Esse processo nos agroecosistemas é governado pelas condições edafoclimáticas, onde a temperatura, a umidade a relação $\mathrm{C} / \mathrm{N}$ dos resíduos vegetais, a textura do solo, o $\mathrm{pH}$ e o tipo de argila são os principais fatores controladores do mesmo. A imobilização caracteriza-se no fenômeno oposto a mineralização, representado a passagem do $\mathrm{N}$ na forma mineral, oriundo dos fertilizantes minerais ou orgânicos (reimobilização) para a forma orgânica. Entretanto, esse processo além de ser promovido por microrganismos quimiorganotróficos, é realizado também pelas plantas através da assimilação e incorporação em seus tecidos. Apesar da redução drástica do teor de $\mathrm{N}$ mineral no solo na presença de resíduos de alta relação $\mathrm{C} / \mathrm{N}$ (>30/1), a imobilização não representa uma perda irreversível de $\mathrm{N}$ para a cultura subseqüente, em virtude da população microbiana não cresce indefinidamente, começando a ocorrer progressiva liberação de $\mathrm{N}$ a partir do ponto em que o carbono facilmente oxidável começa a desaparecer (Victória et al., 1992; Lopes et al., 2004). A maioria dos pesquisadores consideram a relação $\mathrm{C} / \mathrm{N}$ de $25 / 1$ como o ponto de equilíbrio, onde inferior a esta começa a ocorrer liberação de $\mathrm{N}$ para o solo. Ressalta-se entretanto, que esses processos ocorre no solo simultaneamente podendo ocorrer reimobilização e remineralização do mesmo "pool" de N.

A nitrificação constitui-se na oxidação do $\mathrm{N}$ amoniacal (forma mais reduzida de $\mathrm{N}$ no solo) a nitrito e depois a nitrato (forma mais oxidada de $\mathrm{N}$ no solo). Esse processo é mediado, predominantemente, por microrganismos quimiorganotróficos especializados, onde as bactérias do gênero nitrossomonas transformam $\mathrm{NH}_{4}{ }^{+}$a $\mathrm{NO}_{2}^{-}$e as do gênero nitrobacter transformam $\mathrm{NO}_{2}^{-}$a $\mathrm{NO}_{3}{ }^{-}$. O processo acidificante para o meio em virtude da liberação de $\mathrm{H}^{+}$durante as reações (Victória et al., 1992).

De acordo com Moreira \& Siqueira (2002), as estimativa de quantidade de $\mathrm{N}$ mineralizado é elevada, sendo da ordem de 2,5 vezes maior que o total de $\mathrm{N}$ absorvido pelas culturas. Destes valores estima-se que as plantas absorvam apenas em torno de $40 \%$ do $\mathrm{N}$-mineralizado, indicando constantes 
perdas de $\mathrm{N}$ para o sub-solo ou para a atmosfera. Verificou-se também que a desnitrificação e a lixiviação são os principais processos de perdas de $\mathrm{N}$ do solo, os quais juntos contribuem com $72 \%$ da perda total.

Lara Cabezas \& Trivelin (1990) realizaram levantamento de literatura e encontraram que, entre os métodos apresentados para estimar perdas por volatilização de amônia do solo, provenientes da aplicação de fertilizantes nitrogenados, os micrometeorológicos (métodos diretos) e os métodos por balanço isotópico de ${ }^{15} \mathrm{~N}$ (método direto) são os únicos que permitem quantificar o processo sem influência na atmosfera próxima à superfície do solo, bem como nas propriedades químicas e biológicas deste. Métodos diretos precisam de aparelhos específicos, que podem dificultar sua pratica (Lara Cabezas \& Trivelin, 1990). Já os métodos indiretos, que consistem na determinação da amônia volatilizada pela diferença entre o $\mathrm{N}$-fertilizante aplicado e o residual no solo, somado ao retirado pelas plantas e descontandose o nativo, podem ser efetuados usando-se fertilizante isotopicamente marcado $\left({ }^{15} \mathrm{~N}\right)$ (Nönmik, 1973; Rashid, 1977; Moraghan et al., 1984; San, 1986).

Determinações estabelecidas pelo método ${ }^{15} \mathrm{~N}$ apresentam alto custo e têm sido empregadas em estudos de balanço nitrogenado no sistema soloplanta-atmosfera, onde pode-se quantificar perdas, bem como a calibração de métodos diretos que utilizam-se de câmaras coletoras (Lara Cabezas \& Trivelin, 1990). Medidas pelo critério direto podem ser realizadas no laboratório, casa de vegetação ou no campo por meio dos sistemas fechado-estático, fechado-dinâmico e semi-aberto estático. O sistema fechado-estático isola 0 solo do ar atmosférico. No sistema fechado dinâmico faz-se circulação forçada de ar (Rodrigues \& Kiehl, 1986; Reynolds \& Wolf, 1987). Tais sistemas fechados podem impossibilitar a obtenção de observações da volatilização que ocorreria em condições naturais, pois modificam o ambiente na superfície do solo (Lara Cabezas \& Trivelin, 1990).

Em contra-partida, os coletores descritos por Nönmik (1973), com sistema semi-aberto estático, são utilizados para estudos de campo. Possuem abertura permanente que possibilita o equilíbrio da atmosfera interna do aparelho com o ar exterior, minimizando interferências na determinação da amônia volatilizada. O coletor semi-aberto estático, no entanto, também 
apresenta limitações. Essas limitações foram avaliadas por Lara Cabezas e Trivelin (1990), na quantificação do $\mathrm{N}^{-\mathrm{NH}_{3}}$ volatilizado de adubos nitrogenados aplicados ao solo. Os autores observaram que a presença do sistema coletor semi-aberto estático influiu significativamente, reduzindo a porcentagem e quantidade de amônia volatilizada do fertilizante.

Apesar de possibilitarem o intercambio relativamente livre do ar entre a superfície do solo e a atmosfera permitindo a difusão da amônia, eles provocam alterações na temperatura, umidade relativa, taxa de evaporação da água do solo e pressão de amônia no ambiente da câmera, reduzindo a percentagem e a quantidade de amônia volatilizada do fertilizante (LARA CABEZAS; TRIVELIN, 1990).

Também o método micrometeorológico integra o fluxo de entrada e saída de amônia em uma grande área, a vantagem desse método em relação aos métodos com câmeras é que ele não interfere nos processos de volatilização, uma vez que não altera as condições ambientais próximas a superfície do solo (TRIVELIN, 2001). Porém, requere a utilização de aparelhos sofisticados e caros, como microanemômetros e detectores de gases (DENMEAD, 1983).

Os métodos com câmeras são relativamente simples e próprios para experimentos com parcelas pequenas e com vários tratamentos numa mesma área, uma das vantagens desse sistema é a formação de microclima modificação das condições ambientais no seu interior, como: intensidade e comprimento de onda da luz; temperatura; ventilação; umidade relativa e a formação do orvalho que certamente influenciam a volatilização de $\mathrm{NH}_{3}$ quando comparado com condições naturais (TRIVELIN, 2001; LARA CABEZAS; TRIVELIN, 1990).

Pesquisadores trabalhando no desenvolvimento de coletores de amônia para medidas de volatilização em condições de campo no Brasil (LARA CABEZAS, 1987; LARA CABEZAS; TRIVELIN,1990; TRIVELIN et al., 1997; LARA CABEZAS et al., 1999), calibraram um coletor semi-aberto estático, usando como referência o método como por balanço de ${ }^{15} \mathrm{~N}$ sem influência da câmera. Isso possibilitou quantificar as perdas de amônia por volatilização sem o uso de fertilizantes ${ }^{15} \mathrm{~N}$ e representando a condição de ausência do coletor (TRIVELIN, 2001). 
O outro método utilizado para quantificar as perdas por volatilização é o balanço de ${ }^{15} \mathrm{~N}$, no qual as perdas de amônia são estimadas indiretamente pela diferença entre a massa de ${ }^{15} \mathrm{~N}$, no qual as perdas de amônia são estimadas indiretamente pela diferença entre a massa de ${ }^{15} \mathrm{~N}$ adicionada pelo fertilizante e a massa recuperada de ${ }^{15} \mathrm{~N}$ adicionada pelo fertilizante e a massa recuperada de ${ }^{15} \mathrm{~N}$ após um determinado tempo de medida (TRIVELIN, 2001). Estes métodos podem quantificar as perdas por volatilização, desde que as perdas por desnitrificação e lixiviação sejam evitadas ou quantificadas. Também é possível calibrar métodos diretos que utilizam câmeras de retenção de amônia. A principal restrição que tem sido feita ao uso do ${ }^{15} \mathrm{~N}$ relaciona-se aos custos de fontes marcadas com o isótopo e das análises isotópicas (LARA CABEZAS; TRIVELIN, 1990).

\subsection{Qualidades nutricionais do milho}

Os grãos de milho possuem inúmeras utilizações, tanto na forma natural como na industrializada. Em muitos países em desenvolvimento, representam parte importante na dieta humana, de forma que não podem ser considerados apenas como fonte de energia, pois também contribuem com uma porção importante de proteínas.

Outra utilização de grande importância dos grãos de milho ocorre na alimentação animal, especialmente de aves e suínos, juntos consomem quase 90\% das rações produzidas no Brasil (Anfar/Sindirações, 1999). Dessa forma, grande parte da produção de milho brasileiro destina-se à alimentação de aves e suínos, os quais devem ser alimentados com ingredientes que apresentem qualidade para atender os mercados internos e externos.

De acordo com Mitellmann (2001), as aves e suínos apresentam exigências quanto ao teor de proteína e de aminoácido, essenciais na dieta. Sua suplementação pode representar custos adicionais, uma vez que a alimentação representa a parte dos custos de produção. Apesar do potencial que o milho apresenta como fonte protéica, contendo cerca de 10\% de proteína na matéria seca do grão, este cereal é considerado um alimento energético 
para seres humanos e animais monogástricos, graças à sua deficiência em aminoácidos essenciais, como lisina e triptofano.

Embora o milho seja, predominantemente, uma fonte de energia, sua proteína é importante fonte de aminoácidos, principalmente pelo fato desse ingrediente representar, em média, 55\% a 80\% das rações de aves e suínos. Sendo assim, o desenvolvimento de variedades de milho, com maiores teores de proteína e com um balanço adequado de aminoácidos, permitiria a elevação do seu valor nutritivo, sem prejuízo para o rendimento de grãos. 


\section{MATERIAL E MÉTODOS}

\subsection{Localização e caracterização da área experimental}

O experimento foi conduzido, em condições de campo, no Departamento de Zootecnia da Faculdade de Zootecnia e Engenharia de Alimentos da Universidade de São Paulo-FZEA/USP, em área pertencente à Prefeitura do Campus Administrativo da USP localizada no Município de Pirassununga, SP $\left(21^{\circ} 59^{\prime} \mathrm{S}\right.$ e $47^{\circ} 26^{\prime} \mathrm{W}, 634 \mathrm{~m}$ de altitude), sendo a classificação Internacional de Koppen, como do tipo Cwa, denominado "tropical de altitude" (Oliveira \& Prado 1984). É um clima mesotérmico de inverno seco, em que a temperatura média do mês mais frio é inferior a $18{ }^{\circ} \mathrm{C}$ e a do mês mais quente ultrapassa 22 ${ }^{\circ} \mathrm{C}$. As médias anuais de temperatura, precipitação e umidade relativa do ar são de $21,1{ }^{\circ} \mathrm{C}, 1.257 \mathrm{~mm}$ e $74 \%$, respectivamente. A estação seca ocorre entre os meses de abril e setembro, sendo julho o mês mais seco. O mês mais chuvoso oscila entre janeiro e fevereiro e o total das chuvas do mês mais seco não ultrapassa $30 \mathrm{~mm}$ (Serviço Nacional de Pesquisas Agronômicas, 1960). O solo do local é do tipo Latossolo Vermelho Amarelo (EMBRAPA, 1999), distrófico (Typic Hapludox) férrico.

Antes da implantação do experimento foram coletadas amostras de solo nas camadas de 0-20 e 20-40 cm para a determinação de características químicas e físicas do perfil, as quais estão apresentadas nas Tabela 1 e 2. A análise granulométrica (Tabela 3), foi realizada de acordo com o método descrito por Gee e Bauder (1986). O experimento envolveu o cultivo de milho que foi conduzido no período de 16/12/2006 a 10/05/2007, onde se realizou a adubação de cobertura nas parcelas experimentais nos respectivos tratamentos.

As análises químicas e físicas do solo, químicas de folhas, e todas as determinações envolvidas nas perdas de $\mathrm{N}^{-\mathrm{NH}_{3}}$ foram feitas no laboratório das Ciências Agrárias do Departamento de Zootecnia da FZEA/USP. 
Tabela 1. Atributos químicos do solo antes da instalação do experimento nas camadas de 0-20 e $20-40 \mathrm{~cm}$, para macronutrientes.

\begin{tabular}{llllllllllll}
\hline Profund. & pH & MO & P & S & K & Ca & Mg & H+Al & CTC SB & V & m
\end{tabular}

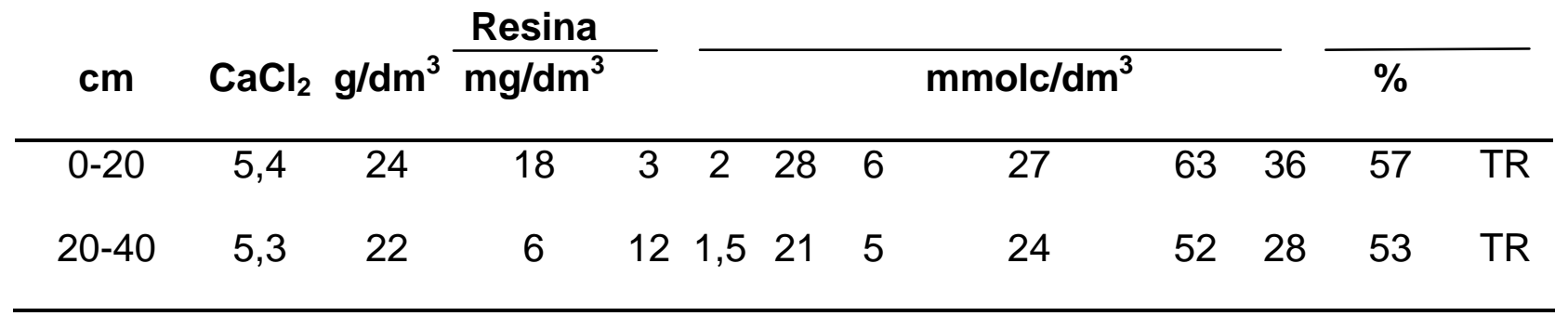

Prof. - Profundidade em $\mathrm{cm}$.

pH- $\mathrm{CaCl}_{2}$ 0,01 mol L-1 (Raij et al., 1987).

M.O. - Matéria orgânica, método colorimétrico (Raij et al., 1987).

P - Extração por resina trocadora de íons e determinação por colorimetria (Raij et al., 1987).

$\mathrm{S}=\mathrm{Ca}(\mathrm{H} 2 \mathrm{PO} 4) 2 . \mathrm{H} 2 \mathrm{O}-$ Método de Turbidimetria (MALAVOLTA et al., 1989).

K - Extração por resina trocadora de íons e determinação por fotometria de chama (Raij et al., 1987).

Ca e Mg - Extração por resina trocadora de íons e determinação por espectrometria de absorção atômica (Raij et al., 1987).

H+Al - Determinação potenciométrica em solução tampão SMP (Raij et al., 1987).

$\mathrm{Al}-\mathrm{KCl} 1 \mathrm{~N}$ : Determinação por titulação 
Tabela 2. Atributos químicos do solo, antes da instalação do experimento, nas camadas de 0-20 e 20-40 cm, para micronutrientes.

\begin{tabular}{cccccc}
\hline $\begin{array}{c}\text { Prof. } \\
\mathrm{cm}\end{array}$ & $\mathrm{B}$ & $\mathrm{Cu}$ & $\mathrm{Fe}$ & $\mathrm{Mn}$ & $\mathrm{Zn}$ \\
\cline { 2 - 6 } $0-20$ & 0,31 & 4,8 & 15 & 26,5 & 2,4 \\
& & & & & \\
$20-40$ & 0,27 & 3,7 & 14 & 25,8 & 1,9 \\
\hline
\end{tabular}

Prof. - Profundidade em $\mathrm{cm}$.

$\mathrm{B}=\mathrm{BaCl}_{2} \cdot 2 \mathrm{H}_{2} \mathrm{O} \mathrm{H} \mathrm{H}_{2} \mathrm{O}$ quente $10 \mathrm{ml}$ TFSA (Raij et al., 1987).

Cu, Fe, Mn, Zn - DTPA-TEA pH 7,3 (Raij et al., 1987).

Depois da amostragem do solo, fez-se a uniformização das plantas invasoras (Carrapicho, Capitão do mato e Brachiaria) entre outras com uma roçadora e posteriormente aplicou-se o herbicida glifosate na dose de 5 litros/ha com trator para dessecar o capim e permitir o plantio direto.

Tabela 3. Atributos físicos do solo da área experimental/Análise granulométrica

\begin{tabular}{ccccc}
\hline \multirow{2}{*}{ Prof. (cm) } & Areia total & Silte & Argila total & Classe de textura \\
\cline { 2 - 5 } & & \multicolumn{3}{c}{$\%$} \\
\hline $0-20$ & 36,3 & 6,33 & 57,45 & Argilosa \\
\hline $20-40$ & 35,3 & 6,64 & 58,23 & Argilosa
\end{tabular}

Método do densimetro (Bouyoucos, 1927)

\subsubsection{Instalação do experimento}

A instalação do experimento foi realizado no sistema plantio direto, com a área ocupada anteriormente pela cultura de milho. Essa área permaneceu em pousio durante o período de entre safra, sendo efetuada o corte das plantas daninhas com roçadora e depois a dessecação com herbicida glifosate na dose de 5 litros/ha do produto comercial (Figuras 1, 2, 3 e 4). 


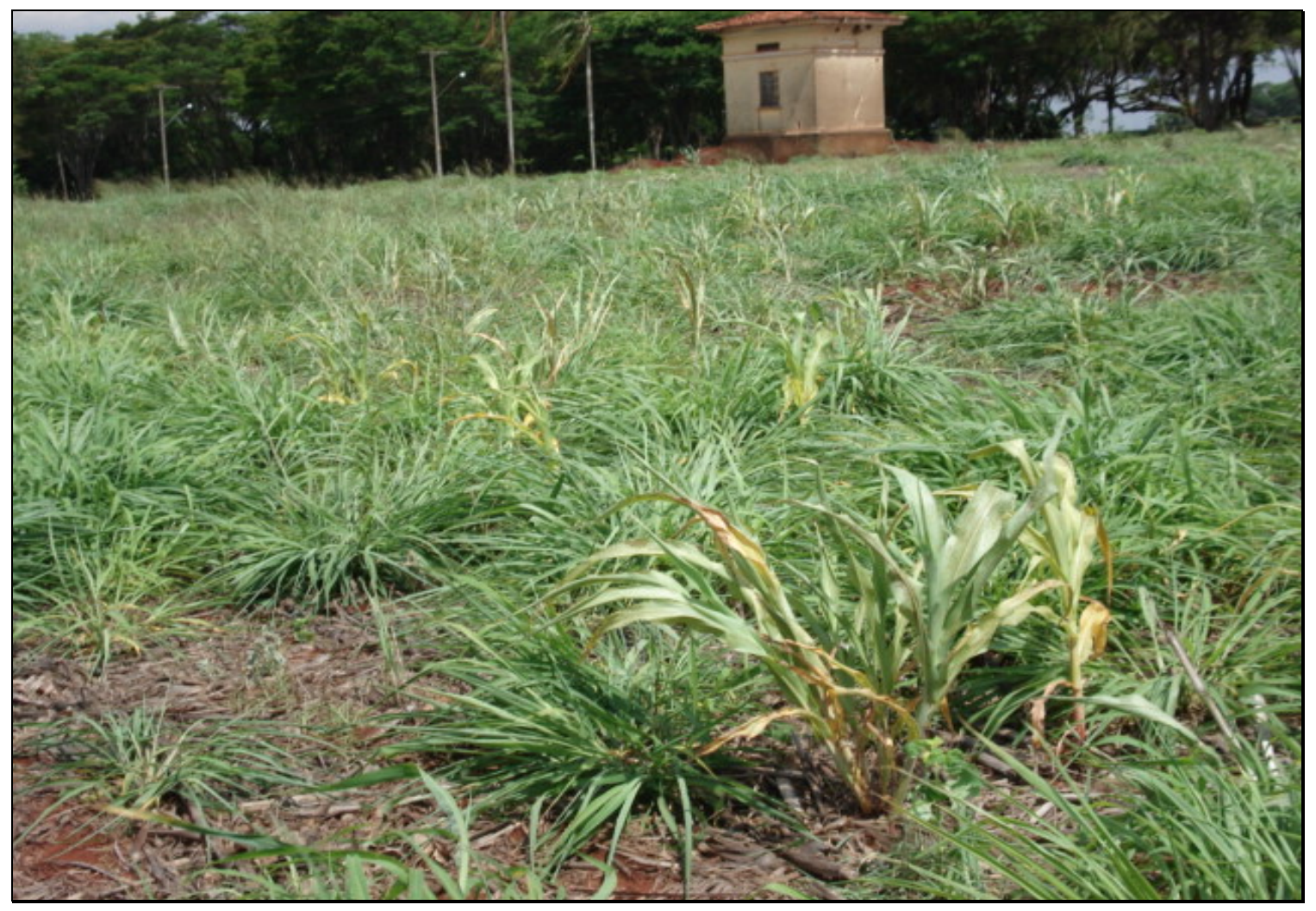

Figura 1. Área antes de a instalação do experimento.

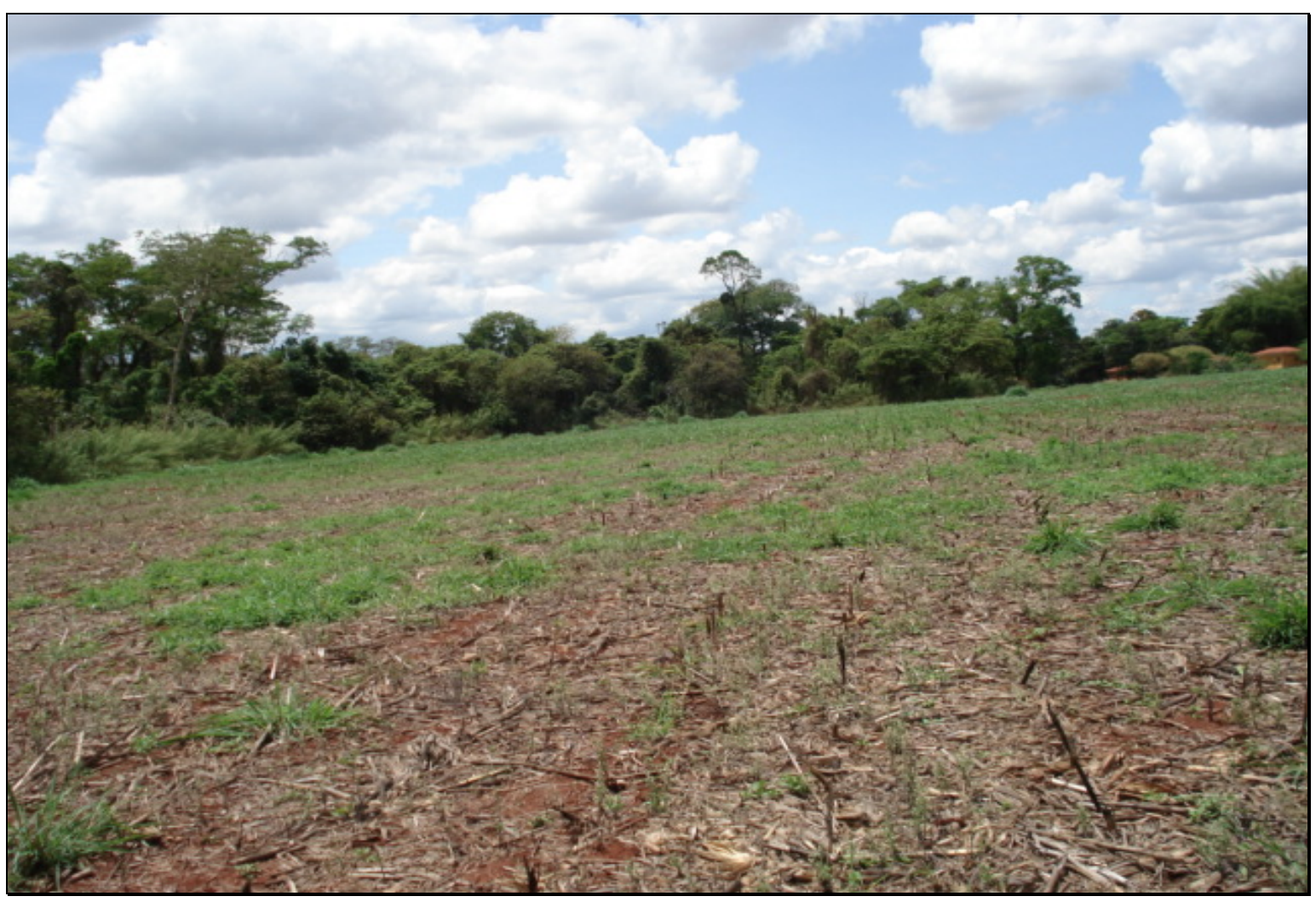

Figura 2. Área antes da instalação do experimento. 


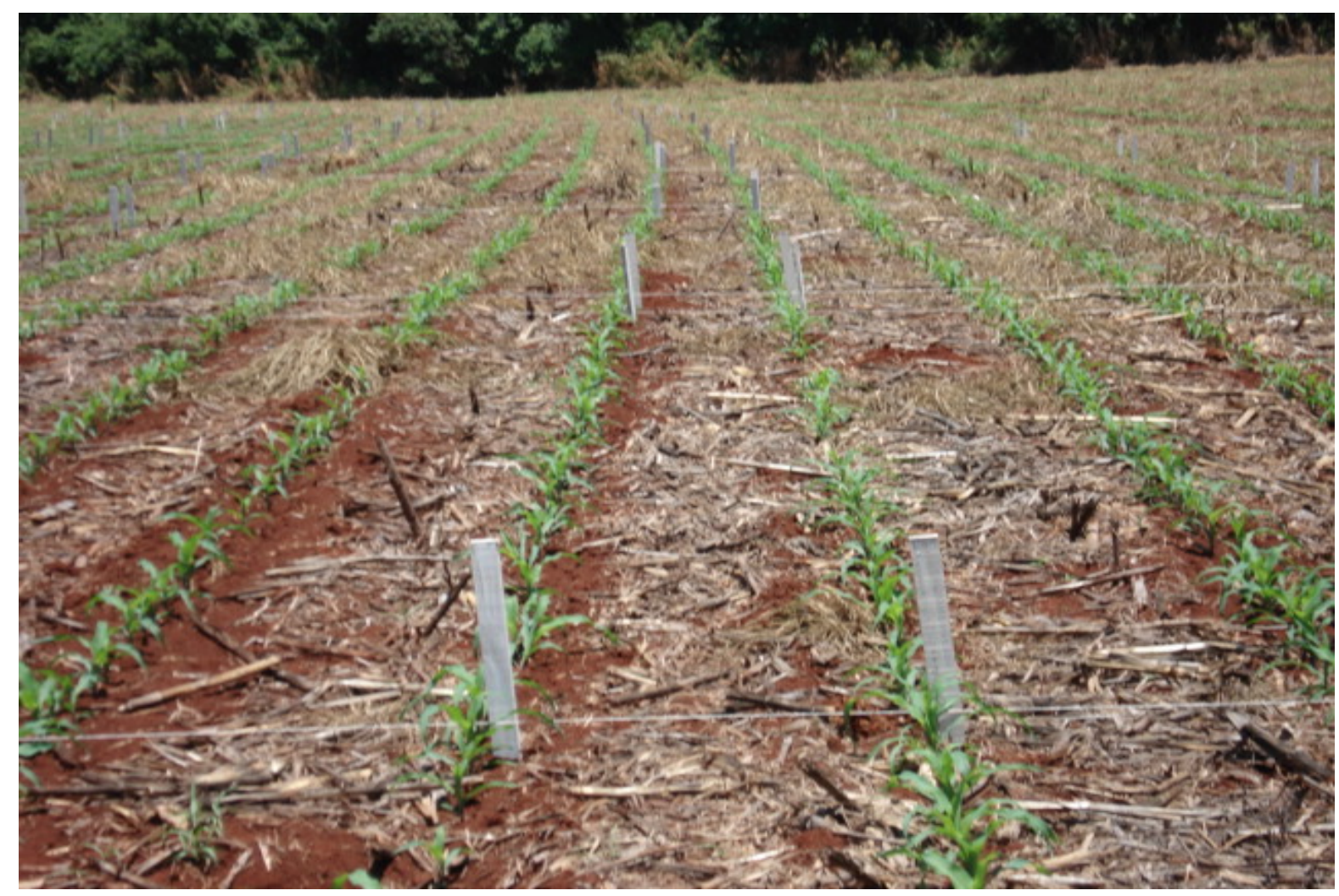

Figura 3. Marcação da área do experimento.

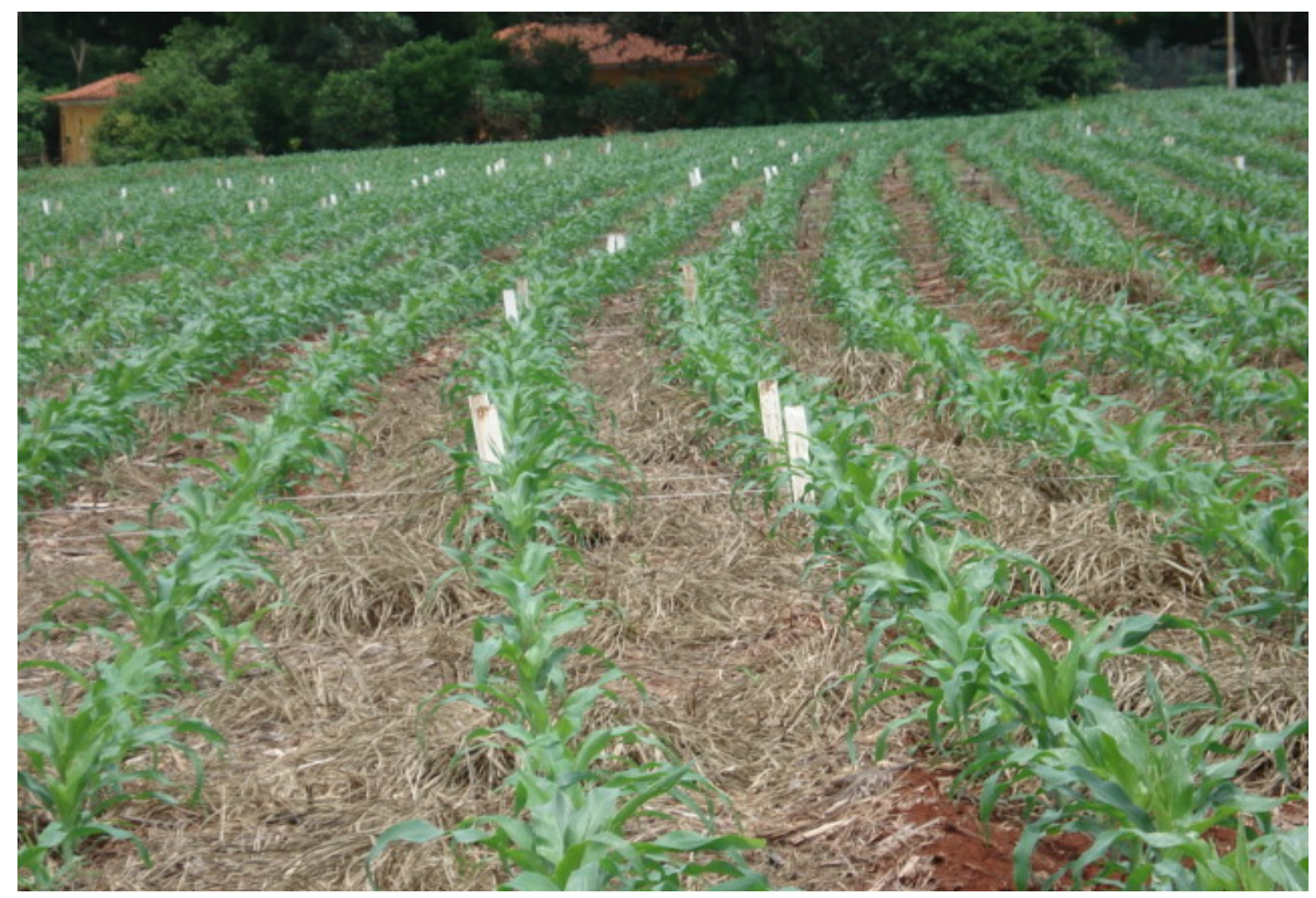

Figura 4. Marcação da área do experimento. 


\subsubsection{Dados climatológicos}

O experimento foi monitorado quanto a pluviosidade e temperaturas máximas e mínimas diária, e a precipitação por meio de uma estação meteorológica informatizada instalado no campus da USP/FZEA, como mostra a (Figura 5). Os dados pluviométricos e de temperaturas máximas e mínimas (média mensal) ocorridos durante a condução do experimento podem ser visualizados nas Figuras 6, 7, e 8. DIDONET et al. (2002) afirmam que, em geral as temperaturas do ar para o crescimento de milho estão entre 30 e $35^{\circ} \mathrm{C}$ e as temperaturas mínimas, entre 6 e $8^{\circ} \mathrm{C}$. BASSOI e REICHARDT (1995) apontam que as temperaturas de 10,30 e $40{ }^{\circ} \mathrm{C}$ são consideradas a mínima, ótima e máxima, respectivamente para o crescimento de plantas de milho. Depois da instalação do experimento no dia 16/12/2006 a 22/12/2006 o total de precipitação foi de $47,4 \mathrm{~mm}$.

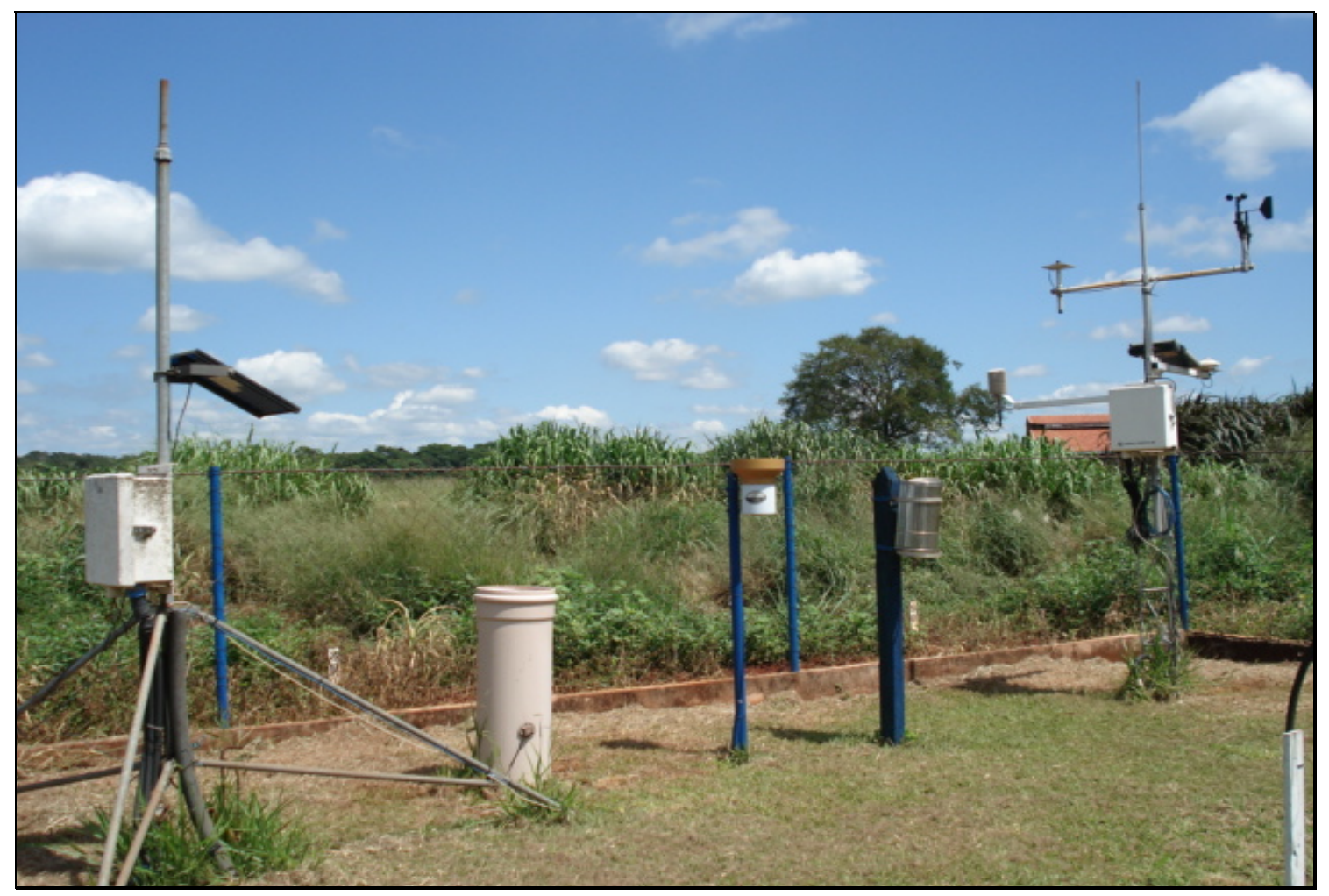

Figura 5. Estação de meteorologia da FZEA/USP. 


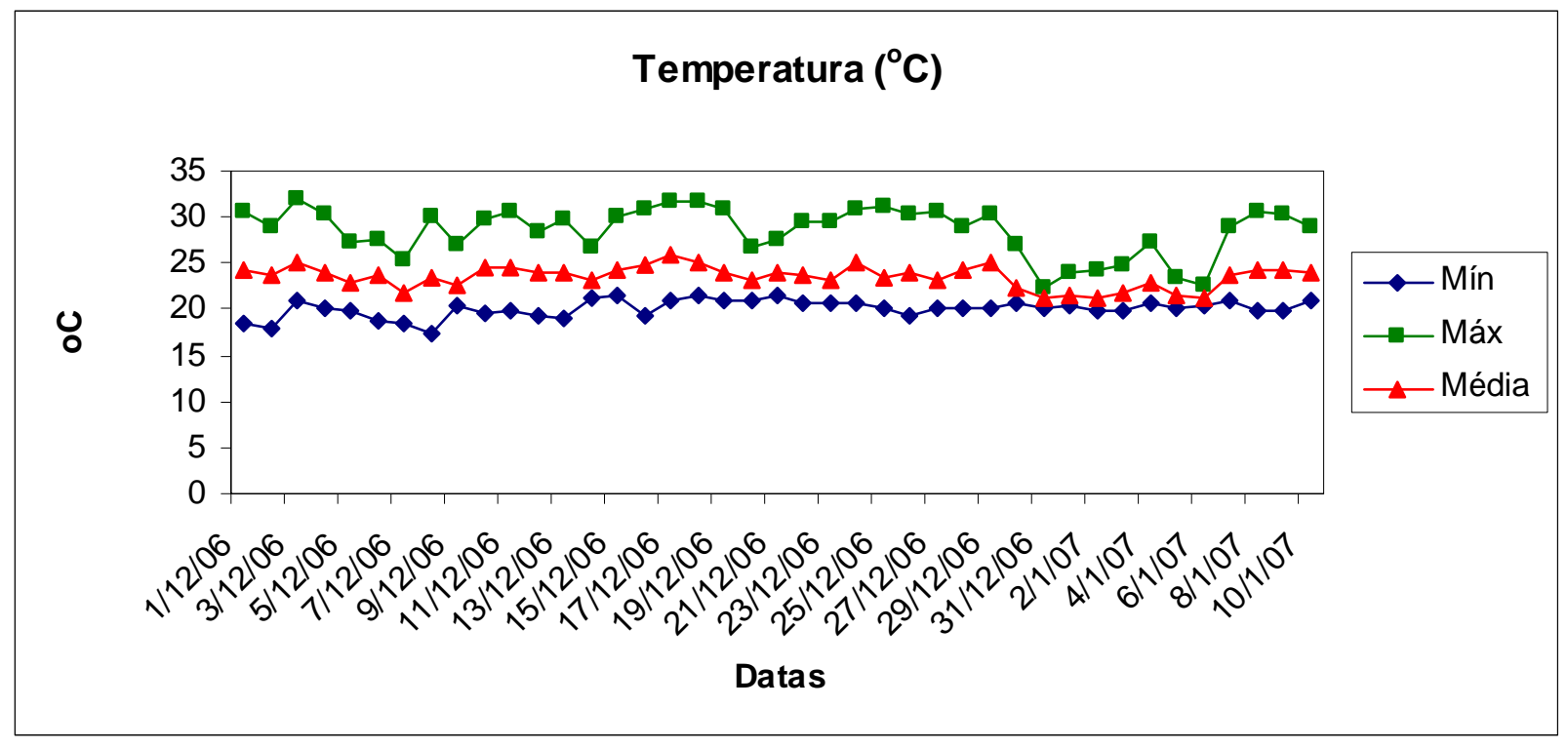

Figura 6. Temperatura $\left({ }^{\circ} \mathrm{C}\right)$ máxima, mínima e média durante o período experimental.

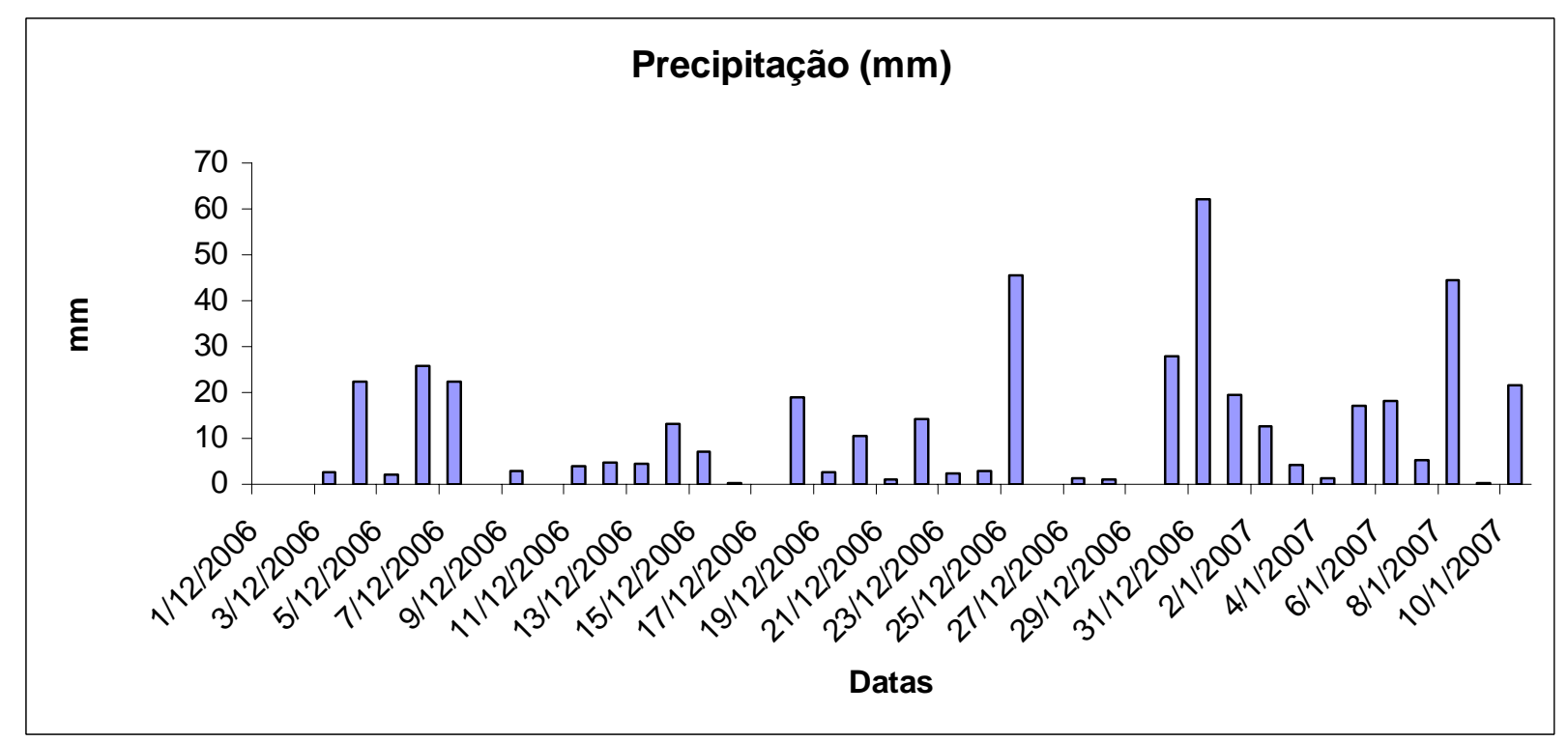

Figura 7. Precipitação $(\mathrm{mm})$ máxima, mínima e média durante o período experimental. 


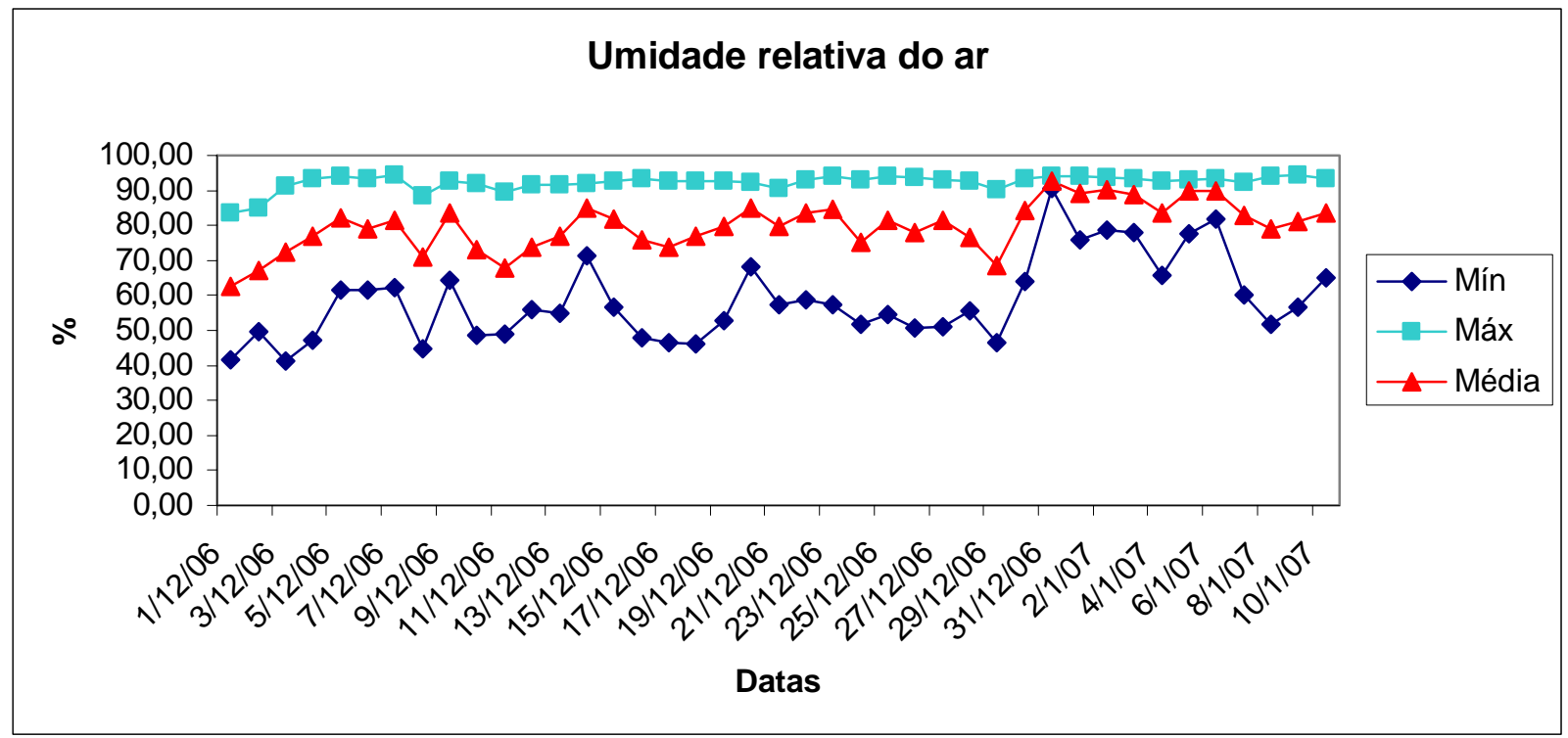

Figura 8. Umidade do ar(\%) máxima, mínima e média durante o período experimental.

\subsubsection{Delineamento experimental}

Empregou-se o delineamento em blocos completos casualizados, com dez tratamentos e quatro repetições (Figura 9) totalizando 40 parcelas experimentais, sendo dois tratamentos controles sem a aplicação de $N(0 \mathrm{~kg}$ ha $^{-1}$ de $\mathrm{N}$ no milho). Cada parcela experimental constitui-se de 6 linhas de milho de 0,80 metros de espaçamento e 10 metros de comprimento, totalizando área de $48 \mathrm{~m}^{2}$.

As avaliações foram realizadas nas quatro linhas centrais considerandose como área útil, sendo que uma linha em cada lateral da parcela foi considerada bordadura, desprezando-se 1,0 m em cada extremidade. 


\begin{tabular}{|c|c|c|c|c|c|c|c|c|c|c|}
\hline Bloco I & T5 & T4 & T6 & T8 & T3 & T10 & T2 & T1 & T7 & T9 \\
\hline Bloco II & T5 & T8 & T2 & T4 & T3 & T9 & T6 & T7 & T1 & 10 \\
\hline Bloco III & T9 & T3 & T2 & T10 & T4 & T8 & T5 & T7 & T6 & T1 \\
\hline Bloco IV & T2 & T3 & T4 & T1 & T5 & T10 & T6 & T9 & T7 & T8 \\
\hline
\end{tabular}

Figura 9. Croqui e área útil do experimento.

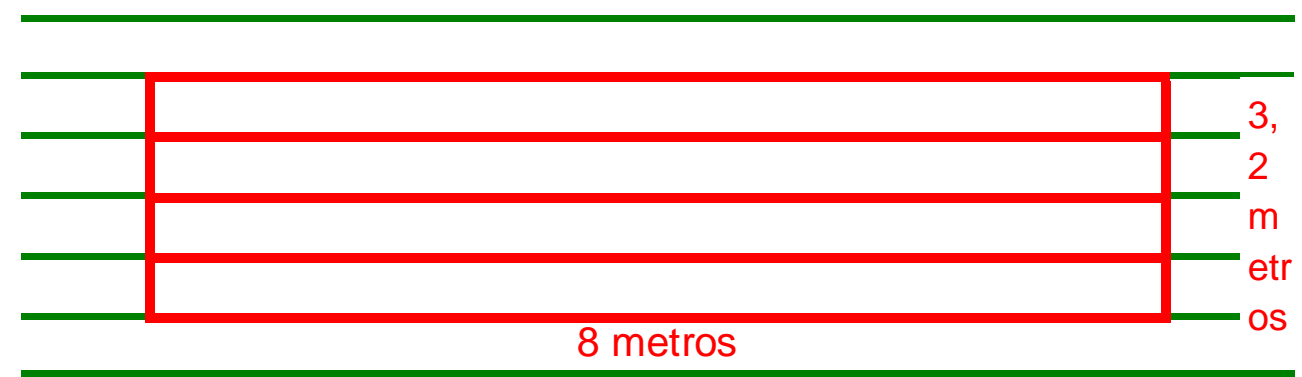

10 metros

Espaçamento de 0,80 m entre linhas de milho

Tamanho da parcela : $10 \mathrm{~m} \times 6$ linhas $\times 0,8 \mathrm{~m}=48 \mathrm{~m}^{2}$

Tamanho do experimento: $48 \mathrm{~m}^{2} \times 24$ parcelas $=1152 \mathrm{~m}^{2}$

\subsubsection{Tratamentos}

Os tratamentos avaliados no experimento foram de caráter qualitativo. Trabalhou-se com fontes de nitrogênio aplicadas em cobertura na dose correspondente a $100 \mathrm{~kg} \mathrm{ha}^{-1}$ de $\mathrm{N}$ em cobertura. Os tratamentos empregados no experimento são apresentados na Tabela 4. 
Tabela 4. Tratamentos experimentais utilizados no presente trabalho para verificar à eficiência das fontes nitrogenadas quanto a composição químico-bromatológico e algumas características agronômicas.

\begin{tabular}{|c|c|c|c|c|c|c|c|c|c|}
\hline \multirow[b]{2}{*}{ Tratamentos } & \multirow[b]{2}{*}{ Especificação } & \multicolumn{2}{|c|}{ Dose e fontes de $\mathrm{N} \mathrm{Kg/ha}$} & \multicolumn{2}{|c|}{ Dose e fontes de S Kg/há } & \multicolumn{4}{|c|}{ Quantidade Kg/tratamento } \\
\hline & & N em cobertura & Fonte & S em cobertura & Fonte & Uréia & NA & SAM & Gesso FASN \\
\hline 1 & Testemunha + Gesso $(-\mathrm{N}+\mathrm{S})$ & 0 & 0 & 53,8 & 385 & & & & 7,385 \\
\hline 2 & Testemunha absoluta (-N -S) & 0 & 0 & 0 & 0 & & & & \\
\hline 3 & Uréia - 45\% N & 100 & 222 & 0 & 0 & 4,267 & & & \\
\hline 4 & Uréia + Gesso (14\% S) & 100 & 222 & 53,8 & 385 & 4,267 & & & 7,385 \\
\hline 5 & Uréia + Sulfato de Amônio - 21\%N/24\%S - (33:00:00+12\%S)* & 100 & 303 & 53,8 & 0 & 2,909 & & 2,909 & \\
\hline 6 & Nitrato de Amônio - NA - 30\%N & 100 & 333 & 0 & 0 & & 6,4 & & \\
\hline 7 & Nitrato de Amônio - NA - 30\%N + Gesso & 100 & 333 & 53,8 & 385 & & 6,4 & & 7,385 \\
\hline 8 & NA + Sulfato de Amônio - 21\%N/24\%S - $(27,8: 00: 00+6 \% S)^{\star *}$ & 100 & 333 & 20 & 0 & & 4,8 & 1,6 & \\
\hline 9 & SAM - 21\%N/24\%S & 100 & 476 & 114,3 & 0 & & & 9,143 & \\
\hline 10 & FASN (26\%N e 14\%S) & 100 & 385 & 53,8 & 0 & & & & 7,385 \\
\hline
\end{tabular}

* T-5 Mistura de 500kg Uréia + 500kg Sulfato de amônio. ** T-8 Mistura de 750kg NA + 250kg Sulfato de amônio. Fonte 2 - Gesso.

Foi utilizado como fonte de enxofre o Gesso. Observação: A dose de $\mathrm{K}_{2} \mathrm{O}$ foi definida com base na análise química do solo. 


\subsubsection{Adubação de plantio e semeadura do milho}

A adubação de plantio e a semeadura foram realizado no dia 07/11/2006, com $450 \mathrm{~kg}$ ha de 8:28:16+0,5\%Zn e a semedura foi realizada mecanicamente com semeadora apropriada (Figura 10) para o sistema de plantio direto (SPD), com espaçamento de 0,80 $\mathrm{m}$ entre as linhas e uma profundidade de 4 a $5 \mathrm{~cm}$, com uma população de 60.000 plantas por hectare. Não foi observada discrepância no estande de plantas. A área experimental apresentava-se praticamente plana.

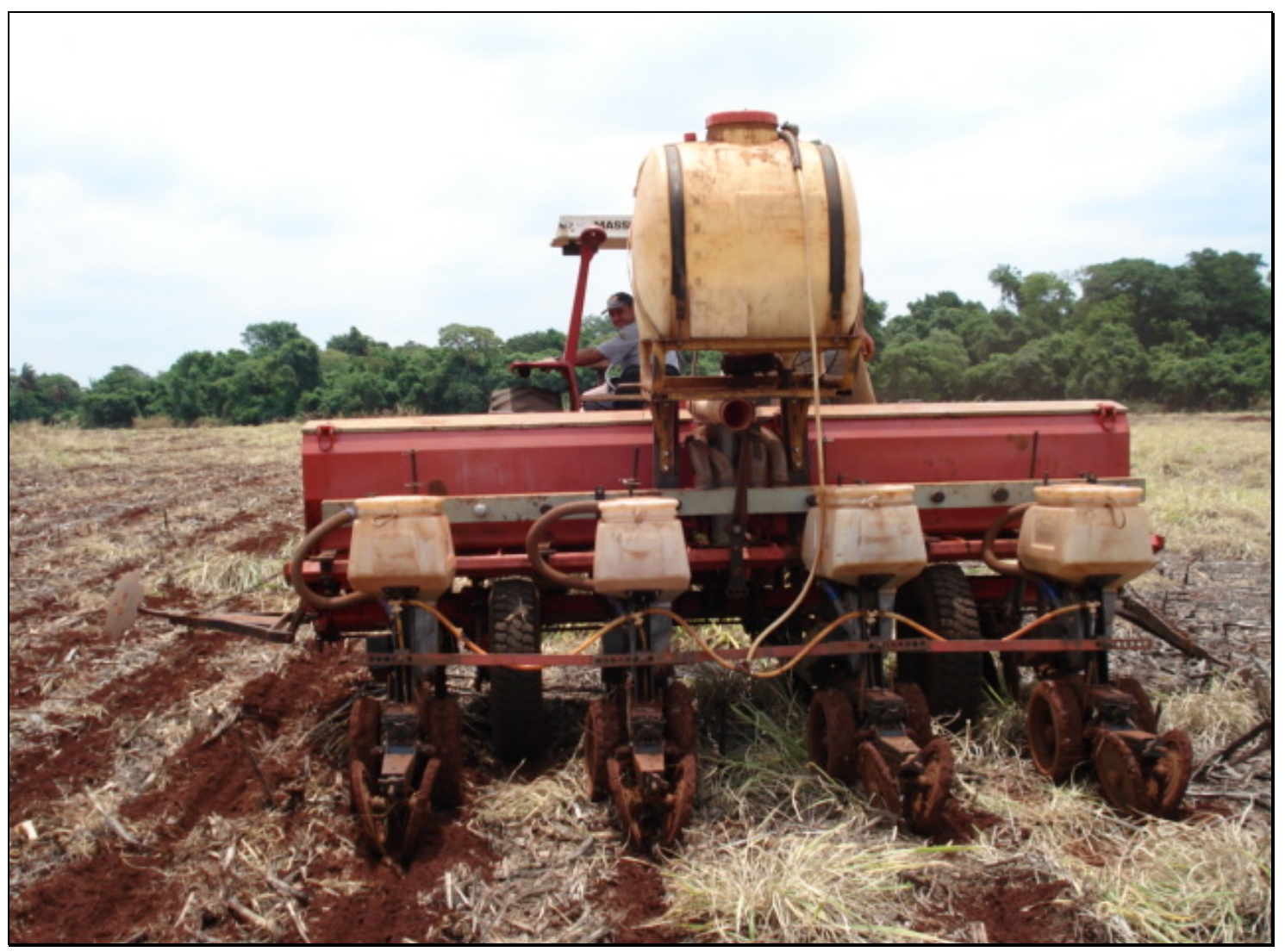

Figura 10. Adubação de plantio e semeadura de milho. 


\subsubsection{Adubação de cobertura e tratos culturais do milho}

A adubação de cobertura foi realizada manualmente no dia 16/12/2006, com idade das plantas de 39 dias, Figuras 11 e 12 , com aplicação de Uréia, Gesso, Sulfato de amônio, Nitrato de amônio e FASN, quando a cultura apresentava sete a oito folhas expandidas (estádios V7 e V8). Não se observou o desenvolvimento de plantas daninhas, em pontos isolados mesmo com a presença da palha na superfície do solo. Porém não foi utilizado nenhum método para controle pois o mato surgiu em pontos isolados. Durante o período de condução do experimento no campo, realizou-se apenas limpeza nos espaços existentes entre as parcelas de cada bloco, formando pequenos "carreadores" que facilitou a locomoção entre as parcelas durante as avaliações. O experimento foi conduzido no período de Dezembro de 2006 a Junho de 2007. 


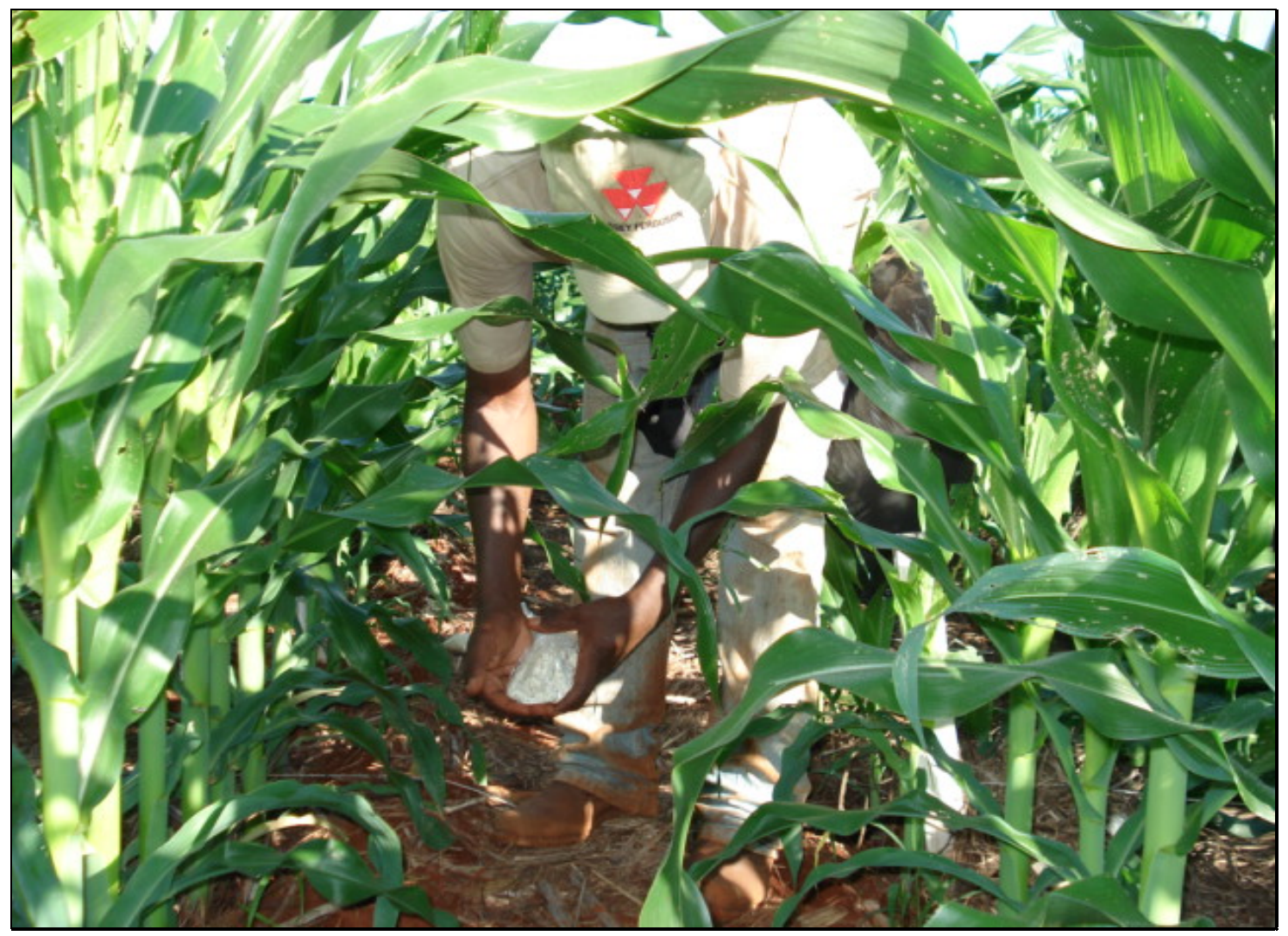

Figura 11. Adubação de cobertura no milho.

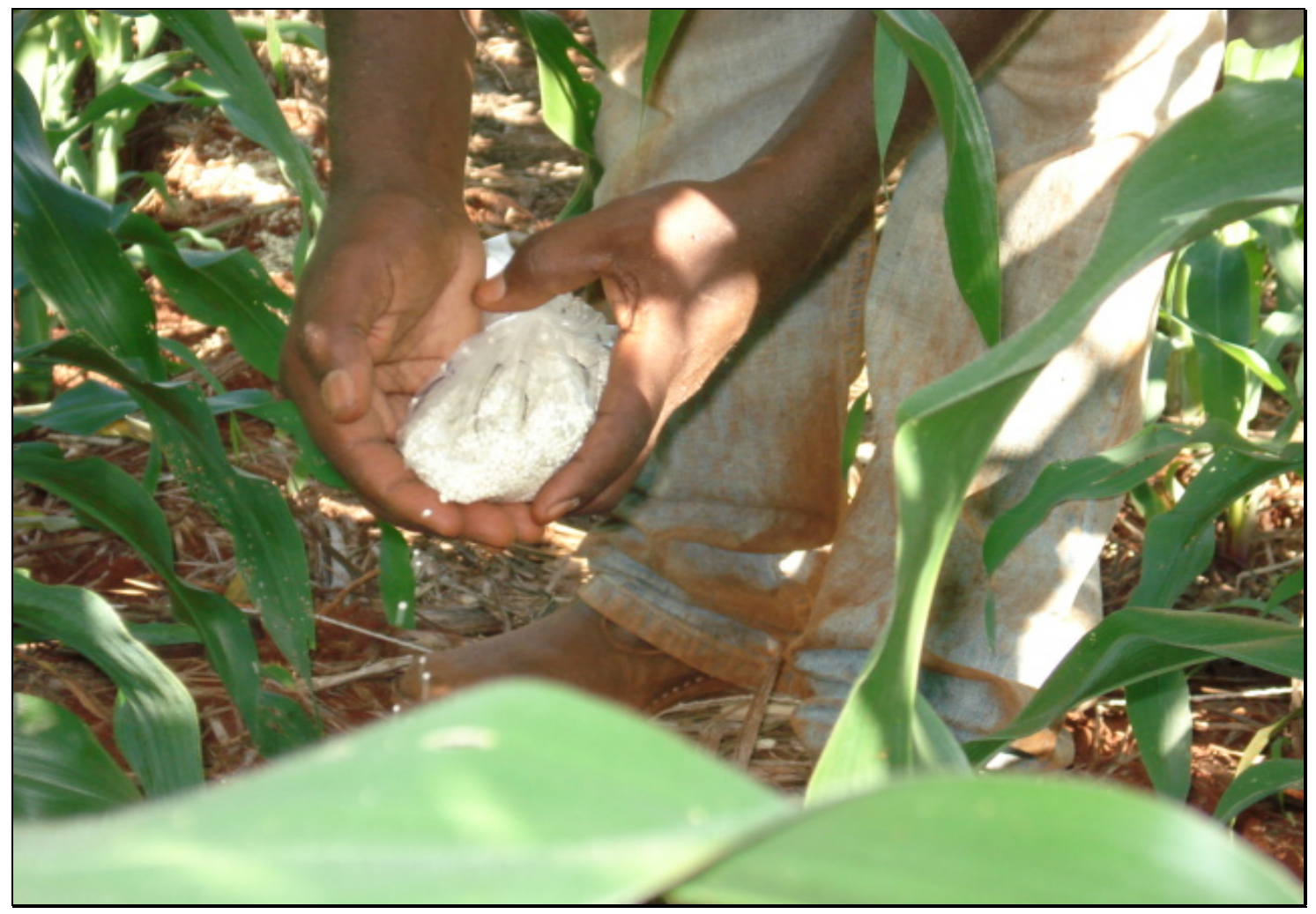

Figura 12. Adubação de cobertura no milho. 


\subsubsection{Característica do híbrido utilizado}

O cultivar utilizado foi o GNZ-2005: híbrido simples, ciclo superprecoce, plantio normal, utilizado para a produção de grãos e altamente resistente ao acamamento. É muito resistente à ferrugens (Puccinia sorghi, P. Polyssora e P. Physopella) Phaeosphaeria maydis, fusariose, enfezamento e doenças de grãos. Para o controle da Spodoptera frugiperda (lagarta do cartucho) foi utilizado o inseticida Deltamethrin na dose de $75 \mathrm{~mL} \mathrm{ha}^{-1}$. O tratamento de sementes foi realizado com inseticida no sulco de plantio com aplicação de Clorpirifós a 0,8 litros/ha.

As Características do Hibrido são: tipo modificado; Ciclo superprecoce; Florescimento: média 55 dias; Soma térmica: 820 UC; Finalidade: grãos; Arquitetura da planta: Folhas semi-eretas, cor verde escuro e espigas proeminentes; Tipo de grão: semi duro alaranjado; Peso específico: 795 kg/m³; Tipo de espiga: Cilíndrica, tamanho grande, média de 16 fileiras de grãos, sabugo fino e de cor branca; Doenças foliares: Phaeosphaeria maydis; População de plantas: Verão - 60. 000 a 65. 000 pl/ha, safrinha - 45. 000 a 50. $000 \mathrm{pl} / \mathrm{ha}$; Época de plantio: recomendado para plantio na Safra Verão e Safrinha; Espaçamento limite: Não há restrições ao espaçamento entre linhas dentro da faixa de $0,45-0,90 \mathrm{~m}$, desde que se mantenha a população recomendada; Regiões de adaptação: Centro-Oeste, Sudeste, Sul e Bahia; Pontos fortes: - Precocidade, - Elevado potencial produtivo, - Ampla adaptação geográfica, - Tolerância ás principais doenças foliares, - Flexibilidade de época de plantio, - Ótima relação custo/benefício, - Resposta à melhoria do manejo, Excelente arquitetura foliar, - excelente desempenho na safrinha. 


\subsubsection{Determinação das perdas de $\mathrm{N}-\mathrm{NH}_{3}$}

Nos tratamentos em que se avaliou as perdas por volatilização de $\mathrm{N}$ $\mathrm{NH}_{3}$, primeiramente enterrou-se as bases dos coletores de amônia (Figura 13). Posteriormente aplicou-se o adubo nitrogenado, manualmente e de forma localizada em cada parcela, procurando-se colocar as fontes a $25 \mathrm{~cm}$ de distância das linhas de milho. Para viabilizar a determinação da amônia volatilizada por meio dos coletores, buscou-se máxima uniformidade de aplicação das fontes nitrogenadas. Aplicou-se nas bases dos coletores quantidades previamente pesadas ou medidas das fontes sólidas e fluidas. No mesmo dia em que as fontes nitrogenadas foram aplicadas, instalou-se os coletores semi-aberto estáticos para determinação das perdas gasosas de $\mathrm{N}$ $\mathrm{NH}_{3}$.

No período de 20 de dezembro a 10 de janeiro de 2007, quantificou-se as perdas de $\mathrm{N}^{-\mathrm{NH}_{3}}$ por volatilização por meio do coletor semi-aberto desenvolvido por Nonmik (1973) com as adaptações realizadas por Lara Cabezas et al. (1999). Cada parcela dos tratamentos T1, T2, T3, T4, T5, T6, T7, T8, T9 e T10 utilizou um coletor com 5 bases (Figura 14) iguais nas quais aplicou-se as fontes nitrogenadas na dose equivalente a $100 \mathrm{~kg} \mathrm{ha}^{-1}$ de $\mathrm{N}$. 


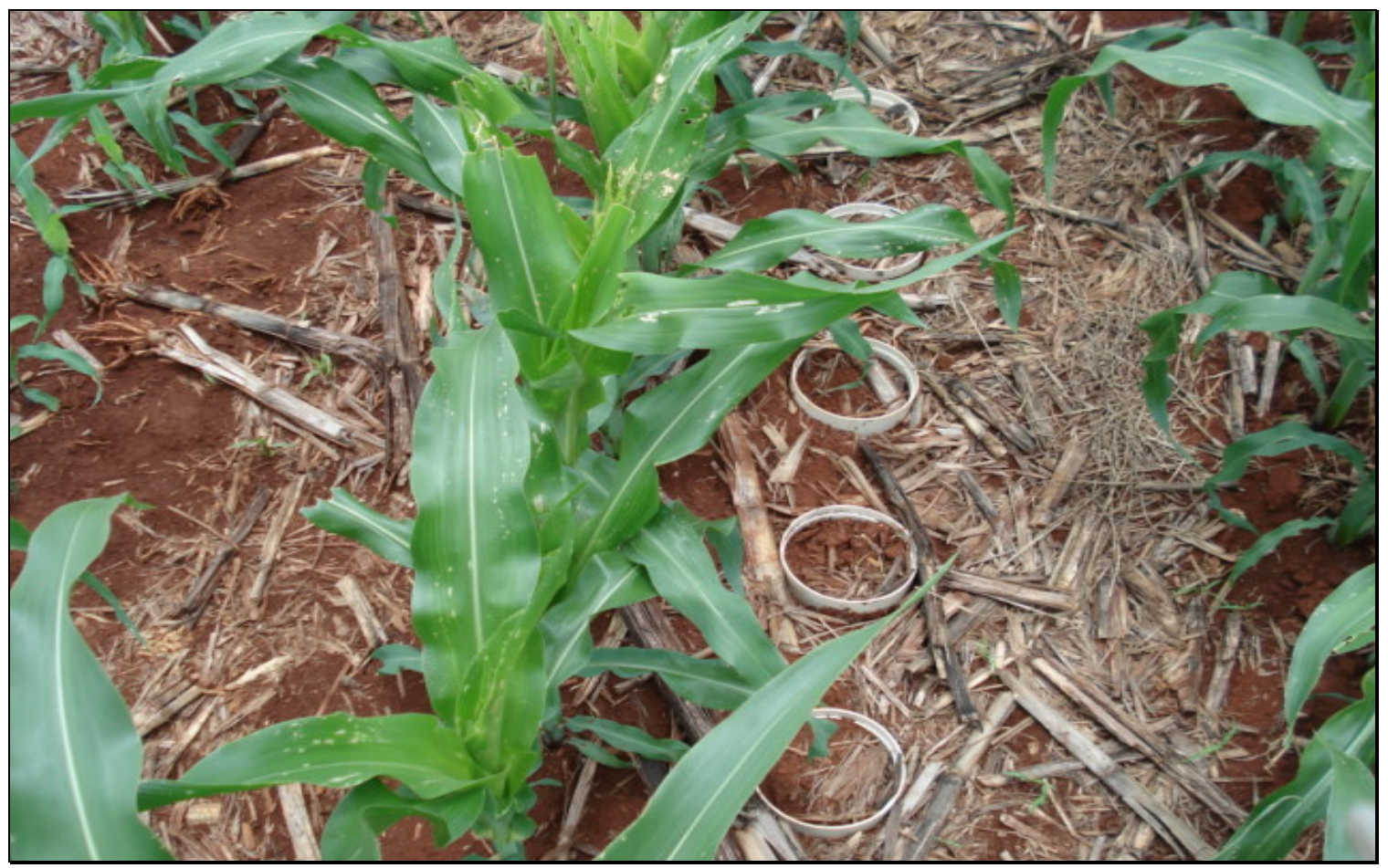

Figura 13. Detalhe das bases para mudança de posição dos coletores.

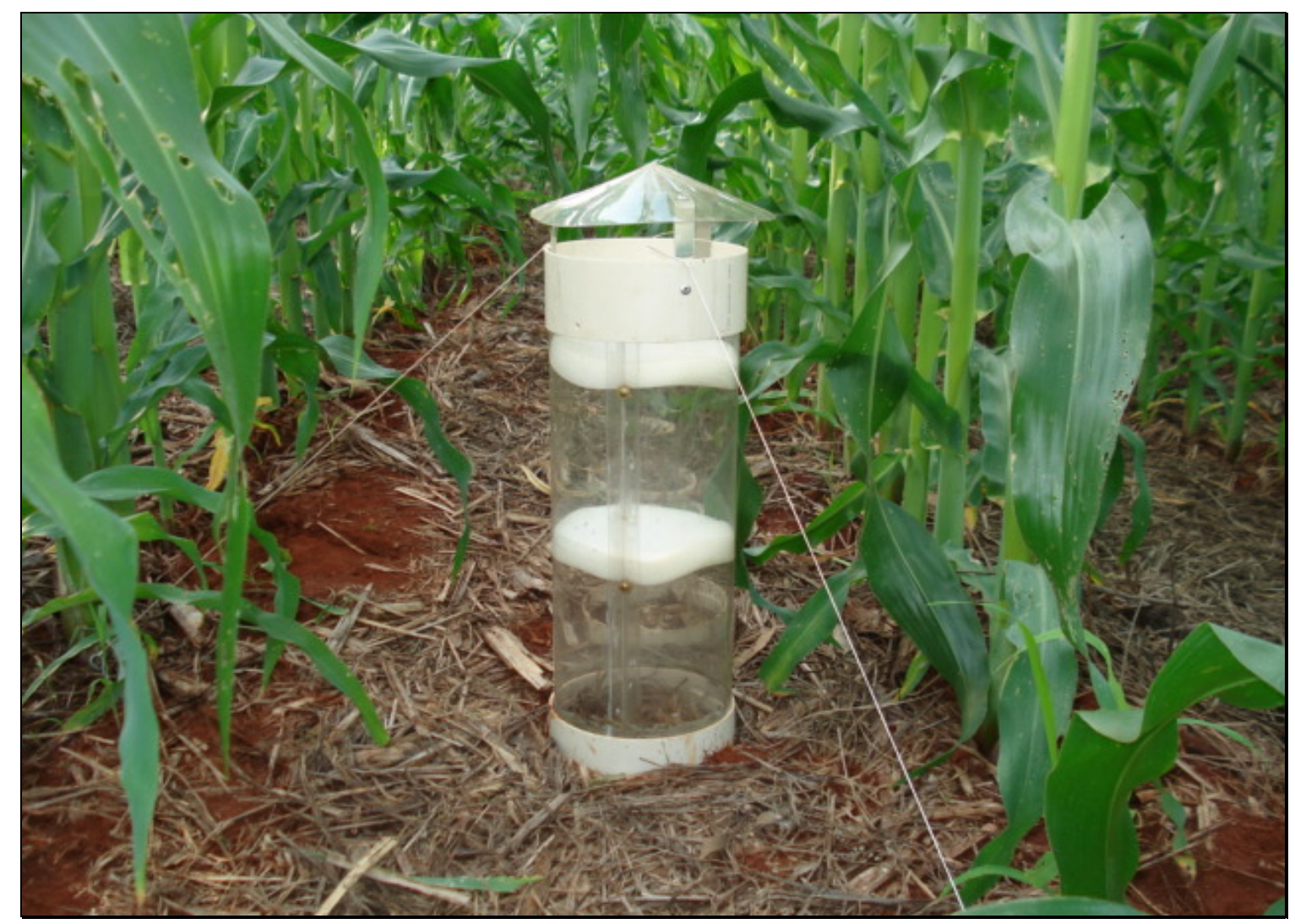

Figura 14. Detalhe dos coletores de amônia instalados no campo. 
Cada coletor apresentava suportes (Figura 14) no seu interior para sustentar duas espumas (densidade $0,02 \mathrm{~g} / \mathrm{cm}^{3}$ ), que antes de serem instaladas nos coletores foram embebidas com $30 \mathrm{~mL}$ de solução de ácido fosfórico $(0,5 \mathrm{~N})$ (Figura 15) e glicerina (3\% v/v) com objetivo de absorver o N$\mathrm{NH}_{3}$. Em seguida foram deixados em sacos plásticos até o momento da sua colocação nos coletores. A espuma superior, posicionada a $31 \mathrm{~cm}$ do solo, permite a coleta da $\mathrm{N}-\mathrm{NH}_{3}$ da atmosfera, evitando que a espuma inferior $(15,5$ $\mathrm{cm}$ do solo), que capta $\mathrm{o} \mathrm{N}-\mathrm{NH}_{3}$ volatilizado da superfície do solo, fosse contaminada (Lara Cabezas \& Trivelin, 1990). Em cada período de amostragem, novas espumas embebidas em ácido fosfórico e glicerina foram utilizadas conforme procedimento indicado acima.

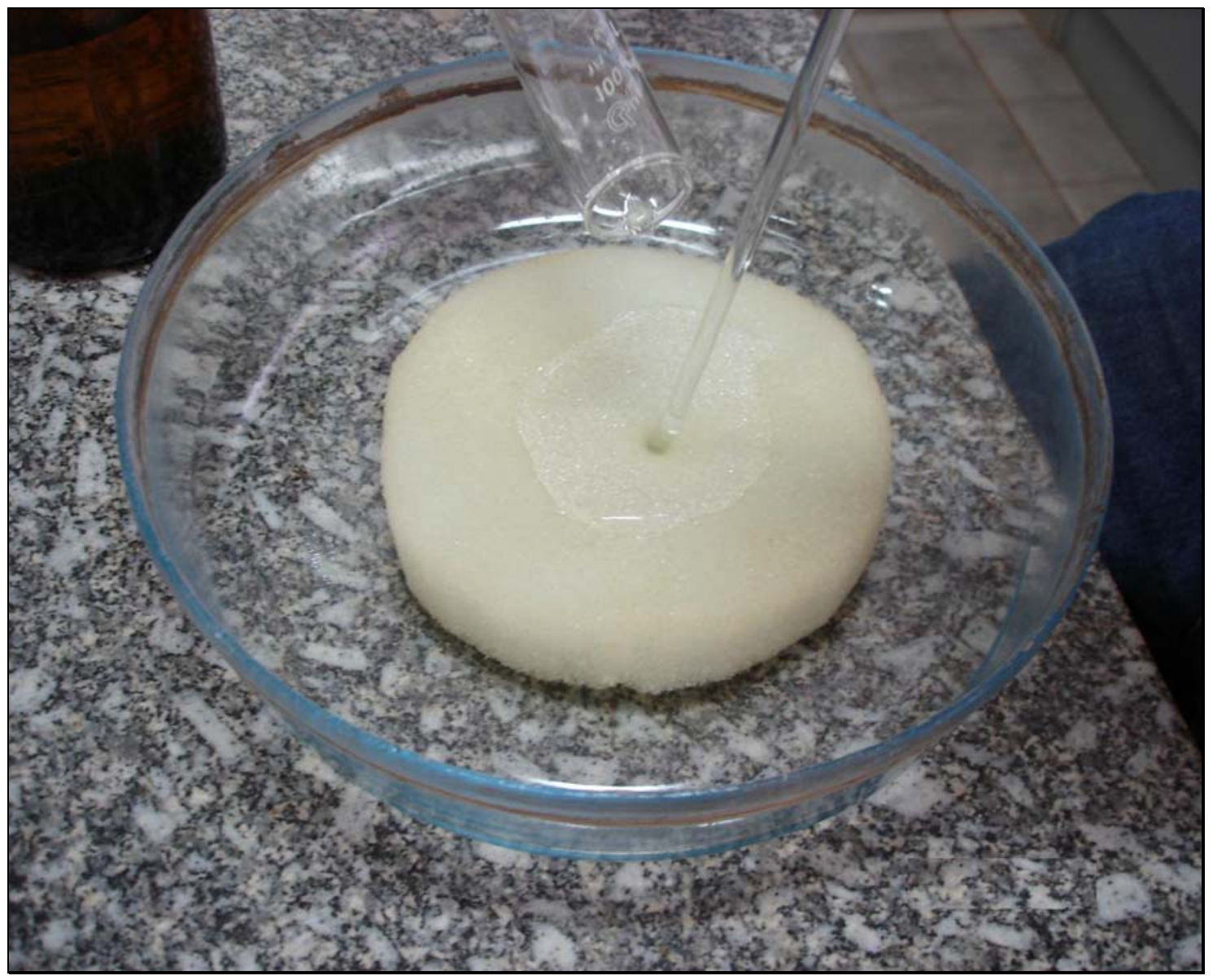

Figura 15. Embebimento das espumas do coletor semi-aberto com ácido fosfórico. 
Foram planejadas oito épocas para a determinação de $\mathrm{N}-\mathrm{NH}_{3}$ volatilizado 2, 4, 6, 8, 12, 16, 19 e 23 dias depois da adubação, em razão das fortes chuvas nos dias subseqüentes à adubação, o protocolo de amostragem não foi alterado depois da adubação, uma vez que chuvas superiores a 10 a 20 $\mathrm{mm}$ reduzem, substancialmente, o processo de volatilização de $\mathrm{N}-\mathrm{NH}_{3}$ (Black et al., 1987). No período de avaliação não colocou-se água dentro dos coletores de $\mathrm{N}-\mathrm{NH}_{3}$, em quantidades equivalentes ás chuvas registradas no período (cerca de $70 \mathrm{~mm}$ ), no intuito de evitar erros decorrentes de diferenças na umidade do solo dentro e fora dos coletores, conforme proposto por Lara Cabezas et al. (1999).

Cada coletor apresentou duas espumas absorventes (Figura 16). A espuma inferior foi utilizada para determinar a amônia proveniente do solo e das fontes nitrogenadas e a espuma superior foi utilizada para isolar a espuma inferior do contato com atmosfera. A cada coleta e troca, os coletores foram transferidos para as bases subseqüentes, de modo que, a determinação de cada período foi realizada considerando-se as influências de mudanças climáticas ocorridas (chuva, orvalho, vento, temperatura). 


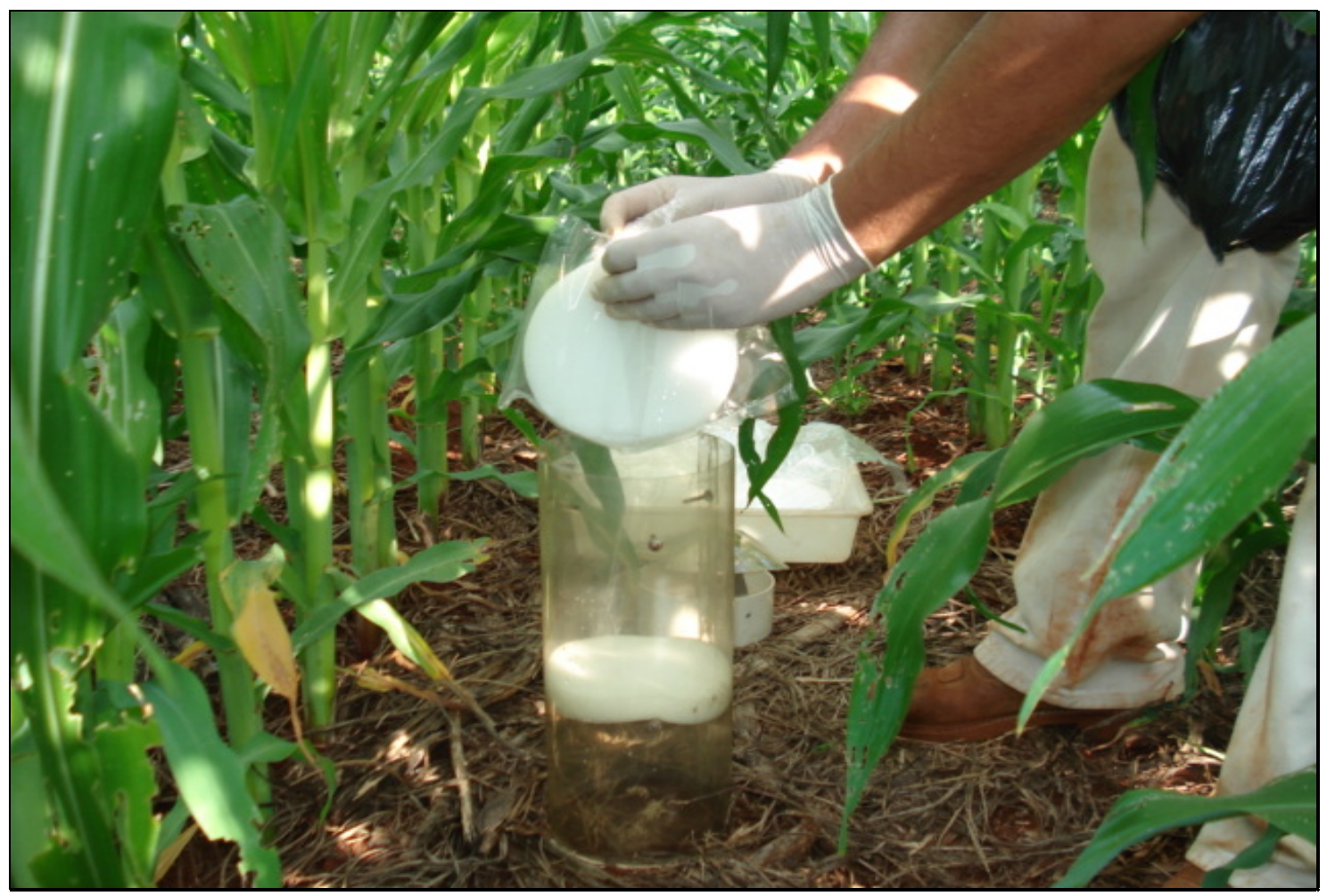

Figura 16. Detalhe de troca de espumas embebidas em solução de ácido fosfórico.

Em cada período de coleta, as espumas inferiores, que captaram o N$\mathrm{NH}_{3}$ volatilizado do solo, foram acondicionadas em sacos plásticos devidamente identificados, que foram vedados e armazenados sob refrigeração de $1{ }^{\circ} \mathrm{C}$ até o momento da análise (Figuras 17). No laboratório as espumas foram retiradas, individualmente, do freezer para a extração forçada de $\mathrm{N}-\mathrm{NH}_{3}$. Cada espuma foi colocada sobre um funil de porcelana (Figura 18) e, com o auxílio de uma bomba de váculo, lavou-se a espuma, com aproximadamente, $400 \mathrm{~mL}$ de água deionizada. Durante o processo de extração, os materiais que entraram em contato com a espuma também foram lavados com água deionizada para evitar possíveis perdas do $\mathrm{N}-\mathrm{NH}_{3}$ coletado no campo. 


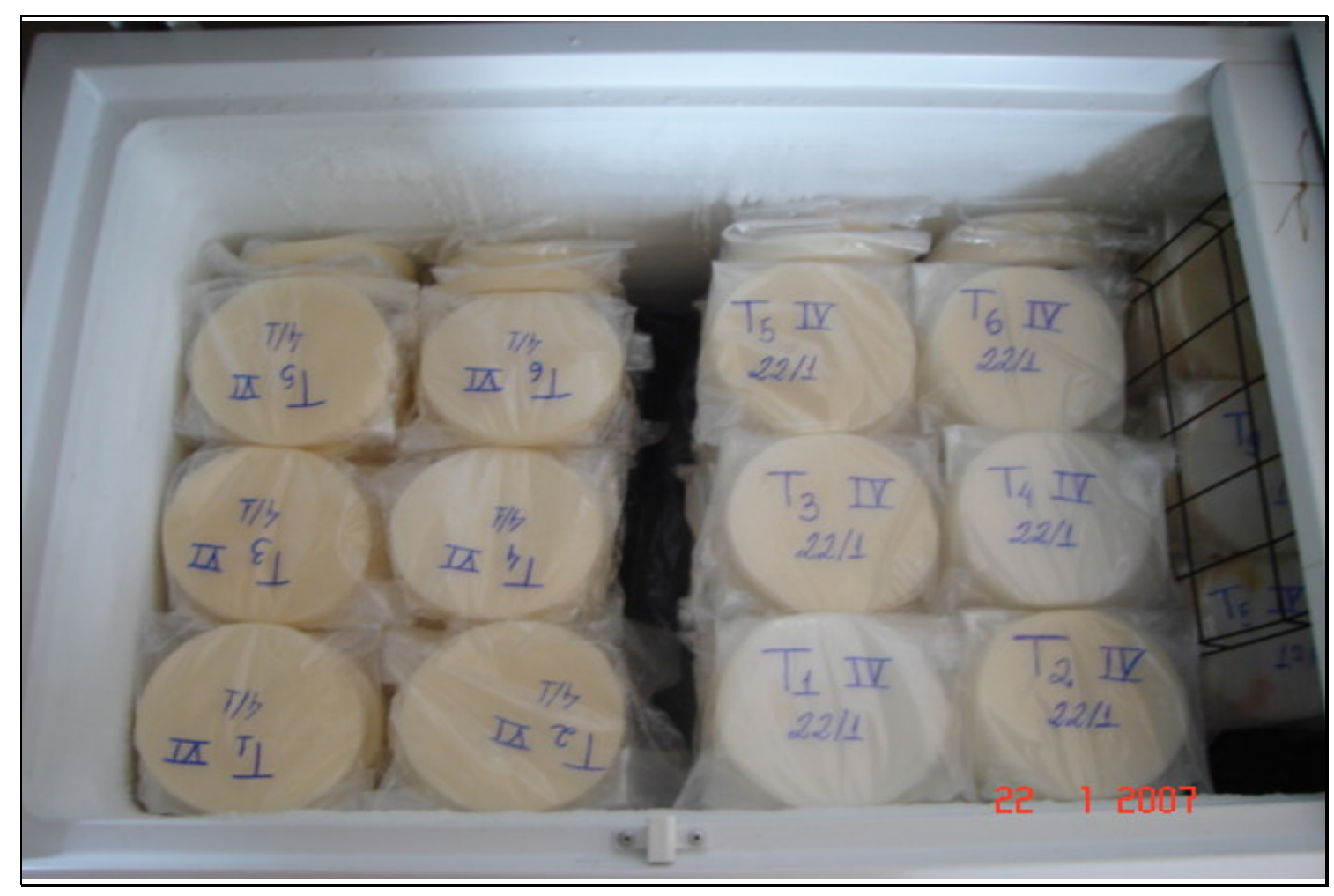

Figura 17. Espumas que contém amônia depois da sua retirada no campo e condicionadas sobre a refrigeração.

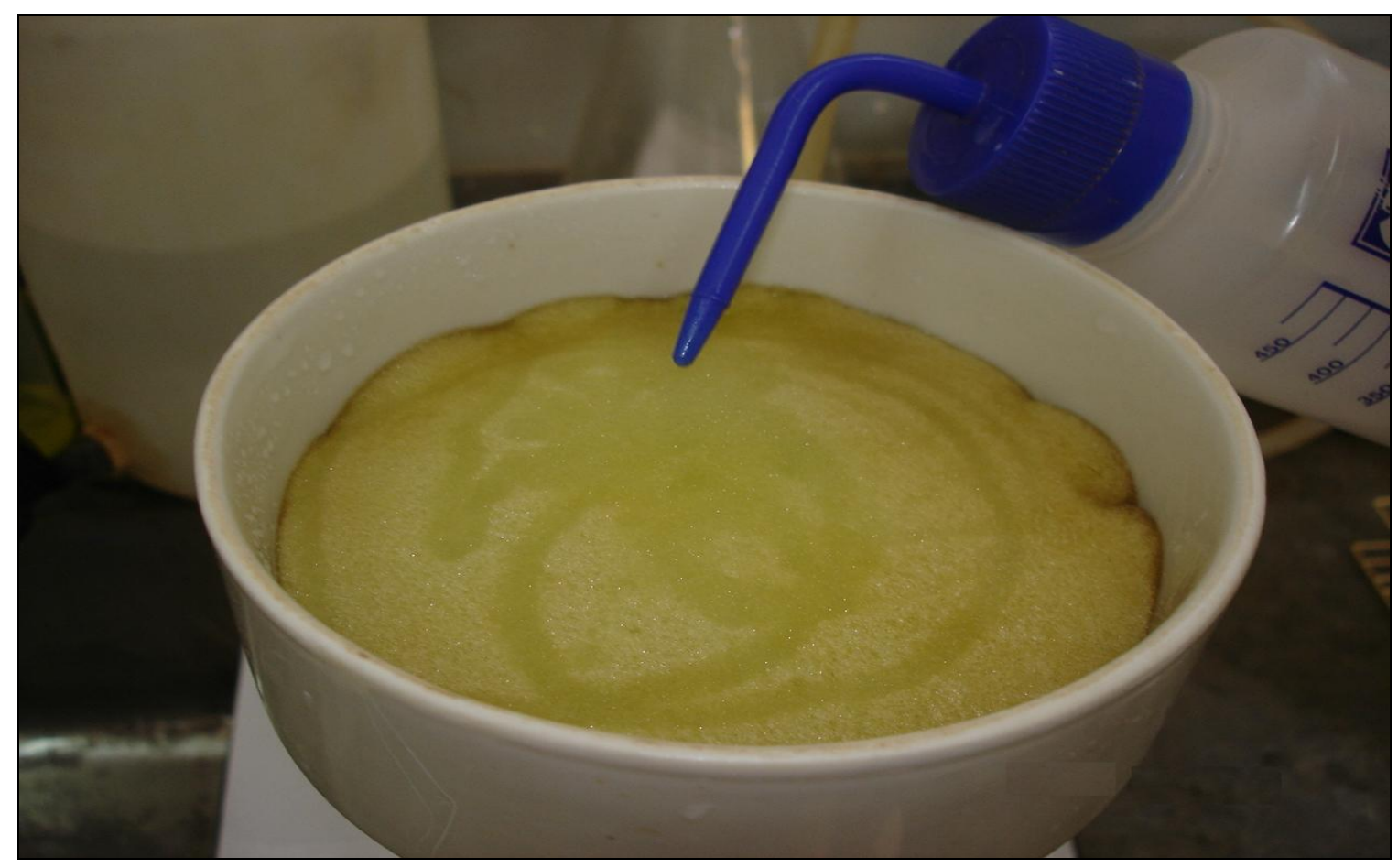

Figura 18. Lavagem da espuma sobre o funil de porcelana para a retirada da amônia. 
Além disso, todo o processo foi feito com o auxílio de uma pinça, no sentido de evitar a contaminação do material a ser analisado. Entre a extração de $\mathrm{N}-\mathrm{NH}_{3}$ de duas espumas sucessivas, todo o material foi lavado, primeiramente com água de torneira e, subseqüentemente, com água deionizada. A solução extraída de cada espuma (cerca de 388 a $425 \mathrm{~mL}$ ) foi acidificada com $10 \mathrm{~mL}$ de ácido clorídrico. A determinação de $\mathrm{N}^{-N_{3}}$ foi feita por destilação e titulação, sendo que a solução destilada foi embebida em ácido bórico 2\% e titulada com ácido clorídrico 0,1 N.

Tanto para preparo ou extração no laboratório, quanto para coleta e troca no campo, o manuseio das espumas foi extremamente cuidadoso, utilizando-se sacos plásticos para isolar as espumas da atmosfera e luvas de borracha, com objetivo de minimizar riscos de contaminação. Com objetivo de minimizar erros ocorridos por contaminação, também fez-se determinações em espumas que não foram levadas ao campo, que atuaram como provas em branco.

No extrato tomou-se alíquota de $15 \mathrm{ml}$ que foi transferida para balão de destilação (Figura 19), onde adicionou-se $\mathrm{NaOH}(40 \%)$ para elevar o $\mathrm{pH}$ da solução até 7,5. O destilado foi recolhido em Erlenmeyer contendo $10 \mathrm{ml}$ de solução de ácido bórico a 5\% mais indicador e, posteriormente foi titulado com ácido clorídrico a 0,02N para a titulação. Tendo-se em mão os valores do volume de ácido clorídrico gasto na titulação, das provas em branco e das amostras, calculou-se o nitrogênio amoniacal volatilizado pela equação $N=(V$ $a-V b) \times f$ de modo que:

$N=$ mg de nitrogênio

V a = Volume de ácido gasto na titulação da amostra

V $\mathrm{b}=$ Volume de ácido gasto na titulação do branco;

$\mathrm{f}=0,7$ (fator referente à molaridade do ácido, volume da alíquota e do extrato no balão volumétrico). 


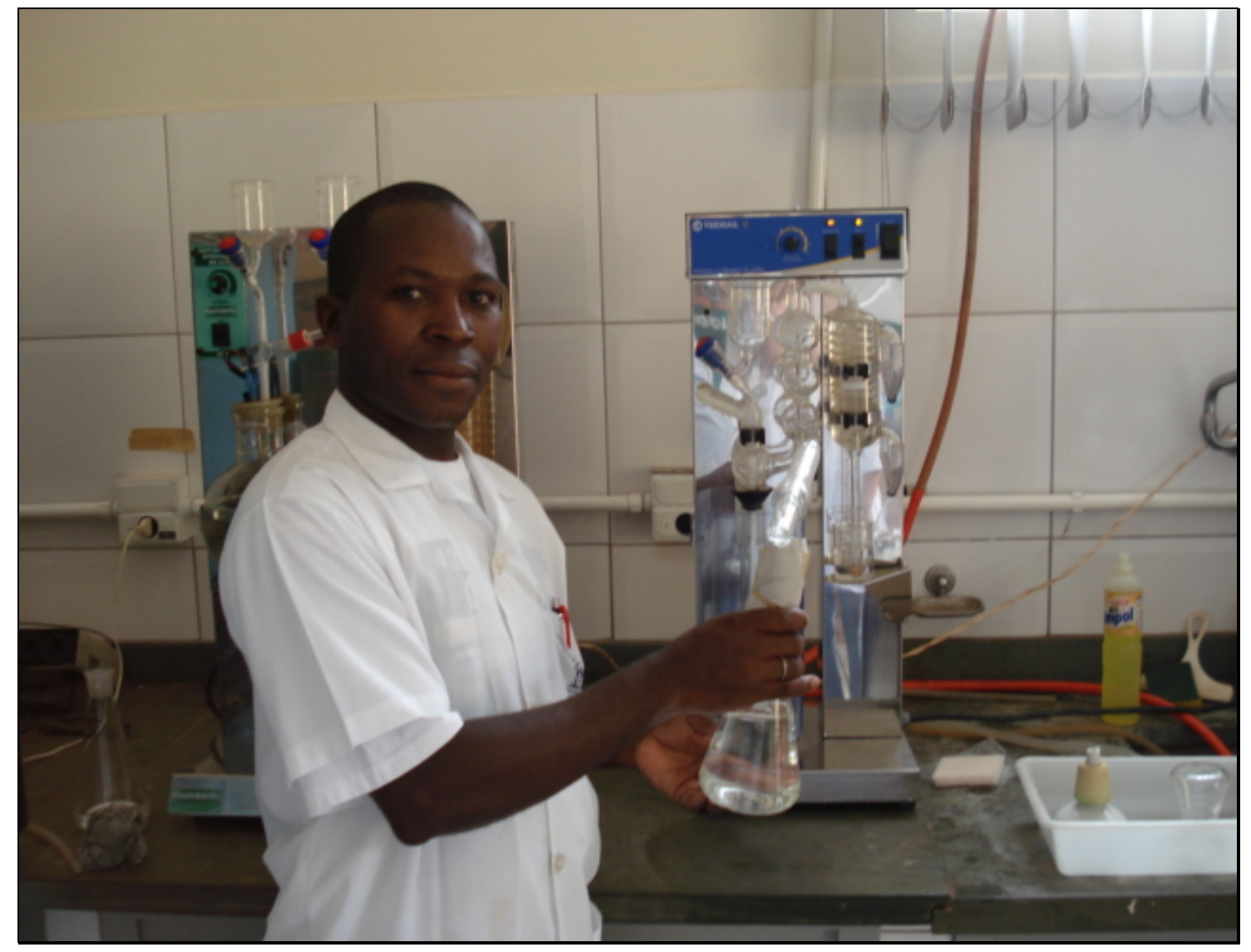

Figura 19. Destilação de amônia $\left(\mathrm{NH}_{3}\right)$.

Os resultados obtidos foram corrigidos de acordo com as equações propostas por Lara Cabezas et al. (1999). Uma das principais críticas a coletores fechados e semi-abertos de $\mathrm{N}-\mathrm{NH}_{3}$ refere-se à geração de condições artificiais no interior do coletor, o que prejudica os fluxos de $\mathrm{N}-\mathrm{NH}_{3}$ da superfície do solo para a atmosfera (Sharpe \& Harper, 1995), podendo ocorrer, inclusive, a reabsorção de $\mathrm{N}-\mathrm{NH}_{3}$ pelo solo. $\mathrm{Na}$ ausência de correção dos valores determinados de $\mathrm{N}-\mathrm{NH}_{3}$, os estudos com base no uso desses aparelhos não possibilitam quantificar as perdas de $\mathrm{N}-\mathrm{NH}_{3}$ que efetivamente ocorre no campo. 
Para a quantificação do $\mathrm{N}$ amoniacal, coletado nas espumas, utilizou-se a seguinte equação :

$\mathrm{N}$ amoniacal $=$ volume gasto de $\mathrm{HBO}_{3} \underline{x}$ normalidade do $\mathrm{HCl} \times$ massa atômica do $\mathrm{N}$

( peso da amostra/100)

HBO3 - ácido bórico

$\mathrm{HCl}$ - ácido clorídrico

$N$ - nitrogênio

\subsubsection{Estado nutricional das plantas de milho}

Avaliou-se o estado nutricional das plantas pela análise química de amostras foliares coletadas no florescimento (Büll, 1993). De cada linha central da parcela coletou-se 5 folhas abaixo e oposta da espiga, totalizando 20 folhas por tratamento. De acordo com o método de preparo de material descrito por Malavolta et al. (1997), as folhas amostradas foram armazenadas em sacos de papel identificados e levadas para o laboratório, retirou-se a nervura central e os terços inferiores e superiores das mesmas. Utilizou-se o terço médio das folhas após a secagem em estufa com circulação de ar a $65{ }^{\circ} \mathrm{C}$ durante 48 horas. Depois de resfriadas, as amostras foram moídas passadas em moinho tipo Wiley e submetidas à análise para a determinação de macro e micronutrientes, conforme método descrito por Malavolta et al. (1997). O N foi extraído pela digestão sulfúrica; $\mathrm{P}, \mathrm{K}, \mathrm{Ca}, \mathrm{Mg}, \mathrm{S}, \mathrm{Cu}, \mathrm{Fe}, \mathrm{Mn}$ e $\mathrm{Zn}$ foram extraídos pela digestão nítro-perclórica e o B foi extraído por meio de digestão seca. 


\subsubsection{Determinação de produtividade}

Antes da colheita do milho, foram tomadas em cada tratamento duas espigas para determinação da umidade (foi feita junto à fábrica de ração) no aparelho medidor de umidade universal da GEHAKA. As amostras foram tomadas nas seguintes datas 13/3/2007, 29/3/2007, 9/4/2007 e 12/4/2007. A colheita manual do experimento foi efetuada em 13 de abril de 2007. Para a determinação da produtividade, foram coletadas as quatro linhas centrais da área útil de cada parcela, desprezando-se um metro das extremidades.

\subsubsection{Análise do solo depois da colheita do milho}

Após a colheita de milho, foram coletadas amostras de solo nas quatro linhas úteis, nas profundidades de 0-20 e 20-40, para a formação de uma amostra composta. As amostras foram acondicionadas em sacos plásticos, identificadas e encaminhadas para o Laboratório de solos das Ciências Agrarias, onde foram secas em estufa de circulação forçada, com temperatura de $60{ }^{\circ} \mathrm{C}$. Após a secagem, foram feitas determinações de $\mathrm{pH}, \mathrm{M} . \mathrm{O}, \mathrm{K}, \mathrm{Ca}, \mathrm{Mg}$, $\mathrm{H}+\mathrm{Al}$ e micronutrientes conforme métodos propostos por Raij et al. (1987). Também foram realizadas determinações de teores de enxofre (S) no solo. 


\subsection{Variáveis avaliadas}

\subsubsection{Massa seca total (mst, g)}

As amostras foliares foram coletadas no florescimento aos 73 dias após da semeadura (Büll, 1993). De cada linha central da parcela coletaram-se 5 folhas abaixo e oposta da espiga, totalizando 20 folhas por tratamento. Foram colocadas em saco de papel devidamente identificado, retirando-se a nervura central e os terços inferiores e superiores da mesma. Utilizou-se o terço médio das folhas após a secagem em estufas com circulação de ar a $65{ }^{\circ} \mathrm{C}$ durante 48 horas. A matéria seca de cada tratamento foi obtida em balança digital, após o resfriamento das amostras. A massa seca total (mst, g) foi constituída pelo somatório das massas individuais de folhas.

\subsubsection{Número de plantas}

Antes da colheita foi obtida a variável número de plantas, na área útil das parcelas, sendo os resultados expressos em número de plantas por hectare. A contagem de número de plantas foi feita por bloco, depois fez-se a soma do total de plantas de cada tratamento em estudo.

Após a colheita manual, foram pesadas as espigas da área útil das parcelas, com sabugo posteriormente debulhadas em uma máquina manual, e os grãos foram colocados em sacos em seguida pesados.

\subsubsection{Rendimento de grãos ( $\left.\mathrm{rg}, \mathrm{kg} \mathrm{ha}^{-1}\right)$}

O rendimento de grão foi obtido após a colheita das espigas de todas as plantas da área de amostragem de cada parcela. Posteriormente, realizou-se a debulha no moinho manual e a determinação da matéria úmida de grãos. Depois da debulha de grãos efetuou-se a correção do grau de umidade para $130 \mathrm{~g} \mathrm{~kg}^{-1}$ (13\%), visando à comparação das médias dos tratamentos na mesma base, quanto ao teor de água, conforme a expressão.

$\mathrm{M} 13=[\mathrm{MU} \times(1-\% \mathrm{U} / 100) / 0,87]$ 
Em que, M13 corresponde a massa de grãos (g) corrigida para o mesmo teor de água $130 \mathrm{~g} \mathrm{~kg}^{-1}$ (13\%), MU consiste na massa de grãos úmida (g) e U é a umidade da massa de grãos de cada parcela (\%).

\subsubsection{Proteína bruta (PB)}

As amostras foram moídas em moinho Willey equipado com peneira de 40 mesh. A percentagem de PB foi determinada digerindo-se $0,2 \mathrm{~g}$ de amostra de milho com $\mathrm{H}_{2} \mathrm{SO}_{4}$ e mistura de digestão $\left(\mathrm{Na}_{2} \mathrm{SO}_{4}\right.$ e $\left.\mathrm{CuSO}_{4} .5 \mathrm{H}_{2} \mathrm{O}\right)$, e posteriormente destilando com $\mathrm{NaOH}$ em destilador de arraste de vapor semimicro Kjeldahl (Tedesco et al., 1985). O fator de conversão 6,25 é normalmente usado para transformar a \% de nitrogênio em proteína, levandose em conta que as proteínas contém, em média, 16\% de nitrogênio.

Para a percentagem de proteína bruta (PB) avaliou-se o teor de nitrogênio, utilizando-se o aparelho de destilação a vapor micro-Kjedahl, conforme AOAC (1970), o teor de proteína bruta foi calculado utilizando-se o fator de conversão 6,25.

\subsubsection{Teor de fibra em detergente ácido e em detergente neutro (FDA e FDN) no grão de milho}

Foi determinada em todos os tratamentos depois da coleta final do milho, onde foram moídas os grãos de cada tratamento, segundo o método de fibra detergente ácido (FDA), conforme descrito em Makkar (2001).

As porcentagens de fibra em detergente neutro (FDN) e de fibra em detergente ácido (FDA) foram determinadas por análise não seqüencial, sendo método descrito por VAN SOEST et al. (1991). Na técnica de FDN utilizaram-se $0,5 \mathrm{~g}$ de sulfito de sódio e $200 \mu \mathrm{L}$ de alfa amilase. As determinações bromatológicas foram realizadas no Laboratório de Bromatologia da Faculdade de Zootecnia e Engenharia de alimentos/USP. Para todas as análises foram realizadas duplicatas das amostras obtidas em cada parcela. 


\subsubsection{Análises Estatísticas}

Foram realizadas análises descritivas dos macro e micronutrientes presentes nas folhas, no solo (de $0-20 \mathrm{~cm}$ e de $20-40 \mathrm{~cm}$ ), para as variáveis bromatológicas, relacionadas à produção de grãos e do Nitrogênio Volatilizado Total Acumulado (NVTac), visando estabelecer o padrão característico observados nos tratamentos avaliados, bem como na verificação das pressuposições comumente utilizadas em análises de dados experimentais. Estas análises descritivas foram realizadas por meio de procedimento PROC MEANS do programa Statistical Analysis System, versão 9.1.3 (SAS, 1996).

Para avaliação dos macro e micronutrientes presentes nas folhas, no solo (de 0-20 cm e de 20-40 cm), variáveis bromatológicas, relacionadas à produção de grãos e NVTac, segundo os tratamentos avaliados, utilizou-se o procedimento PROC GLM do programa citado anteriormente. Foram considerados os efeitos fixos de blocos e tratamentos. Nestas análises adotouse o seguinte modelo estatístico:

$$
y_{i j}=\mu+T_{i}+B_{j} e_{i j}
$$

em que,

$\mathrm{y}_{\mathrm{ij}}=$ é o valor para a variável relacionada ao macro ou micronutrientes presentes nas folhas, no solo (de $0-20 \mathrm{~cm}$ e de $20-40 \mathrm{~cm}$ ), para as variáveis bromatológicas, relacionadas à produção de grãos observado e Nitrogênio Volatilizado Total Acumulado (NVTac) no bloco i e no tratamento i;

$\mu=$ constante inerente a todas observações;

$\mathrm{T}_{\mathrm{i}}=$ efeito do i-ésimo tratamento, sendo $\mathrm{i}=[1$ (testemunha+gesso $(-\mathrm{N}+\mathrm{S}) ; 2$ (testemunha absoluta (-N-S); 3 (Uréia - 45\% N); 4 (Uréia + Gesso 14\%S); 5 (Uréia + Sulfato de Amônio - 21\%N/24\%S - (33:00:00+12\%S)*); 6 (Nitrato de Amônio - NA - 30\%N); 7 (Nitrato de Amônio - NA - 30\%N + Gesso); 8 (NA + Sulfato de Amônio - 21\%N/24\%S - (27,8:00:00+6\%S)**); 9 (SAM) e 10 (FASN 26\%N/14\%S); 
$B_{j}=$ efeito do j-ésimo bloco, sendo j = 1 (bloco 2), 2(bloco 2), 3 (bloco 3) e 4 (bloco 4);

$\mathrm{e}_{\mathrm{ijkl}}=$ efeito aleatório residual associado a variável relacionada ao macro ou micronutrientes presentes nas folhas, no solo (de $0-20 \mathrm{~cm}$ e de $20-$ $40 \mathrm{~cm}$ ), para as variáveis bromatológicas, relacionadas à produção de grãos e Nitrogênio Volatilizado Total Acumulado (NVTac) observado no bloco j e no tratamento i.

Nas análises acima descritas, em caso de resultados significativos para o Teste F da análise de variância (ANOVA), utilizou-se o Teste de Tukey como Procedimento para Comparações Múltiplas (PPMC).

Para avaliação das informações associadas ao Nitrogênio Volatilizado Total (NTV) e para Taxa Média de Nitrogênio Volatilizado (TMNVt) e segundo os tratamentos avaliados, utilizou-se o procedimento PROC GLM do programa citado anteriormente. Foram considerados os efeitos fixos de blocos, tratamentos e dias de avaliação. Nestas análises adotou-se o seguinte modelo estatístico:

$$
y_{i j k}=\mu+T_{i}+D_{j}+T D_{i j}+B_{k} e_{i j k}
$$

em que,

$\mathrm{y}_{\mathrm{ij}}$ = é o valor para a variável NTV ou TMNVt observado no bloco $\underline{\mathrm{k}}$, dia j e no tratamento i;

$\mu=$ constante inerente a todas observações;

$\mathrm{T}_{\mathrm{i}}=$ efeito do i-ésimo tratamento, sendo $\mathrm{i}=1$ (testemunha+gesso $(-\mathrm{N}+\mathrm{S}) ; 2$ (testemunha absoluta (-N-S); 3 (Uréia - 45\% N); 4 (Uréia + Gesso 14\%S); 5 (Uréia + Sulfato de Amônio - 21\%N/24\%S - (33:00:00+12\%S)*); 6 (Nitrato de Amônio - NA - 30\%N); 7 (Nitrato de Amônio - NA - 30\%N + Gesso); 8 (NA + Sulfato de Amônio - 21\%N/24\%S - (27,8:00:00+6\%S)^); 9 (SAM) e 10 (FASN - 26\%N/14\%S);

$D_{j}=$ efeito do j-ésimo dia da avaliação, sendo j = 1 (dia 0-20/12/2007), 2(dia 222/12/2006), 3 (dia 4-24/12/2006), 4 (dia 6-26/12/2006), 5 (dia 10- 
30/12/2006), 6 (dia 13-3/1/2007), 7 (dia 16-6/1/2007) e 8 (dia 2010/01/2007);

$T D_{i j}=$ efeito da interação do tratamento $\underline{i}$ com o dia j;

$B_{k}=$ efeito do $k$-ésimo bloco, sendo $k=1$ (bloco 2), 2(bloco 2), 3(bloco 3) e 4 (bloco 4);

$\mathrm{e}_{\mathrm{ijk}}=$ efeito aleatório residual associado a variável NTV ou TMNVt observado no bloco $\underline{\mathrm{k}}$, dia $\mathrm{j}$ e no tratamento $\underline{\mathrm{i}}$.

Para este modelo, uma vez que foram verificados resultados significativos $(P<0,05)$ para Interação dupla Tratamentos versus Dias de Avaliação, procederam-se o desdobramento visando estudar os efeitos dos dias dentro de cada Tratamento avaliados. Neste caso, como o efeito de dias de avaliação foi considerado um fator não aleatório quantitativo, foram utilizadas análises de regressão visando identificar o(s) melhor (es) modelo(s) que relacionam o comportamento dos valores observados de NTV ou TMNVt para cada tratamento avaliado. 


\section{RESULTADOS E DISCUSSÃO}

\subsection{Perda acumulada de $\mathrm{N}-\mathrm{NH}_{3}$ das fontes nitrogenadas}

Na Figura 20 verifica-se as perdas de $\mathrm{N}^{-\mathrm{NH}_{3}}$ ocorridas após aplicação do fertilizante nitrogenado. Nos tratamentos com uréia as perdas máximas ocorreram até os seis primeiros dias após aplicação do fertilizante, como verificados Alves et al., (2006), Costa et al. (2003), Lara Cabezas \& Trivellin (1990), mostrando que, a volatilização de $\mathrm{NH}_{3}$ é rápida quando as condições de chuva, temperatura, umidade são favoráveis e o processo inicia-se logo após a aplicação da uréia pela rápida hidrólise no solo (RODRIGES \& KIEHL, 1986; SENGIK \& KIEHL, 1995a; LARA CABEZAS et al. 1997a; COSTA et al, 2003). Gava (1999) encontrou, em condições de campo perdas nos 11 primeiros dias após aplicação dos fertilizantes em área total com uréia sobre a palha.

Ao final do período de avaliação, observou-se que a aplicação de T3 (Uréia), T4 (Uréia + Gesso) e T5 (Uréia + Sulfato de amônio) não diferiram entre si e apresentaram maiores perdas acumuladas de $\mathrm{N}-\mathrm{NH}_{3}(13,5,13,0$ e 10,8\% respectivamente). Os valores de volatilização obtidos em T3(Uréia) deveram-se à susceptibilidade de perda que a fonte apresenta, aos efeitos da urease, tanto da palha como do solo, e à baixa capacidade de retenção de amônia da palha (Freney et al., 1992). Quando a uréia é aplicada na superfície da palha, pode levar a perdas de 30 a 94\% do nitrogênio por volatilização de N$\mathrm{NH}_{3}$ (Deanmead et al., 1990 ; Wood , 1991; Freney et al., 1992; Oliveira et al., 1997; Cantarella et al., 1999).

No tratamento T5, a aplicação da mistura entre uréia e sulfato de amônio sobre a palha, e causou deslocamento do equilíbrio químico entre amônia e o íon amônio $\left(\mathrm{NH}_{3}+\mathrm{NH}_{4}^{+} \Rightarrow \mathrm{H}_{2} \mathrm{O}+\mathrm{OH}^{-}\right)$para a esquerda, favorecendo a volatilização de $\mathrm{N}-\mathrm{NH}_{3}$. Vitti et al. (2001) realizaram experimento em laboratório e observaram que a mistura de $50 \%$ de uréia com 50\% de sulfato de amônio aplicada ao solo, resultou em menor volatilização de amônia em relação às misturas com menores quantidades de sulfato de amônio e à aplicação 
exclusiva de uréia. Os mesmos autores atribuíram a menor perda ao efeito de controle a elevação de $\mathrm{pH}$ e à redução na quantidade de $\mathrm{N}$-amídico proporcionados pela mistura. A quantidade de $\mathrm{N}$ aplicada na fonte permitiu estimar o fornecimento de $\mathrm{N}$ pelo solo e pela atmosfera.

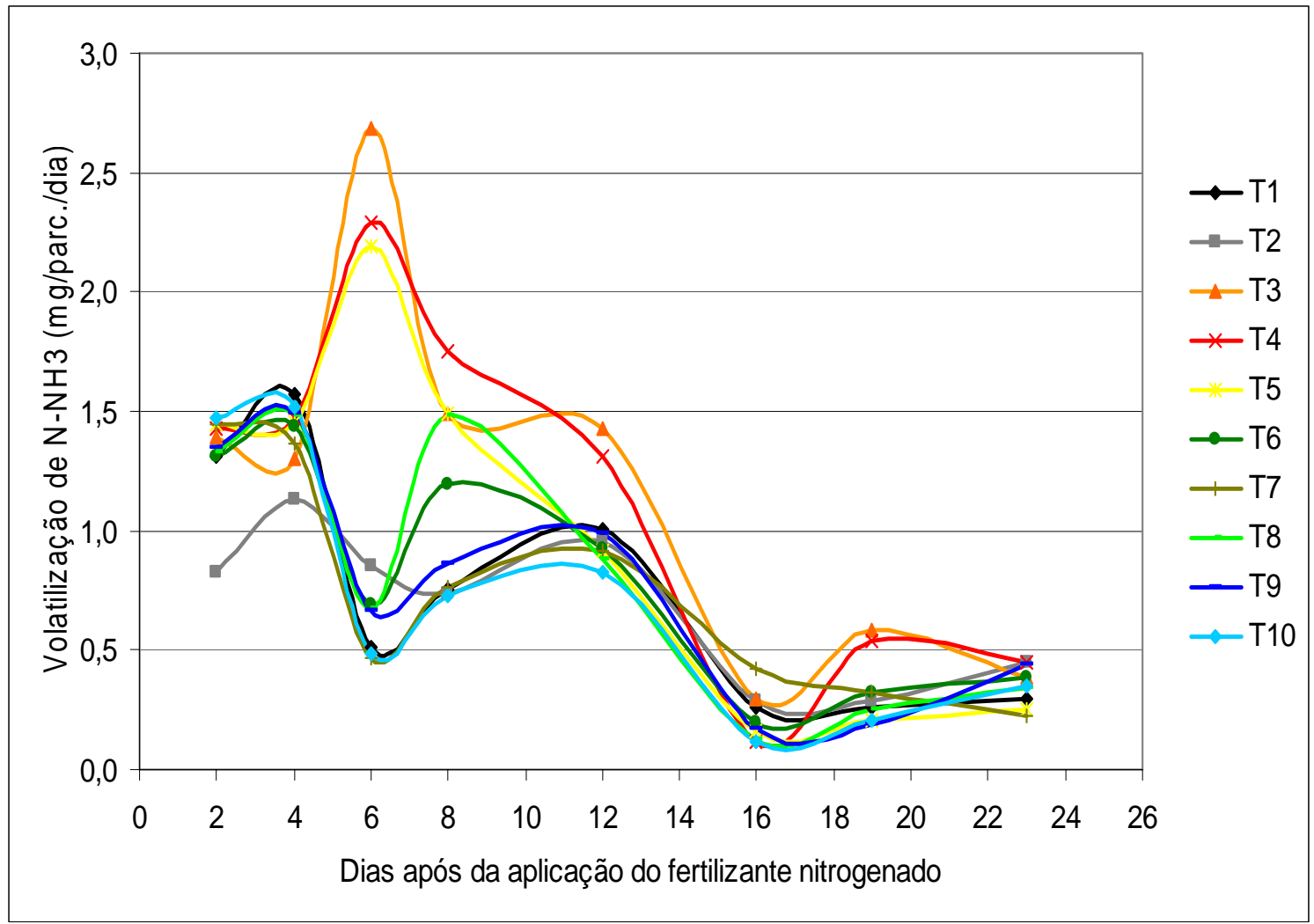

Figura 20. Estimativas das perdas de $\mathrm{N}-\mathrm{NH}_{3}$ volatilizado (mg/parc/dia) proveniente de fontes nitrogenadas.

Não houve diferença significativa entre os tratamentos em estudo Figura 21. A recuperação aparente de $N$ variou $(P<.0,0001)$ com a fonte aplicada de $\mathrm{N}$, no período de amostragem. Os dados da Figura 21 mostram elevado potencial de extração de $N$ nos grãos pelas plantas, já que parte do nitrogênio, não determinado, pode ser imobilizado nas raízes e pela biomassa microbiana do solo. 


\section{Recuperação aparente}

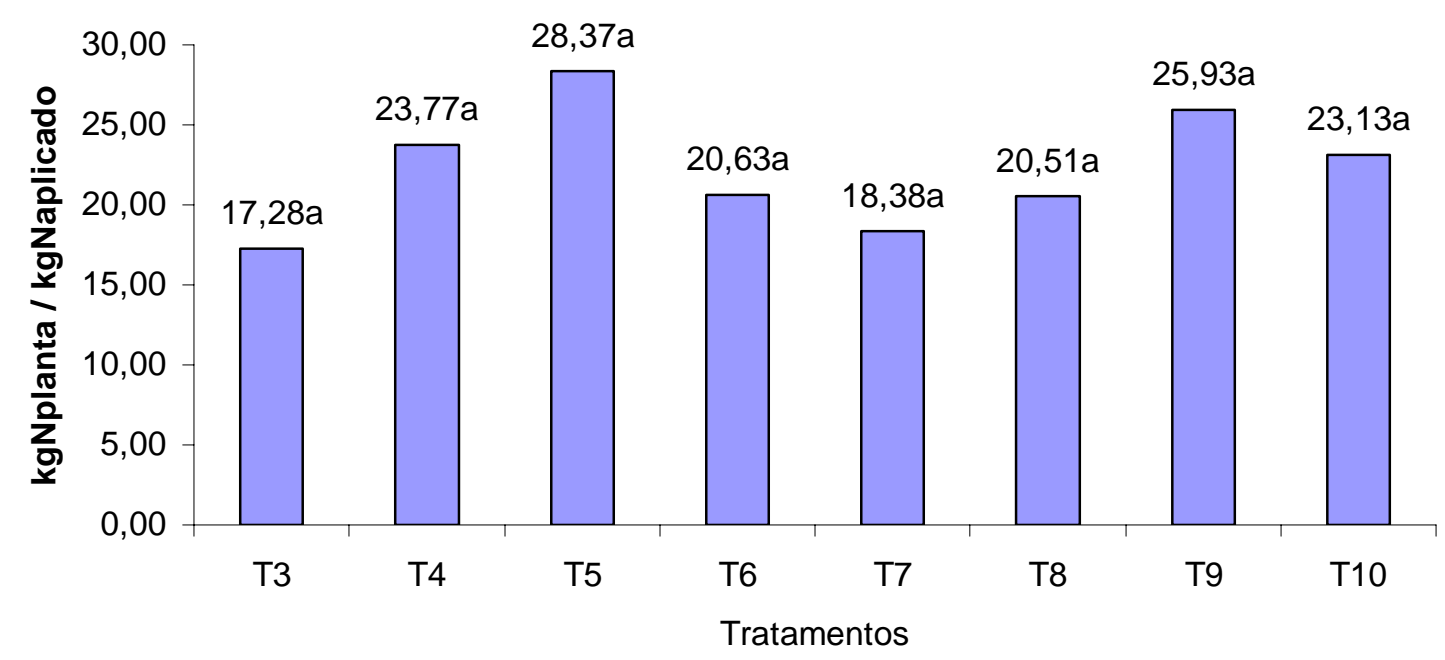

Figura 21. Recuperação aparente de N no grão de milho.

No presente trabalho obtiveram-se baixos valores de perdas de amônia por volatilização que são explicados, em parte, pela variação nas condições climáticas do período experimental (Anexo 1 e 2). O mesmo comportamento foi observado por Primavesi (2001), onde as perdas de $\mathrm{N}$ nos seis primeiros dias após aplicação da uréia dependeram das condições atmosféricas e da dose de $\mathrm{N}$ aplicada, especialmente do total de chuvas ocorrentes nos dois dias anteriores à aplicação do adubo, que determinaram a umidade do solo, e das chuvas ocorrentes no inicio do período experimental. Verificou-se também tendência de efeitos da temperatura mínima, da temperatura máxima e da umidade relativa do ar.

Ficou confirmado que as maiores perdas de $\mathrm{N}$ ocorrem principalmente nos seis primeiros dias após a aplicação de uréia, sugerindo que ocorre rápida hidrolise. Após os seis dias, as perdas diminuem, provavelmente, em consequêencia da queda do $\mathrm{pH}$ do solo associada ao consumo de $\mathrm{OH}^{-}$durante a volatilização e à nitrificação do amônio (Whitehead, 1995). Também baixos valores de amônia por volatilização pode-se explicar porque durante a condução do presente experimento as chuvas enterraram a uréia como se verifica no anexo 1 e 2 . O total de chuva dois e quatro dias antes da aplicação do N (16/12/2006) foi de 29,8 mm e após a aplicação do $\mathrm{N}$ foi de 32,2 mm. 
As diferenças na taxa de nitrificação do sulfato de amônio e da uréia ocorrem devido as diferenças de $\mathrm{pH}$ das soluções fertilizantes. $\mathrm{O} \mathrm{pH}$ ótimo para a nitrificação está entre 7,9-9; o pH da solução da uréia situa-se ao redor do 9 e da solução do sulfato de amônio ao redor de 5,1 assim o $\mathrm{NH}_{4}{ }^{+}$da uréia nitrificase mais rapidamente que o $\mathrm{NH}_{4}{ }^{+}$da solução do sulfato de amônio perdendo-se em maior quantidade. A menor perda total por volatilização de amônia do sulfato de amônio e do nitrato de amônio em relação ao uréia, ocorre pela substituição do N-amídico pelo N-amoniacal e N-nítrico.

As perdas ocorridas em Nitrato + Gesso também foram consideradas baixas em relação às demais. Tal observação é resultado da característica qualitativa do resíduo utilizado que, além de nitrogênio e enxofre, possui cátions $(\mathrm{K}, \mathrm{Ca}, \mathrm{Mg})$ que pode contribuir para reduzir o potencial de volatilização (Fenn \& Myamoto, 1981; Fenn \& Richards, 1984; Sengik \& Kiehl, 1995).

Misturas de sais com uréia também poderiam ser utilizadas para reduzir as perdas de $\mathrm{N}-\mathrm{NH}_{3}$ por volatilização, mas as evidências sobre a efetividade dessa prática, no aumento da eficiência de uso do $\mathrm{N}$ da uréia, não são consistentes (Rappaport \& Axley, 1984; Oliveira, 2001; Vitti et al., 2001). Obteve-se resultado semelhante no presente trabalho.

Em razão do elevado risco de perda do $\mathrm{N}$-uréia, aplicado nessas condições, recomenda-se que estudos futuros considerem as seguintes alternativas para controlar a volatilização de $\mathrm{N}^{-\mathrm{NH}_{3}}$ e, conseqüentemente aumentar a eficiência de uso do $\mathrm{N}$ - fertilizante pela cultura de milho: 1) as chuvas depois da adubação favorece a desnitrificação; 2) o uso de misturas de sais com uréia para determinar se a manipulação relação N:S do fertilizante, por exemplo, é realmente uma maneira eficaz de controlar as perdas de $\mathrm{N}^{-\mathrm{NH}_{3}}{ }^{-}$ em ecossistemas agrícolas; 3) o uso de outras fontes de fertilizante nitrogenado menos propensas às perdas de amônia por volatilização, como os sais amoniacais. A utilização de outros fertilizantes nitrogenados, que não a uréia, parece ser no curto prazo, a alternativa mais viável tecnicamente. (Martha Jr., 1999; Primavesi et al., 2001). Adicionalmente, tem sido demonstrado que parte do $\mathrm{N}$ volatilizado pode ser absorvido pelas cobertas vegetais, o que contribuiria para minimizar as perdas de $\mathrm{N}-\mathrm{NH}_{3}$ do sistema solo-planta. 
Na Tabela 5 e Figura 22, são apresentadas as equações de regressão dos diferentes tratamentos em função dos dias de avaliação referentes as perdas diárias da taxa nitrogênio médio volatilizado total (TMNVt). Verifica-se que, a medida que os dias de avaliação foram aumentando, as perdas de TMNVt diminuíram, acompanhando a tendência observada para nitrogênio voltatilizado total (NVT). As volatilizações observadas para TMNVt comportaram-se de forma lineares, quadrática ou cúbicas para os tratamentos avaliados (como observado nos padrões de respostas da (Figura 22). As perdas relativas tenderam a diminuir linearmente (tratamentos T1, T2, T6, T7, T8 e T9), ou mesmo aumentarem com níveis crescentes de aplicação do fertilizante nitrogenado, seguidos de posterior queda e retornando a uma fase crescente, porém de menor intensidade (tratamentos T3, T4 e T5), ou ainda decrescendo de forma bem acentuada no primeiros dias de avaliação seguida de reduções mais suaves com o aumento dos dias (T10). Portanto, os tratamentos T1, T2, T6, T7, T8 e T9 apresentaram respostas com efeitos lineares decrescentes, enquanto que, para os tratamentos T3, T4 e T5, foram observadas respostas com efeitos cúbicos. Para o tratamento T10, foi evidenciado padrão de resposta quadrático.

Para o nitrogênio total médio volatilizado, notou-se comportamento semelhante ao do nitrogênio volatilizado total (NVT), ou seja, os tratamentos com uréia tiveram picos de perdas de ao redor de 6 dias, enquanto que os demais tratamentos com outras fontes de $\mathrm{N}$ apresentaram redução contínua linear, com exceção do FASN cuja redução foi quadrática. 
Tabela 5. Equações da taxa média diária de nitrogênio volatilizado total (TMNVt)

\begin{tabular}{|c|c|c|}
\hline TRAT & Equações de predição para TMNVt & $\mathbf{R}^{2}$ \\
\hline 1 & $Y=1.2476-0.0563 X$ & 52,62 \\
\hline 2 & $Y=0.9968-0.0343 X$ & 38,25 \\
\hline 3 & $Y=1.2922+0.3392 X-0.0496 X 2+0.0015 X^{3}$ & 51,60 \\
\hline 4 & $Y=1.3335+0.3334 X-0.0516 X 2+0.0016 X^{3}$ & 72,77 \\
\hline 5 & $Y=1.3964+0.2549 X-0.0450 X 2+0.0015 X^{3}$ & 87,25 \\
\hline 6 & $Y=1.3125-0.0567 X$ & 62,31 \\
\hline 7 & $Y=1.2255-0.0545 X$ & 48,27 \\
\hline 8 & $Y=1.3896-0.0641 X$ & 61,15 \\
\hline 9 & $Y=1.2747-0.0568 X$ & 54,71 \\
\hline 10 & $Y=1.4385-0.1538 X+0.0048 X^{2}$ & 61,34 \\
\hline
\end{tabular}

$\mathrm{Na}$ Tabela 6 encontram-se os resultados do nitrogênio volatilizado total acumulado (NVTac) no período avaliado e as perdaas de $\mathrm{N}(\%)$ volatilizado pelas fontes estudadas.

\begin{tabular}{clccc}
\hline Tratamentos & \multicolumn{1}{c}{ Especificação } & Nvtac & Kg ha & ef. (\%) \\
\hline $\mathbf{1}$ & Testemunha + Gesso(-N+S) & 15,36 & 8,69 & 91,3 \\
$\mathbf{2}$ & Testemunha absoluta(-N-S) & 14,76 & 8,35 & 91,6 \\
$\mathbf{3}$ & Uréia- 45\%N & 23,94 & 13,55 & 86,5 \\
$\mathbf{4}$ & Uréia + Gesso- 14\%S & 23,01 & 13,02 & 87 \\
$\mathbf{5}$ & Uréia + Sulfato de Amônio - 21\%N24\%S-(33:00:+12\%S)* & 19,11 & 10,82 & 89,2 \\
$\mathbf{6}$ & Nitrato de Amônio NA - 30\%N & 16,28 & 9,21 & 90,8 \\
$\mathbf{7}$ & Nitrato de Amônio- NA + GeSso & 15,33 & 8,67 & 91,3 \\
$\mathbf{8}$ & NA + Sulfato de Amânio- 21\%N/24\%S-(27,8:00:00+6\%S)** & 16,08 & 9,10 & 90,9 \\
$\mathbf{9}$ & SAM- 21\%N14\%S & 15,71 & 8,89 & 91,1 \\
$\mathbf{1 0}$ & FASN-26\%N14\%S & 14,24 & 8,06 & 91,9 \\
\hline
\end{tabular}



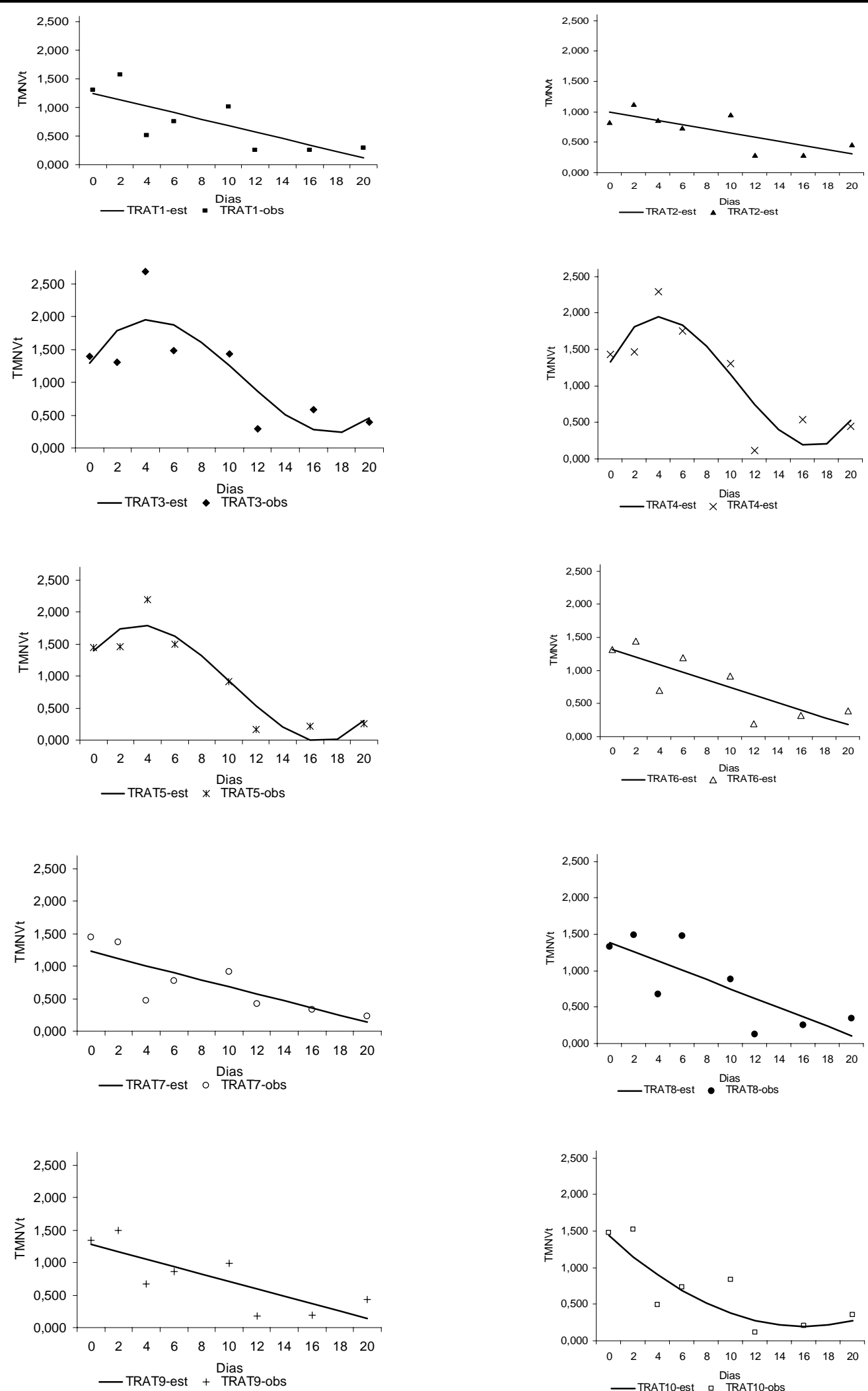

Figura 22. Efeito dos dias de monitoramento sobre os tratamentos avaliados para o taxa média de nitrogênio volatilizado total (TMNVt). 
Esses resultados evidenciaram padrão diferenciado de perdas de $\mathrm{N}$ $\mathrm{NH}_{3}$, ou seja, as fontes que contém uréia levam a um padrão de perda cúbica, com um pico de perda ao redor dos 6 dias, após aplicação dos fertilizantes, enquanto que as demais fontes tratadas (sulfato de amônio, nitrato de amônio e misturas) implicaram um comportamento linear decrescente, com inclinação similares, com exceção do tratamento T10 - FASN, cuja as perdas apresentaram comportamento quadrático na unidade de tempo.

O elevado potencial de hidrólise da uréia em solos sob plantio direto, a elevação do pH no local de hidrólise da uréia e dos elevados níveis de conteúdo de água no solo (Ernst \& Massey, 1960; Black et al., 1985; Hargrove, 1988). Como fatores de clima, destacam-se a elevada temperatura e falta de chuva no dia subseqüente à aplicação do fertilizante (Black et al., 1987; Bouwmeester et al., 1985; Hargrove, 1988). Os altos índices pluviométricos observados no trabalho reforçam a relação entre as perdas de $\mathrm{N}-\mathrm{NH}_{3}$ e os mesmos, de forma a levar as menores perdas de $\mathrm{N}-\mathrm{NH}_{3}$ determinadas.

Cantarella et al. (1999) observaram que a ocorrência de chuvas reduziu a volatilização e concluíram que as taxas de perdas eram mais acentuadas, quando as chuvas não eram suficientes para incorporar a uréia ao solo. Contudo, como a uréia é o fertilizante nitrogenado mais barato no mercado, cabe ao produtor/técnico decidir se vale a pena pagar mais para minimizar os riscos de perda de amônia por volatilização.

Destaca-se que as funções de regressão obtidas para variáveis TMNVt são válidas somente para o período avaliado, ou seja de 0 a 20 dias. Qualquer tentativa de predição dos efeitos dos tratamentos em períodos superiores aos avaliados estão sujeitos a erros pelo fato de que as funções são válidas para o período em estudo. 


\subsection{Avaliação do estado nutricional do milho}

\subsubsection{Teores foliares de macronutrientes}

$\mathrm{Na}$ Tabela 8 verifica-se que houve diferenças significativas para teores foliares de nitrogênio $(N)$, os quais foram menores em T1 (Testemunha +Gesso), T2 (Testemunha absoluta) e maiores em T4 (Uréia + Gesso), T7 (NA + Gesso) e T8 (NA + Sulfato de Amônio) que não diferiram entre si. T1 (Testemunha +Gesso) foi inferior aos tratamentos T4 (Uréia + Gesso) a T10 (FASN), e T2 (Testemunha absoluta) e T3 (Uréia) apresentaram teores foliares de $\mathrm{N}$ intermediários aos demais tratamentos. Em todos os tratamentos em que se observou as maiores perdas de $\mathrm{N}-\mathrm{NH}_{3}$ por volatilização, o teor foliar de $\mathrm{N}$ foi inversamente proporcional às perdas ocorridas. Analisando o teor foliar de $\mathrm{N}$ do T5 (Uréia + sulfato de amônio) supõem-se que devido a mistura da uréia com sulfato de amônio esse tratamento apresentou taxa de volatilização semelhante àquelas encontradas em T4 (Uréia + Gesso) e T9 (SAM). Esses resultados mostram que o teor de $\mathrm{N}$ nas folhas sofrem influência das perdas por volatilização do $\mathrm{N}$ aplicado.

O tratamento T10 (FASN) apresentou bom comportamento, por ser uma mistura de nitrato e sulfato de amônio que são menos propensos as perdas por volatilização, obteve baixa perda de $\mathrm{N}-\mathrm{NH}_{3}$ acumulada, com ótimos teores foliares de $\mathrm{N}$, pois é menos propenso a volatilização em relação à uréia.

Não houve diferenças significativas entre os teores foliares de Fósforo (P). Orlando Filho et al. (1998) verificaram que valores de Fósforo no solo acompanharam aumentos da matéria orgânica, de modo que maiores teores foliares poderiam estar relacionados com maiores teores de M.O. no solo, neste trabalho os tratamentos não apresentaram diferença entre os teores de M.O. Os teores foliares de $\mathrm{K}, \mathrm{Ca}, \mathrm{Mg}$ e $\mathrm{S}$ não apresentaram diferenças significativas. Os resultados de teores foliares de macronutrientes obtidos neste trabalho (Tabela 8), quando comparados com os considerados adequados (Tabela 7), para a cultura do milho, verifica-se que os teores de $\mathrm{N}, \mathrm{P}, \mathrm{K}, \mathrm{Ca}$, Mg, e S são superiores. 
Os resultados dos teores foliares de macronutrientes dos encontrados neste trabalho estão dentro da faixa, considerados adequados para culturas de milho, citados por BÜLL (1993).

Tabela 7. Teores foliares de nutrientes considerados adequados para a cultura do milho.

\begin{tabular}{cccc} 
Macronutrientes & Teor $(\mathbf{g} / \mathbf{k g})$ & Micronutrientes & Teor $\mathbf{( m g} / \mathbf{k g})$ \\
\hline Nitrogênio & $2,75-3,25$ & Boro & $15-20$ \\
Fósforo & $0,19-0,35$ & Cobre & $6-20$ \\
Potássio & $1,75-2,97$ & Ferro & $50-250$ \\
Cálcio & $0,23-0,40$ & Manganês & $42-150$ \\
Magnésio & $0,15-0,40$ & Molibdênio & $0,15-0,20$ \\
& & & $15-20$ \\
Enxofre & $0,15-0,21$ & Zinco & \\
\hline
\end{tabular}

Fonte: Bull (1993). 
Tabela 8. Teores foliares de macronutrientes no milho.

\begin{tabular}{ccccccc}
\hline Trat. & $\mathbf{N}$ & $\mathbf{P}$ & $\mathbf{K}$ & $\mathbf{C a}$ & $\mathbf{M g}$ & $\mathbf{S}$ \\
\cline { 2 - 7 } & \multicolumn{5}{c}{$\mathbf{g} / \mathbf{K g}^{-1}$} \\
T1 & $18,79 \mathrm{~b}$ & $1,68 \mathrm{a}$ & $27,05 \mathrm{a}$ & $4,14 \mathrm{a}$ & $2,56 \mathrm{a}$ & $1,04 \mathrm{a}$ \\
T2 & $20,60 \mathrm{ab}$ & $1,70 \mathrm{a}$ & $26,70 \mathrm{a}$ & $3,91 \mathrm{a}$ & $2,52 \mathrm{a}$ & $1,03 \mathrm{a}$ \\
T3 & $21,31 \mathrm{ab}$ & $1,85 \mathrm{a}$ & $27,75 \mathrm{a}$ & $3,32 \mathrm{a}$ & $1,90 \mathrm{a}$ & $1,09 \mathrm{a}$ \\
T4 & $22,95 \mathrm{a}$ & $1,90 \mathrm{a}$ & $28,77 \mathrm{a}$ & $3,42 \mathrm{a}$ & $1,79 \mathrm{a}$ & $1,06 \mathrm{a}$ \\
T5 & $22,67 \mathrm{a}$ & $1,97 \mathrm{a}$ & $28,49 \mathrm{a}$ & $3,61 \mathrm{a}$ & $1,70 \mathrm{a}$ & $1,13 \mathrm{a}$ \\
T6 & $22,05 \mathrm{a}$ & $1,82 \mathrm{a}$ & $28,77 \mathrm{a}$ & $3,23 \mathrm{a}$ & $1,58 \mathrm{a}$ & $1,14 \mathrm{a}$ \\
T7 & $23,38 \mathrm{a}$ & $1,77 \mathrm{a}$ & $28,00 \mathrm{a}$ & $3,37 \mathrm{a}$ & $1,96 \mathrm{a}$ & $1,12 \mathrm{a}$ \\
T8 & $23,68 \mathrm{a}$ & $1,72 \mathrm{a}$ & $27,94 \mathrm{a}$ & $3,11 \mathrm{a}$ & $1,61 \mathrm{a}$ & $1,14 \mathrm{a}$ \\
T9 & $22,74 \mathrm{a}$ & $1,88 \mathrm{a}$ & $27,42 \mathrm{a}$ & $3,05 \mathrm{a}$ & $1,57 \mathrm{a}$ & $1,11 \mathrm{a}$ \\
T10 & $23,38 \mathrm{a}$ & $1,51 \mathrm{a}$ & $27,23 \mathrm{a}$ & $3,42 \mathrm{a}$ & $1,68 \mathrm{a}$ & $1,11 \mathrm{a}$ \\
\hline Média & 22,16 & 1,78 & 27,81 & 3,46 & 1,89 & 1,10 \\
Valor F (\%) & $0,0003^{* *}$ & $0,13 \mathrm{~ns}$ & $0,11 \mathrm{~ns}$ & $0,28 \mathrm{~ns}$ & $0,03 \mathrm{~ns}$ & $0,02 \mathrm{~ns}$ \\
CV (\%) & 5,91 & 11,33 & 3,86 & 17,37 & 24,56 & 4,45 \\
DMS & 3,18 & 0,49 & 2,61 & 1,46 & 1,13 & 0,12 \\
\hline
\end{tabular}

Legenda Tabela - T1: Testemunha +Gesso (-N+S), T2: Testemunha absoluta (N-S), T3: Uréia - 45\% N, T4: Uréia + Gesso - 14\%S, T5: Uréia + sulfato de amônio - 21\%N/24\%S-(33:00:00+12\%S) T7: Nitrato de amônio - NA - 30\%N + gesso, T8: NA + Sulfato de Amônio $21 \% \mathrm{~N} / 24 \% \mathrm{~S}-(27,8: 00: 00+6 \% \mathrm{~S})^{\star \star}$, T9: SAM, T10: FASN - 26\%N/14\%S. Médias contidas nas colunas seguidas de mesma letra não diferem entre si pelo teste $\mathrm{F} .{ }^{*}$ e ${ }^{* *}$ nível de significância de 5 e $1 \%$ respectivamente de probabilidade. ns: não significativo.

\subsubsection{Teores foliares de micronutrientes}

Somente houve diferença entre tratamentos para teores de cobre $(\mathrm{Cu})$. $\mathrm{O}$ tratamento $\mathrm{T5}$ apresentou maior teor de $\mathrm{Cu}$ nas folhas, em relação a T1, enquanto que os demais apresentaram teores intermediários. O cobre pode estar na solução do solo (disponível para as plantas) ou pode estar na matéria orgânica. Este resultado encontrado no T5 poderia ser resultado de maior disponibilidade no solo em função de maior teor de matéria orgânica, porém a matéria orgânica no solo não foi diferente entre os tratamentos. Os teores foliares de Fe, Mn e Zn não apresentaram diferenças significativas.

Em relação aos micronutrientes comparados com teores foliares considerados adequados para culturas produtivas de milho (Tabela 7), 
verificou-se que apenas os teores de cobre (Cu 6-20) estão a cima de valores considerados adequados, e os demais nutrientes apresentam teores considerados satisfatórios.

Tabela 9. Teores foliares de micronutrientes no milho

\begin{tabular}{ccccc}
\hline Trat. & $\mathbf{C u}$ & $\mathbf{F e}$ & $\mathbf{M n}$ & $\mathbf{Z n}$ \\
\cline { 2 - 5 } & \multicolumn{4}{c}{$\mathbf{~ m g / K g}$} \\
\hline T1 & $22,08 \mathrm{~b}$ & $89,58 \mathrm{a}$ & $32,56 \mathrm{a}$ & $29,61 \mathrm{a}$ \\
T2 & $22,81 \mathrm{ab}$ & $98,71 \mathrm{a}$ & $34,34 \mathrm{a}$ & $25,25 \mathrm{a}$ \\
T3 & $25,18 \mathrm{ab}$ & $106,02 \mathrm{a}$ & $35,07 \mathrm{a}$ & $27,85 \mathrm{a}$ \\
T4 & $25,36 \mathrm{ab}$ & $103,27 \mathrm{a}$ & $34,95 \mathrm{a}$ & $27,76 \mathrm{a}$ \\
T5 & $26,16 \mathrm{a}$ & $114,13 \mathrm{a}$ & $34,93 \mathrm{a}$ & $31,50 \mathrm{a}$ \\
T6 & $23,99 \mathrm{ab}$ & $104,05 \mathrm{a}$ & $37,64 \mathrm{a}$ & $29,08 \mathrm{a}$ \\
T7 & $24,61 \mathrm{ab}$ & $131,77 \mathrm{a}$ & $38,23 \mathrm{a}$ & $28,87 \mathrm{a}$ \\
T8 & $25,36 \mathrm{ab}$ & $113,16 \mathrm{a}$ & $38,68 \mathrm{a}$ & $28,84 \mathrm{a}$ \\
T9 & $25,65 \mathrm{ab}$ & $106,89 \mathrm{a}$ & $38,21 \mathrm{a}$ & $28,86 \mathrm{a}$ \\
T10 & $23,88 \mathrm{ab}$ & $101,09 \mathrm{a}$ & $38,45 \mathrm{a}$ & $27,60 \mathrm{a}$ \\
\hline Média & 24,51 & 106,866 & 36,31 & 28,52 \\
Valor F (\%) & $0,01^{*}$ & $0,41 \mathrm{~ns}$ & $0,18 \mathrm{~ns}$ & $0,38 \mathrm{~ns}$ \\
CV (\%) & 6,25 & 20,19 & 9,58 & 10,62 \\
DMS & 3,73 & 52,48 & 8,46 & 7,36 \\
\hline
\end{tabular}

Legenda - T1: Testemunha +Gesso (-N+S), T2: Testemunha absoluta (-N-S), T3: Uréia - 45\% N, T4: Uréia + Gesso - 14\%S, T5: Uréia + sulfato de amônio 21\%N/24\%S-(33:00:00+12\%S), T6: Nitrato de amônio - NA - 30\%N, T7: Nitrato de amônio - NA - 30\%N + gesso, T8: NA + Sulfato de amônio $21 \% \mathrm{~N} / 24 \% \mathrm{~S}-(27,8: 00: 00+6 \% \mathrm{~S})^{\star \star}$, T9: SAM, T10:FASN - 26\%N/14\%S. Médias contidas nas colunas seguidas de mesma letra não diferem entre si pelo teste $\mathrm{F} .{ }^{*} \mathrm{e}{ }^{* *}$ nível de significância de 5 e $1 \%$ respectivamente de probabilidade. ns: não significativo. 


\subsection{Avaliação da produtividade e dos atributos qualitativos do milho}

$\mathrm{Na}$ Tabela 10 verifica-se que houve diferença significativa da produtividade corrigida. Verificou-se que a produção de grãos de milho foi menor em T1 e T2, devido a ausência de adubação nitrogenada.

A maior produção de grãos de milho por hectare observada no experimento foi de $7128 \mathrm{t} \mathrm{ha}^{-1}$, evidentemente o bom desempenho da fonte sulfato de amônio, implicando bons teores foliares de $\mathrm{N}$ e conseqüentemente potencializando altas produtividades. Gava (1999) menciona que a diminuição da produtividade varia com o tempo de implantação do sistema de colheita de milho, com as condições climáticas e de manejo (compactação do solo, sanidade das plantas, variedade utilizada). A eficiência de $\mathrm{N}$ no grão de milho, a umidade e o número de plantas não diferiram significativamente. No tratamento T1 e T2 não se calculou a eficiência do uso de $\mathrm{N}$ no grão do milho porque não receberam aplicação de $\mathrm{N}$.

Houve resposta positiva para aplicação de Nitrogênio no milho, independentemente da fonte nitrogenada, porém com tendência de melhores resultados nos tratamentos T5, T9 e T10. O tratamento T10 (FASN) apresenta desempenhos positivos nas perdas por volatilização de $\mathrm{N}-\mathrm{NH}_{3}$ e produtividade na cultura do milho, o que expressa seu grande potencial de uso no Brasil. Sua composição é determinada pela fusão do sulfato de amônio e nitrato de amônio, que são sais amoniacais utilizados como fontes de Nitrogênio. 
Tabela 10. Umidade do grão (UG\%), número de plantas (Nu.plantas), produtividade corrigida (Prod._cor. $\mathrm{Kg} \mathrm{ha}^{-1}$ ) e eficiência no grão de milho (Ef. \%).

\begin{tabular}{ccccc}
\hline Trat. & UG\% & No-Plant & Prod_Cor.kg ha $\mathbf{~}^{-1}$ & Ef. \% \\
\hline T1 & $13,90 a$ & $274 a$ & $5870 b c$ & \\
T2 & $14,08 a$ & $281 a$ & $5512 c$ & \\
T3 & $14,05 a$ & $277 a$ & $6567 a b$ & $17,28 a$ \\
T4 & $14,33 a$ & $279 a$ & $6981 \mathrm{a}$ & $23,77 \mathrm{a}$ \\
T5 & $14,03 a$ & $268 a$ & $7098 \mathrm{a}$ & $28,37 \mathrm{a}$ \\
T6 & $14,30 \mathrm{a}$ & $268 \mathrm{a}$ & $6931 \mathrm{a}$ & $20,63 \mathrm{a}$ \\
T7 & $14,43 \mathrm{a}$ & $269 \mathrm{a}$ & $6564 \mathrm{ab}$ & $18,38 \mathrm{a}$ \\
T8 & $14,43 \mathrm{a}$ & $261 \mathrm{a}$ & $6706 \mathrm{ab}$ & $20,51 \mathrm{a}$ \\
T9 & $14,25 \mathrm{a}$ & $268 \mathrm{a}$ & $7128 \mathrm{a}$ & $25,93 \mathrm{a}$ \\
T10 & $14,28 \mathrm{a}$ & $264 \mathrm{a}$ & $7047 \mathrm{a}$ & $23,13 \mathrm{a}$ \\
\hline Média & 14,21 & 271 & 6640 & 22.25 \\
Valor F & $0,04 \mathrm{~ns}$ & $0,13 \mathrm{~ns}$ & $<.0001 * *$ & $0,05 \mathrm{~ns}$ \\
CV (\%) & 1,67 & 3.65 & 5,52 & 21,46 \\
DMS & 0,58 & 24.05 & 891,32 & 11,33 \\
\hline
\end{tabular}

T1: Testemunha +Gesso (-N+S), T2: Testemunha absoluta (-N-S), T3: Uréia 45\% N, T4: Uréia + Gesso - 14\%S, T5: Uréia + sulfato de amônio 21\%N/24\%S-(33:00:00+12\%S)*, T6: Nitrato de amônio - NA - 30\%N, T7: Nitrato de amônio - NA - 30\%N + gesso, T8: NA + Sulfato de amônio $21 \% \mathrm{~N} / 24 \% \mathrm{~S}-(27,8: 00: 00+6 \% \mathrm{~S})^{\star \star}$, T9: SAM, T10:FASN - 26\%N/14\%S. Médias contidas nas colunas seguidas de mesma letra não diferem entre si pelo teste $\mathrm{F} .{ }^{*} \mathrm{e}{ }^{* *}$ nível de significância de 5 e $1 \%$ respectivamente de probabilidade. ns: não significativo.

O estande de plantas ficou em 60.000 plantas por hectare, e não foi observada discrepância entre os tratamentos, o que indica que não houve interferência dos tratamentos sobre a emergência e o desenvolvimento das plantas, provavelmente devido à dose de N-P-K aplicada na semeadura ter sido de $450 \mathrm{~kg} \mathrm{ha}^{-1}$ da fórmula 8:28:16 ou seja $36 \mathrm{~kg} \mathrm{~N}$ ha; $126 \mathrm{~kg} \mathrm{P}_{2} \mathrm{O}_{5}$ ha; 72 $\mathrm{kg} \mathrm{K} \mathrm{K}_{2} \mathrm{O}$ ha e o $\mathrm{N}$ mineralizado dos resíduos vegetais ter seguido um padrão gradual de composição (Aita et al., 2001). 


\subsection{Propriedades químicas do solo após a cultura de milho}

Na Tabela 11 são aprepresentado as médias para os macronutrientes e os coeficientes de variação para matéria orgânica $(M O)$, fósforo $(P), p H$, potássio $(\mathrm{K})$, cálcio $(\mathrm{Ca})$, magnésio $(\mathrm{Mn})$, alumínio $(\mathrm{Al})$, acidez potencial $(\mathrm{H}+\mathrm{Al})$, soma de bases (SB), capacidade de troca de cátions (CTC) e saturação por bases (V\%) na camada de 0-20 m após o cultivo de milho respectivamente. Verifica-se que não houve diferença estatística entre os tratamentos avaliados.

Considerando os microrganismos, as fontes nitrogenadas estimulam a decomposição dos carboidratos mais solúveis da palha, favorecendo a biomassa microbiana no solo por meio da disponibilidade de carbono e nitrogênio (Jenkinson \& Ayanaba, 1977; Martin \& Haider, 1980; Siqueira \& Franco, 1988; Killham, 1994; Oliveira et al., 1999). Mediante a disponibilidade de substrato, há aumento na biomassa microbiana e no metabolismo dos microrganismos, principalmente se a fonte de carbono estiver prontamente disponível (Minhoni et al., 1990). Segundo Alvez et al. (1995), a matéria orgânica nos primeiros cinco centímetros de solo sob palha é composta por materiais de fácil decomposição que são mineralizados rapidamente pelos microrganismos.

Valores de pH não apresentaram diferença estatística entre tratamentos, porém os valores médios estiveram baixos, o que pode ter contribuído para menor mineralização da matéria orgânica no processo. Quando o pH é maior, tem-se maior atividade microbiológica e maior mineralização (Edmeades., et al, 1981).

As fontes de $\mathrm{N}$ aplicadas no experimento diminuem o $\mathrm{pH}$ do solo, o que possivelmente contribui para menor mineralização da matéria orgânica no solo. Freitas et al. (1988) verificaram que, na ausência de $\mathrm{N}$ mineral, ocorre a imobilização de $\mathrm{N}^{-\mathrm{NH}_{4}}{ }^{+}$e $\mathrm{N}-\mathrm{NO}_{3}{ }^{-}$. Quando o pH é menor, tem-se menor atividade microbiológica e menor mineralização (Edmeades et al., 1981).

As fontes de $\mathrm{N}$ podem implicar em redução do $\mathrm{pH}$ e o gesso levar ao aumento do Ca trocável, conforme as doses, nas profundidades estudadas. Além da movimentação de Ca, o gesso também proporciona lixiviação de $\mathrm{Mg}$ trocável até à profundidade 0,20 m. A aplicação de doses de gesso aumentou os teores 
de $\mathrm{S}_{-} \mathrm{SO}_{4}{ }^{2-}$ no solo, nas duas profundidades estudadas. Esses resultados concordam com as observações de Raij et al. (1998), que o íon S-SO ${ }_{4}{ }^{2-}$ é fortemente acumulado no subsolo, aí permanecendo por muitos anos.

Na Tabela 11 observa-se que os tratamentos T7 e T9 apresentaram maiores teores de $S$ no solo na camada de $0-20$, porém não diferiram estatisticamente dos demais tratamentos. O sulfato é mais fortemente retido em solos mais ácidos e com menor carga elétrica negativa (Raij \& Peech, 1972). Isto e a repulsão do sulfato por fosfato explicam os teores mais baixos de $\mathrm{S}-\mathrm{SO}_{4}{ }^{2-}$ na superfície do solo. 
Tabela 11. Teores de macronutrientes no solo na profundidade de 0-20 cm após a aplicação dos tratamentos

\begin{tabular}{|c|c|c|c|c|c|c|c|c|c|c|c|c|c|}
\hline Trat. & $\begin{array}{c}\mathrm{pH} \\
\mathrm{Cach}_{2}\end{array}$ & $\begin{array}{l}\text { M.O. } \\
\text { g dm }\end{array}$ & $\begin{array}{l}\mathbf{P} \\
\mathrm{mg}\end{array}$ & $\mathrm{dm}^{-3}$ & \multicolumn{7}{|c|}{ mmol dm } & \multicolumn{2}{|c|}{$\%$} \\
\hline T1 & $5,38 a$ & $27,75 a$ & $21,01 \mathrm{a}$ & $13,08 a$ & $2,13 a$ & $26,25 a$ & $8,25 a$ & $0,25 a$ & $27,25 a$ & $36,75 a$ & $64,00 a$ & $57,75 a$ & $0,50 a$ \\
\hline T2 & $5,35 a$ & $27,25 a$ & $32,63 a$ & $14,72 a$ & $2,28 a$ & $29,75 a$ & $8,00 a$ & $0,25 a$ & $29,25 a$ & $39,75 a$ & $69,00 a$ & $58,25 a$ & $0,50 a$ \\
\hline T3 & $5,55 a$ & $30,00 a$ & $14,42 \mathrm{a}$ & $10,45 a$ & $2,48 a$ & $34,25 a$ & $8,50 a$ & $0,00 a$ & $25,50 a$ & $45,25 a$ & $70,75 a$ & $64,00 a$ & $0,00 a$ \\
\hline T4 & $5,60 a$ & $29,50 a$ & $41,78 a$ & $11,84 a$ & $2,23 a$ & $39,25 a$ & $8,25 a$ & $0,00 a$ & $25 a$ & $50,00 a$ & $72,25 a$ & $68,50 a$ & $0,00 a$ \\
\hline T5 & $5,55 a$ & $26,75 a$ & $15,18 a$ & $10,29 a$ & $1,80 a$ & $39,50 a$ & $7,50 a$ & $0,00 a$ & $22,25 a$ & $49,00 a$ & $71,25 a$ & $65,25 a$ & $0,00 a$ \\
\hline T6 & $5,38 a$ & $27,75 a$ & $14,53 a$ & $9,403 a$ & $2,13 a$ & $26,00 a$ & $7,00 \mathrm{a}$ & $0,25 a$ & $23,50 a$ & $35,25 a$ & $58,75 a$ & $59,50 a$ & $0,75 a$ \\
\hline T7 & $5,15 a$ & $26,50 a$ & $18,17 a$ & $13,74 a$ & $1,38 a$ & $21,00 a$ & $6,75 a$ & $1,00 a$ & $28,50 a$ & $29,25 a$ & $57,75 a$ & $50,00 a$ & $3,50 a$ \\
\hline T8 & $5,18 a$ & $26,25 a$ & $28,06 a$ & $11,72 \mathrm{a}$ & $1,75 a$ & 23 & $7,25 a$ & $0,50 a$ & & $0 a$ & $5 a$ & $51,50 a$ & $1,50 a$ \\
\hline T9 & $5,30 a$ & $27,70 a$ & $19,85 a$ & $16,18 a$ & $1,83 a$ & $28,50 a$ & $7,25 a$ & $0,75 a$ & $26,75 a$ & $37,50 a$ & $64,25 a$ & $57,25 a$ & $2,50 a$ \\
\hline T10 & $5,25 a$ & $26,00 a$ & $24,15 a$ & $12,86 a$ & $1,58 a$ & $21,25 a$ & $6,25 a$ & $0,25 a$ & $26,00 a$ & $29,00 a$ & $55,00 a$ & $53,00 a$ & $1,25 a$ \\
\hline Média & 5,37 & 27,48 & 21,98 & 12,43 & 1,96 & 28,95 & 7,50 & 0,33 & 26,20 & 38,43 & 64,63 & 58,50 & 1,05 \\
\hline Valor F (\%) & $0,12 \mathrm{~ns}$ & $0,05 n s$ & $0,90 \mathrm{~ns}$ & $1,19 \mathrm{~ns}$ & $1,84 \mathrm{~ns}$ & $1,77 \mathrm{~ns}$ & $2,24 \mathrm{~ns}$ & $1,62 \mathrm{~ns}$ & 1,31ns & $1,92 \mathrm{~ns}$ & $1,58 \mathrm{~ns}$ & $1,89 \mathrm{~ns}$ & $1,65 \mathrm{~ns}$ \\
\hline CV (\%) & 4,43 & 7,32 & 94,15 & 31,19 & 25,94 & 35,08 & 13,11 & 161,90 & 19,37 & 28,46 & 15,04 & 15,08 & 173,88 \\
\hline DMS & 0,58 & 4,89 & 50,33 & 9,43 & 1,23 & 24,70 & 2,39 & 1,28 & 12,34 & 26,60 & 23,65 & 21,45 & 4,44 \\
\hline
\end{tabular}

T1: Testemunha +Gesso (-N+S), T2: Testemunha absoluta (-N-S), T3: Uréia - 45\% N, T4: Uréia + Gesso -14\%S, T5: Uréia + sulfato de amônio - 21\%N/24\%S-(33:00:00+12\%S) ${ }^{\star}$, T6: Nitrato de amônio - NA - 30\%N, T7: Nitrato de amônio - NA - 30\%N + gesso, T8: NA + Sulfato de amônio

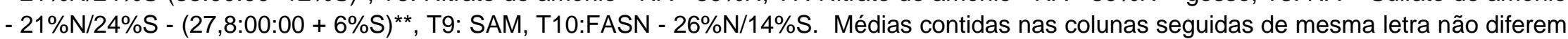
entre si pelo teste $\mathrm{F}$. nível de significância de 1\% respectivamente de probabilidade. ns: não significativo. 
$\mathrm{Na}$ Tabela 12 tem-se os resultados da análise do solo para micronutrientes, amostrados na camada de 0-20 cm. Não houve diferenças significativas entre os tratamentos para os B, Cu, Fe, Mn e Zn.

Tabela 12. Teores de micronutrientes no solo na profundidade de $0-20 \mathrm{~cm}$ após a aplicação dos tratamentos

\begin{tabular}{cccccc}
\hline & B & Cu & Fe & Mn & Zn \\
\cline { 2 - 6 } Trat. & \multicolumn{5}{c}{$\mathbf{m g ~ d m}^{-3}$} \\
T1 & $0,31 \mathrm{a}$ & $5,48 \mathrm{a}$ & $15,00 \mathrm{a}$ & $28,10 \mathrm{a}$ & $2,85 \mathrm{a}$ \\
T2 & $0,32 \mathrm{a}$ & $5,33 \mathrm{a}$ & $15,50 \mathrm{a}$ & $27,38 \mathrm{a}$ & $2,00 \mathrm{a}$ \\
T3 & $0,32 \mathrm{a}$ & $5,23 \mathrm{a}$ & $13,00 \mathrm{a}$ & $25,58 \mathrm{a}$ & $2,70 \mathrm{a}$ \\
T4 & $0,30 \mathrm{a}$ & $5,33 \mathrm{a}$ & $14,50 \mathrm{a}$ & $27,15 \mathrm{a}$ & $2,03 \mathrm{a}$ \\
T5 & $0,30 \mathrm{a}$ & $4,60 \mathrm{a}$ & $13,25 \mathrm{a}$ & $25,90 \mathrm{a}$ & $2,03 \mathrm{a}$ \\
T6 & $0,38 \mathrm{a}$ & $4,70 \mathrm{a}$ & $12,50 \mathrm{a}$ & $28,93 \mathrm{a}$ & $1,90 \mathrm{a}$ \\
T7 & $0,38 \mathrm{a}$ & $4,50 \mathrm{a}$ & $15,00 \mathrm{a}$ & $24,83 \mathrm{a}$ & $1,75 \mathrm{a}$ \\
T8 & $0,30 \mathrm{a}$ & $4,45 \mathrm{~b}$ & $13,00 \mathrm{a}$ & $25,50 \mathrm{a}$ & $1,60 \mathrm{a}$ \\
T9 & $0,30 \mathrm{a}$ & $4,90 \mathrm{a}$ & $13,00 \mathrm{a}$ & $25,60 \mathrm{a}$ & $1,68 \mathrm{a}$ \\
T10 & $0,29 \mathrm{a}$ & $4,85 \mathrm{a}$ & $14,25 \mathrm{a}$ & $25,60 \mathrm{a}$ & $1,90 \mathrm{a}$ \\
\hline Média & 0,32 & 4,94 & 13,90 & 26,46 & 2,04 \\
Valor F (\%) & $0,65 \mathrm{~ns}$ & $1,17 \mathrm{~ns}$ & $1,30 \mathrm{~ns}$ & $0,35 \mathrm{~ns}$ & $0,88 \mathrm{~ns}$ \\
CV (\%) & 26,45 & 14,15 & 13,47 & 17,29 & 43,20 \\
DMS & 0,20 & 1,70 & 4,56 & 11,12 & 2,15 \\
\hline
\end{tabular}

T1: Testemunha +Gesso (-N+S), T2: Testemunha absoluta (-N-S), T3: Uréia 45\% N, T4: Uréia + Gesso - 14\%S, T5: Uréia + sulfato de amônio 21\%N/24\%S-(33:00:00+12\%S)*, T6: Nitrato de amônio - NA - 30\%N, T7: Nitrato de amônio - NA - 30\%N + gesso, T8: NA + Sulfato de amônio $21 \% \mathrm{~N} / 24 \% \mathrm{~S}-(27,8: 00: 00+6 \% \mathrm{~S})^{\star \star}$, T9: SAM, T10:FASN - 26\%N/14\%S. Médias contidas nas colunas seguidas de mesma letra não diferem entre si pelo teste $\mathrm{F}$. nível de significância de 1\% respectivamente de probabilidade. ns: não significativo.

Existe interação entre $\mathrm{N} x$ versos micronutrientes, por esse motivo, sua falta ou excesso provoca deficiência nos tecidos da plantas. O N encontra-se na lista dos macronutrientes não metálicos e exerce uma função importante na planta participando nos Aminoácidos, proteínas, enzimas, DNA e RNA (purinas e pirimidinas), clorofila, coenzimas, colina, ácido indolilacético. 
A Tabela 13 mostra resultados analíticos de amostras de solo na profundidade de 20-40 depois da coleta do milho. Verifica-se que houve diferença estatística significativa para o potencial de hidrogênio iônico $(\mathrm{pH})$, teores de cálcio $(\mathrm{Ca})$, soma de base (SB) e saturação por bases (V\%).

Os tratamentos T7, T8, T9 e T10 apresentaram menores valores de $\mathrm{pH}$, comparando com outros tratamentos incluindo as testemunhas que não receberam adubação nitrogenada, verifica-se que T1, T2, T3 e T6 não diferiram entre si e apresentaram valores de $\mathrm{pH}$ intermediários, enquanto que T4 e T5 também não diferiram entre si e apresentaram maiores valores de $\mathrm{pH}$. Os tratamentos T6; T7; T8, T9 e T10 deferiram estatisticamente dos tratamentos T4 e T5. As diferenças encontradas para o $\mathrm{pH} \mathrm{CaCl}_{2}$, de forma que a fonte sulfato de amônio apresente a tendência de acidificar o solo, o que pode ter levado a esse comportamento, enquanto que a uréia pode levar a aumento do $\mathrm{pH}$.

Para o teor de matéria orgânica matéria orgânica $(M O)$, fósforo $(P)$, enxofre $(\mathrm{S})$, potássio $(\mathrm{K})$, magnésio $(\mathrm{Mg})$, alumínio $(\mathrm{Al})$, acidez potencia $(\mathrm{H}+\mathrm{Al})$, capacidade de troca de cátions (CTC) e saturação por alumínio (m) verifica-se que não houve diferença estatística significativa entre os tratamentos.

Para o cálcio $\left(\mathrm{Ca}^{2+}\right)$, verifica-se que também houve diferença significativa entre os tratamentos. A maior média obtida em T5 não diferiram entre si, deve-se aplicação de gesso juntamente com a uréia e T5. Os tratamentos T1, T2, T6 e T7 apresentaram teores intermediários e os tratamentos T8, T9 e T10 apresentaram menores teores. A maior média de cálcio $\left(\mathrm{Ca}^{2+}\right)$ foi para o $\mathrm{T} 5$, devido provavelmente a ação conjunta de uréia e gesso, o que refletiu na SB e V\%.

A soma de base (SB) verifica-se que houve diferenças estatísticas significativa. Os tratamentos T8, T9 e T10 apresentaram menores teores de SB, T4 e T5 apresentaram maiores teores, T1, T2, T3, T6 e T7 apresentaram teores intermediários. Para a capacidade de troca de cátions (CTC) não houve diferenças estatísticas significativas entre os tratamentos. A saturação por base (V\%), verifica-se que houve diferenças estatísticas significativas entre os tratamentos, T8 apresentou menor teor de V\% comparando com outros 
tratamentos, o tratamento T5 apresentou maior teor de V\% e o resto dos tratamentos aprestaram teores intermediários. Não houve diferenças estatísticas significativa em quanto a saturação por alumínio ( $\mathrm{m} \%)$. Os tratamentos T4 e T5 apresentaram menores teores de m (\%) e T1, T7 e T8 apresentaram maiores teores T2, T3, T6, T9 e T10 apresentaram teores intermediários. 
Tabela 13. Atributos químicos do solo na profundidade de $20-40 \mathrm{~cm}$ após aplicação dos tratamentos

\begin{tabular}{|c|c|c|c|c|c|c|c|c|c|c|c|c|c|}
\hline \multirow[b]{2}{*}{ Trat. } & \multirow{2}{*}{$\begin{array}{c}\mathrm{pH} \\
\mathrm{Cacl}_{2}\end{array}$} & \multirow{2}{*}{$\begin{array}{l}\text { M.O. } \\
\text { g dm }^{3}\end{array}$} & $\mathbf{P}$ & $\mathrm{S}$ & $\mathrm{K}$ & $\mathrm{Ca}$ & Mg & Al & $\mathrm{H}+\mathrm{Al}$ & SB & CTC & V & $\mathbf{m}$ \\
\hline & & & \multicolumn{2}{|c|}{$\mathrm{mg} \mathrm{dm}^{-3}$} & \multicolumn{7}{|c|}{$\mathrm{mmol}_{\mathrm{c}} \mathrm{dm}^{-3}$} & \multicolumn{2}{|c|}{$\%$} \\
\hline T1 & $5,05 a b$ & $22,00 a$ & $5,25 a$ & $20,00 a$ & $1,48 a$ & $18,50 a b$ & $5,75 a$ & $1,00 a$ & $25,75 a$ & $26,00 a b$ & $51,75 a$ & $48,75 a b$ & $5,25 a$ \\
\hline T2 & $5,05 a b$ & $22,50 a$ & $9,50 a$ & $12,75 a$ & $1,38 a$ & $19,50 a b$ & $6,25 a$ & $0,75 a$ & $28,50 a$ & $27,25 a b$ & $55,75 a$ & $48,50 a b$ & $2,50 a$ \\
\hline T3 & $5,08 a b$ & $22,25 a$ & $6,25 a$ & $22,75 a$ & $1,10 a$ & $20,50 a b$ & $5,75 a$ & $1,00 a$ & $26,00 a$ & $27,50 a b$ & $53,50 a$ & $50,75 a b$ & $3,75 a$ \\
\hline T4 & $5,23 a$ & $23,00 a$ & $9,25 a$ & $19,75 a$ & $1,63 a$ & $22,25 a b$ & $6,25 a$ & $0,50 a$ & $21,50 a$ & $30,25 a b$ & $51,75 a$ & $57,25 a b$ & $1,75 a$ \\
\hline T5 & $5,53 a$ & $24,50 a$ & $11,25 a$ & $13,75 a$ & $1,43 a$ & $32,25 a$ & $6,75 a$ & $0,50 a$ & $19,50 a$ & $40,25 a$ & $9,75 a$ & $64,75 a$ & $1,75 a$ \\
\hline T6 & $5,08 a b$ & $22,25 a$ & $5,25 a$ & $13,00 \mathrm{a}$ & $1,30 a$ & $17,25 a b$ & $5,75 a$ & $1,00 a$ & $24,75 a$ & $24,25 a b$ & $49,00 a$ & $49,25 a b$ & $3,75 a$ \\
\hline T7 & $4,88 b$ & $21,75 a$ & $9,00 \mathrm{a}$ & $20,75 a$ & $1,20 a$ & $16,25 a b$ & $5,75 a$ & $1,00 a$ & $28,00 a$ & $23,00 a b$ & $51,00 a$ & $44,25 a b$ & $5,75 a$ \\
\hline T8 & $4,88 b$ & $21,75 a$ & $5,75 a$ & $18,25 a$ & $1,28 a$ & $13,75 b$ & $5,25 a$ & $1,00 a$ & $32,25 a$ & $20,25 b$ & $52,50 a$ & $39,50 b$ & $5,25 a$ \\
\hline T9 & $4,98 a b$ & $21,50 a$ & $4,50 a$ & $21,25 a$ & $1,15 a$ & $14,00 \mathrm{~b}$ & $5,50 a$ & $0,75 a$ & $23,75 a$ & $20,50 b$ & $44,25 a$ & $46,25 a b$ & $4,25 a$ \\
\hline T10 & $4,83 b$ & $21,50 \mathrm{a}$ & $6,00 a$ & $26,50 a$ & $1,30 a$ & $13,75 b$ & $5,25 a$ & $0,75 a$ & $28,00 \mathrm{a}$ & $20,25 b$ & $48,25 a$ & $42,25 a$ & $4,25 a$ \\
\hline Média & 5,06 & 22,30 & 7,20 & 18,88 & 1,32 & 18,80 & 5,83 & 0,83 & 25,80 & 25,95 & 51,75 & 49,15 & 3,83 \\
\hline Valor $F(\%)$ & $0,04^{*}$ & $1,48 \mathrm{~ns}$ & $2,11 \mathrm{~ns}$ & $0,92 n s$ & $1,09 \mathrm{~ns}$ & $2,52^{\star}$ & $0,64 \mathrm{~ns}$ & $0,41 \mathrm{~ns}$ & $1,62 \mathrm{~ns}$ & $2,49^{\star}$ & $1,10 \mathrm{~ns}$ & $2,55^{*}$ & $0,68 \mathrm{~ns}$ \\
\hline CV (\%) & 4,89 & 6,66 & 44,40 & 49,87 & 22,93 & 37,33 & 20,33 & 77,98 & 22,42 & 29,70 & 15,54 & 18,69 & 90,80 \\
\hline DMS & 0,60 & 3,61 & 7,78 & 22,89 & 0,74 & 17,07 & 2,88 & 1,56 & 14,07 & 18,74 & 19,56 & 22,35 & 8,45 \\
\hline
\end{tabular}

T1: Testemunha +Gesso (-N+S), T2: Testemunha absoluta (-N-S), T3: Uréia - 45\% N, T4: Uréia + Gesso - 14\%S, T5: Uréia + sulfato de amônio - 21\%N/24\%S-(33:00:00+12\%S)*, T6: Nitrato de amônio - NA - 30\%N, T7: Nitrato de amônio - NA - 30\%N + gesso, T8: NA + Sulfato de amônio - 21\%N/24\%S - $(27,8: 00: 00+6 \% S)^{\star \star}$, T9: SAM, T10:FASN - 26\%N/14\%S. Médias de cinco repetições contidas em colunas, seguidas de mesma letra não diferem entre sim pelo teste F. **: nível de significância de 5 a $1 \%$ respectivamente de probabilidade. ns: não significativo. 


\subsection{Características bromatológicas de milho}

Várias são as análises químicas que podem ser utilizadas para avaliar a qualidade nutricional dos alimentos, sendo as de maior importância a proteína bruta (PB), fibra detergente ácido (FDA), fibra detergente neutro (FDN). A PB indica o nível protéico do grão de milho, cujos valores devem estar entre 6 a 9\%. A fibra em detergente neutro (FDN), é constituída, de celulose, hemicelulose, lignina e proteína danificada pelo calor e parte da proteína da parede celular e minerais. VAN SOEST (1967), obteve um resíduo insolúvel no detergente ácido denominado fibra em detergente ácido (FDA), constituída em sua quase totalidade, de celulose e lignina (lignocelulose), de proteína danificada pelo calor e parte da proteína da parede celular e de minerais insolúveis (cinzas). Os teores de matéria seca, PB, FDA, FDN no grão do milho não diferiram significativamente entre os tratamentos (Tabela 14). Estes resultados coincidem com os encontrado por Wagner et al. (2001) quando estudaram a composição química dos alimentos (Msgão\% 87,9; PB\% 10,7; FDA\% 2,2 e FDN\% 13,2). 
Tabela 14. Teores e (\%) matéria seca no grão (msgrão), proteína bruta (PB), fibra em detergente ácido (FDA), fibra em detergente neutro no grão de milho após da colheita.

\begin{tabular}{ccccc}
\hline Tratamentos & msgão(\%) & PB(\%) & FDA(\%) & FDN(\%) \\
\hline T1 & $90,40 \mathrm{a}$ & $9,23 \mathrm{a}$ & $2,95 \mathrm{a}$ & $13,05 \mathrm{a}$ \\
T2 & $90,17 \mathrm{a}$ & $9,28 \mathrm{a}$ & $4,80 \mathrm{a}$ & $12,55 \mathrm{a}$ \\
T3 & $93,58 \mathrm{a}$ & $9,41 \mathrm{a}$ & $3,84 \mathrm{a}$ & $19,54 \mathrm{a}$ \\
T4 & $94,03 \mathrm{a}$ & $9,23 \mathrm{a}$ & $4,40 \mathrm{a}$ & $12,12 \mathrm{a}$ \\
T5 & $90,07 \mathrm{a}$ & $9,94 \mathrm{a}$ & $5,24 \mathrm{a}$ & $16,86 \mathrm{a}$ \\
T6 & $92,28 \mathrm{a}$ & $9,18 \mathrm{a}$ & $4,18 \mathrm{a}$ & $14,33 \mathrm{a}$ \\
T7 & $91,20 \mathrm{a}$ & $9,73 \mathrm{a}$ & $3,75 \mathrm{a}$ & $14,36 \mathrm{a}$ \\
T8 & $91,79 \mathrm{a}$ & $9,53 \mathrm{a}$ & $3,99 \mathrm{a}$ & $17,64 \mathrm{a}$ \\
T9 & $90,65 \mathrm{a}$ & $9,68 \mathrm{a}$ & $4,96 \mathrm{a}$ & $16,64 \mathrm{a}$ \\
T10 & $90,96 \mathrm{a}$ & $9,70 \mathrm{a}$ & $4,94 \mathrm{a}$ & $17,82 \mathrm{a}$ \\
\hline Média & 91,51 & 9,49 & 4,30 & 15,49 \\
Valor F (\%) & $0,26 \mathrm{~ns}$ & $0,19 \mathrm{~ns}$ & $0,77 \mathrm{~ns}$ & $0,73 \mathrm{~ns}$ \\
CV (\%) & 2,63 & 4,52 & 41,64 & 40,10 \\
DMS & 5,86 & 1,04 & 4,36 & 15,11 \\
\hline
\end{tabular}

T1: Testemunha +Gesso (-N+S), T2: Testemunha absoluta (-N-S), T3: Uréia 45\% N, T4: Uréia + Gesso - 14\%S, T5: Uréia + sulfato de amônio 21\%N/24\%S-(33:00:00+12\%S)*, T6: Nitrato de amônio - NA - 30\%N, T7: Nitrato de amônio - NA - 30\%N + gesso, T8: NA + Sulfato de amônio $21 \% N / 24 \% S-(27,8: 00: 00+6 \% S)^{\star \star}$, T9: SAM, T10:FASN - 26\%N/14\%S. Médias contidas nas colunas seguidas de mesma letra não diferem entre si pelo teste $F$. * e ** nível de significância de 5 e $1 \%$ respectivamente de probabilidade. ns: não significativo.

No presente estudo não se obteve diferenças significativas entre os tratamentos testados, embora esperasse que a aplicação de fontes nitrogenadas resultaria em aumentos nos teores de PB. 


\section{Conclusão}

Considerando-se os resultados obtidos no presente estudo, pode-se tecer as seguintes conclusões:

a) das fontes nitrogenadas avaliadas a uréia implicou em maiores perdas de nitrogênio $\mathrm{N}-\mathrm{NH}_{3}$;

b) os níveis de perdas para $\mathrm{N}-\mathrm{NH}_{3}$ para uréia e as maiores perdas ocorreram aos 6 dias após aplicação;

c) a ocorrência de precipitação $29,8 \mathrm{~mm}$ antes e 47,4 $\mathrm{mm}$ após a aplicação dos fertilizantes nitrogenados favoreceram no sentido de se obter pequenas perdas de nitrogênio $\mathrm{N}-\mathrm{NH}_{3}$;

d) a utilização da adubação nitrogenada de cobertura no milho implicou em maiores teores foliares de nitrogênio $(N)$, sem no entanto elevar os valores da proteína bruta, porém levou à maiores produtividades $(\mathrm{kg} / \mathrm{ha})$ do milho;

e) observou-se redução nos valores do $\mathrm{pH} \mathrm{CaCl}$ do solo, principalmente na camada de $20-40 \mathrm{~cm}$ para o sulfato de amônio;

f) com relação ao desempenho geral das fontes de nitrogênio, pode-se constatar que o FASN teve comportamento similar ao do sulfato de amônio e do nitrato de amônio. 
Anexos 
Anexo A

Tabela 14. Dados climáticos do ano 2006

\begin{tabular}{|c|c|c|c|c|c|c|c|c|c|c|c|c|c|c|c|c|c|c|}
\hline \multirow[b]{2}{*}{ DATA } & \multicolumn{2}{|c|}{ TEMP MAX } & \multicolumn{2}{|c|}{ TEMP MIN } & \multirow{2}{*}{$\begin{array}{l}\begin{array}{l}\text { TEMP } \\
\text { MÉD }\end{array} \\
\text { graus }\end{array}$} & \multicolumn{2}{|c|}{ VENTO MÉD } & \multicolumn{2}{|c|}{$\begin{array}{c}\text { VENTO } \\
\text { MAX }\end{array}$} & \multicolumn{3}{|c|}{ UMIDADE } & \multicolumn{3}{|c|}{ PRESSÃO ATM } & \multirow{2}{*}{$\begin{array}{c}\text { CHUVA } \\
\mathrm{mm}\end{array}$} & \multicolumn{2}{|c|}{$\begin{array}{c}\text { RADIAÇÃO } \\
\text { MAX }\end{array}$} \\
\hline & graus & hora & graus & hora & & Direção & $\mathrm{km} / \mathrm{h}$ & $\mathrm{km} / \mathrm{h}$ & hora & Mín & Máx & Média & Mín & $\operatorname{Max}$ & $\begin{array}{l}\text { média - } \\
\text { Milibar }\end{array}$ & & hora & $\mathrm{W} / \mathrm{m} 2$ \\
\hline $1 / 12 / 2006$ & 30,63 & $15: 50$ & 18,4 & $05: 20$ & 24,16 & 161,08 & 17,784 & 41,29 & 20:05 & 41,74 & 83,50 & 62,64 & 941 & 944 & 942,63 & 0 & $12: 10$ & 1061 \\
\hline $2 / 12 / 2006$ & 28,91 & $11: 30$ & 17,87 & 05:40 & 23,65 & 106,46 & 10,8 & 38,41 & $11: 30$ & 49,57 & 85,10 & 67,14 & 942 & 946 & 943,39 & 0 & $11: 30$ & 1131 \\
\hline $3 / 12 / 2006$ & 31,89 & $15: 50$ & 20,83 & $05: 20$ & 24,97 & 185,34 & 6,5052 & 26,89 & $16: 45$ & 41,26 & 91,40 & 72,21 & 940 & 945 & 943,06 & 2,6 & $12: 10$ & 1279 \\
\hline $4 / 12 / 2006$ & 30,32 & $12: 50$ & 20 & 22:20 & 23,87 & 177,6 & 9 & 32,65 & $12: 13$ & 47,16 & 93,40 & 76,78 & 941 & 945 & 943,42 & 22,4 & $11: 00$ & 1340 \\
\hline $5 / 12 / 2006$ & 27,31 & $15: 40$ & 19,96 & 02:50 & 22,82 & 264,36 & 7,74 & 32,65 & 17:08 & 61,42 & 93,90 & 82,02 & 943 & 946 & 944,27 & 2 & $10: 20$ & 1005 \\
\hline $6 / 12 / 2006$ & 27,53 & $17: 10$ & 18,78 & 23:30 & 23,64 & 264,97 & 11,376 & 44,17 & 21:49 & 61,60 & 93,30 & 78,92 & 939 & 945 & 942,28 & 25,8 & 09:50 & 752 \\
\hline $7 / 12 / 2006$ & 25,46 & $15: 50$ & 18,42 & 02:00 & 21,72 & 206,09 & 9,7488 & 32,65 & 21:30 & 62,38 & 94,30 & 81,47 & 938 & 943 & 940,14 & 22,4 & $14: 40$ & 895 \\
\hline $8 / 12 / 2006$ & 29,98 & $16: 30$ & 17,24 & 05:10 & 23,47 & 162,36 & 8,64 & 26,89 & 22:44 & 44,76 & 88,60 & 71,1 & 938 & 943 & 940,27 & 0 & $12: 50$ & 1106 \\
\hline $9 / 12 / 2006$ & 27 & $14: 50$ & 20,35 & $06: 30$ & 22,64 & 142,48 & 6,9984 & 24,02 & $23: 57$ & 64,17 & 92,80 & 83,4 & 939 & 942 & 940,56 & 2,8 & 11:00 & 999 \\
\hline $10 / 12 / 2006$ & 29,82 & $16: 30$ & 19,56 & 05:30 & 24,6 & 146,66 & 10,512 & 41,29 & 21:02 & 48,75 & 91,80 & 73,19 & 938 & 942 & 940,45 & 0 & $11: 10$ & 1179 \\
\hline $11 / 12 / 2006$ & 30,56 & $15: 10$ & 19,8 & $05: 50$ & 24,63 & 155,4 & 13,212 & 38,41 & $19: 15$ & 48,82 & 89,60 & 67,78 & 940 & 944 & 941,83 & 4 & 1:50 & 1075 \\
\hline $12 / 12 / 2006$ & 28,39 & $14: 40$ & 19,19 & $05: 40$ & 23,91 & 133,9 & 6,6 & 26,89 & 06:26 & 55,84 & 91,60 & 73,65 & 941 & 945 & 943 & 4,8 & $12: 40$ & 1051 \\
\hline $13 / 12 / 2006$ & 29,64 & $14: 10$ & 19,12 & $04: 40$ & 23,95 & 132,46 & 9,864 & 29,77 & $10: 51$ & 54,86 & 91,60 & 76,78 & 940 & 945 & 942,69 & 4,6 & $14: 00$ & 1123 \\
\hline $14 / 12 / 2006$ & 26,73 & $12: 30$ & 21,17 & $14: 00$ & 23,07 & 188,45 & 6,4368 & 41,29 & 12:57 & 71,20 & 92,00 & 84,82 & 941 & 945 & 942,88 & 13,2 & $12: 50$ & 1021 \\
\hline $15 / 12 / 2006$ & 29,95 & $16: 30$ & 21,56 & $23: 40$ & 24,18 & 182,78 & 6,408 & 29,77 & $13: 52$ & 56,47 & 92,50 & 81,98 & 940 & 946 & 942,91 & 7,2 & $10: 50$ & 1037 \\
\hline $16 / 12 / 2006$ & 30,88 & $16: 50$ & 19,36 & 05:00 & 24,94 & 210,93 & 5,8284 & 26,89 & $10: 40$ & 47,74 & 93,30 & 75,97 & 940 & 945 & 942,46 & 0,2 & $13: 00$ & 1162 \\
\hline $17 / 12 / 2006$ & 31,73 & $16: 10$ & 20,99 & $04: 20$ & 25,94 & 238,11 & 7,56 & 24,02 & 08:23 & 46,50 & 92,50 & 73,69 & 941 & 946 & 942,77 & 0 & $13: 40$ & 1060 \\
\hline $18 / 12 / 2006$ & 31,76 & $16: 50$ & 21,49 & $04: 40$ & 25,2 & 154,28 & 7,812 & 41,29 & $17: 45$ & 46,15 & 92,60 & 76,98 & 940 & 945 & 942,47 & 19 & $11: 40$ & 1121 \\
\hline $19 / 12 / 2006$ & 30,79 & $14: 40$ & 20,82 & $01: 20$ & 23,96 & 223,48 & 8,964 & 38,41 & 17:33 & 52,77 & 92,60 & 79,64 & 942,18 & 944 & 939 & 2,6 & $12: 40$ & 1127 \\
\hline $20 / 12 / 2006$ & 26,85 & $17: 10$ & 20,92 & 03:30 & 23,22 & 270,41 & 8,2656 & 49,9 & $13: 28$ & 68,14 & 92,40 & 85,02 & 941 & 945 & 943,42 & 10,6 & $12: 40$ & 866 \\
\hline $21 / 12 / 2006$ & 27,58 & $16: 40$ & 21,57 & 04:00 & 23,99 & 267,43 & 11,268 & 47,05 & $11: 35$ & 57,45 & 90,70 & 79,62 & 943 & 947 & 944,69 & 1 & $12: 20$ & 919 \\
\hline 22/12/2006 & 29,5 & $16: 20$ & 20,64 & 23:10 & 23,57 & 189,25 & 6,876 & 26,89 & 22:36 & 58,88 & 92,90 & 83,5 & 943 & 947 & 945,34 & 14,2 & 09:30 & 1025 \\
\hline 23/12/2006 & 29,39 & $12: 10$ & 20,72 & $00: 00$ & 23,11 & 160,12 & 6,3288 & 32,65 & 13:13 & 57,28 & 94,00 & 84,74 & 942 & 946 & 944,06 & 2,4 & $11: 50$ & 1145 \\
\hline
\end{tabular}




\begin{tabular}{|c|c|c|c|c|c|c|c|c|c|c|c|c|c|c|c|c|c|c|}
\hline $24 / 12 / 2006$ & 30,78 & $16: 50$ & 20,7 & 01:30 & 25,21 & 241,7 & 10,656 & 64,3 & 21:45 & 51,67 & 93,10 & 75,17 & 940 & 945 & 942,93 & 2,8 & $12: 50$ & 1074 \\
\hline $25 / 12 / 2006$ & 31,05 & 13:50 & 20,07 & 05:20 & 23,48 & 215,24 & 8,5428 & 61,42 & 17:01 & 54,52 & 93,90 & 81,43 & 941 & 945 & 943,34 & 45,4 & $11: 30$ & 1070 \\
\hline $26 / 12 / 2006$ & 30,45 & $16: 10$ & 19,35 & $05: 20$ & 24,05 & 239,5 & 9,468 & 38,41 & 17:55 & 50,58 & 93,70 & 77,8 & 941 & 945 & 943,08 & 0 & $12: 00$ & 1091 \\
\hline $27 / 12 / 2006$ & 30,65 & 13:50 & 20,1 & $01: 20$ & 23,08 & 199,54 & 7,092 & 49,9 & 13:56 & 51,09 & 92,90 & 81,52 & 943 & 947 & 944,29 & 1,4 & $13: 20$ & 1098 \\
\hline $28 / 12 / 2006$ & 29 & $15: 00$ & 20,15 & 05:00 & 24,2 & 174,45 & 7,6896 & 35,53 & 18:33 & 55,69 & 92,50 & 76,47 & 943 & 948 & 945,97 & 1 & $11: 50$ & 1125 \\
\hline 29/12/2006 & 30,27 & $15: 00$ & 20,24 & 05:40 & 25,03 & 148,26 & 12,168 & 35,53 & 20:49 & 46,44 & 90,10 & 68,41 & 943 & 948 & 945,54 & 0 & $13: 30$ & 1127 \\
\hline $30 / 12 / 2006$ & 27,1 & $11: 40$ & 20,74 & 05:50 & 22,31 & 139,3 & 8,316 & 24,02 & $12: 24$ & 64,03 & 93,40 & 84,41 & 944 & 947 & 945,31 & 28 & $11: 30$ & 597,1 \\
\hline $31 / 12 / 2006$ & 22,23 & $15: 10$ & 20,22 & $21: 50$ & 21,15 & 134,02 & 4,5972 & 35,53 & $10: 48$ & 90,70 & 93,90 & 92,81 & 943 & 946 & 944,71 & 62 & $14: 50$ & 356,4 \\
\hline
\end{tabular}


Anexo B

Tabela 15. Dados climáticos do ano 2007

\begin{tabular}{|c|c|c|c|c|c|c|c|c|c|c|c|c|c|c|c|c|c|c|}
\hline \multirow[b]{2}{*}{ DATA } & \multicolumn{2}{|c|}{ TEMP MAX } & \multicolumn{2}{|c|}{ TEMP MIN } & \multirow{2}{*}{$\begin{array}{l}\text { TEMP } \\
\text { MÉD } \\
\text { graus }\end{array}$} & \multicolumn{2}{|c|}{ VENTO MÉD } & \multicolumn{2}{|c|}{$\begin{array}{c}\text { VENTO } \\
\text { MAX }\end{array}$} & \multicolumn{3}{|c|}{ UMIDADE } & \multicolumn{3}{|c|}{ PRESSÃO ATM } & \multirow{2}{*}{$\begin{array}{c}\text { CHUVA } \\
\mathrm{mm}\end{array}$} & \multicolumn{2}{|c|}{$\begin{array}{c}\text { RADIAÇÃO } \\
\text { MAX }\end{array}$} \\
\hline & graus & hora & graus & hora & & Direção & $\mathrm{km} / \mathrm{h}$ & km/h & hora & Mín & Máx & Média & Mín & $\operatorname{Max}$ & $\begin{array}{c}\text { média } \\
\text { - } \\
\text { Milibar }\end{array}$ & & hora & $\mathrm{W} / \mathrm{m} 2$ \\
\hline $1 / 1 / 2007$ & 23,85 & $16: 30$ & 20,26 & 06:00 & 21,44 & 128,23 & 7,99 & 32,65 & $10: 23$ & 75,70 & 94,10 & 89,19 & 943,00 & 945,00 & 943,90 & 19,40 & 11:00 & 491 \\
\hline $2 / 1 / 2007$ & 24,22 & $16: 20$ & 19,81 & 22:50 & 21,19 & 181,31 & 8,17 & 29,77 & $18: 22$ & 78,70 & 93,80 & 90,14 & 944,00 & 947,00 & 945,41 & 12,60 & $13: 40$ & 592 \\
\hline $3 / 1 / 2007$ & 24,78 & $17: 10$ & 19,83 & 05:30 & 21,87 & 282,84 & 7,90 & 41,29 & $13: 43$ & 78,10 & 93,40 & 88,65 & 942,00 & 946,00 & 944,06 & 4,20 & $16: 20$ & 594 \\
\hline $4 / 1 / 2007$ & 27,25 & $13: 30$ & 20,66 & 04:10 & 22,91 & 284,97 & 10,84 & 32,65 & 09:41 & 65,61 & 92,80 & 83,42 & 939,00 & 944,00 & 941,81 & 1,20 & $12: 20$ & 1033 \\
\hline $5 / 1 / 2007$ & 23,35 & $12: 30$ & 20,07 & 05:50 & 21,39 & 235,47 & 9,32 & 32,65 & $12: 47$ & 77,50 & 92,90 & 89,96 & 939,00 & 942,00 & 940,95 & 17,20 & $10: 10$ & 469 \\
\hline $6 / 1 / 2007$ & 22,59 & $16: 10$ & 20,33 & 06:00 & 21,27 & 239,03 & 10,18 & 32,65 & $12: 19$ & 81,70 & 93,20 & 89,78 & 940,00 & 943,00 & 941,43 & 18,20 & $13: 40$ & 276 \\
\hline $7 / 1 / 2007$ & 28,86 & $14: 10$ & 21,01 & 00:00 & 23,63 & 235,11 & 8,60 & 35,53 & $17: 53$ & 60,06 & 92,40 & 82,72 & 942,00 & 946,00 & 943,94 & 5,20 & $12: 40$ & 1086 \\
\hline $8 / 1 / 2007$ & 30,61 & $16: 00$ & 19,77 & $23: 20$ & 24,34 & 225,87 & 8,10 & 38,41 & $21: 26$ & 51,61 & 94,00 & 79,07 & 941,00 & 946,00 & 943,74 & 44,60 & $12: 50$ & 1083 \\
\hline 9/1/2007 & 30,43 & $15: 40$ & 19,71 & 03:20 & 24,31 & 203,7 & 8,64 & 29,77 & $12: 49$ & 56,57 & 94,50 & 81,13 & 940,00 & 945,00 & 943,18 & 0,20 & $13: 00$ & 1086 \\
\hline 10/1/2007 & 28,84 & $17: 00$ & 20,84 & 05:20 & 24,05 & 202,68 & 6,45 & 29,77 & $12: 15$ & 64,93 & 93,30 & 83,58 & 940 & 945 & 942,22 & 21,60 & $10: 40$ & 960 \\
\hline $11 / 1 / 2007$ & 31,88 & $15: 30$ & 18,97 & $05: 50$ & 24,9 & 175,18 & 6,05 & 26,89 & $17: 16$ & 42,40 & 93,50 & 74,11 & 939 & 944 & 941,51 & 0,00 & $11: 40$ & 1108 \\
\hline $12 / 1 / 2007$ & 30,47 & $13: 40$ & 18,92 & 03:30 & 24,36 & 247,21 & 9,83 & 47,05 & $14: 33$ & 59,94 & 92,40 & 80,59 & 935 & 941 & 938,77 & 8,00 & $13: 20$ & 1101 \\
\hline 13/1/2007 & 27,55 & $16: 00$ & 21,28 & $21: 10$ & 23,52 & 223,75 & 6,95 & 35,53 & $20: 35$ & 68,50 & 93,90 & 86,39 & 935 & 939 & 937,09 & 12,6 & $16: 00$ & 657 \\
\hline $14 / 1 / 2007$ & 28,58 & $13: 40$ & 20,32 & $21: 30$ & 22,73 & 213,4 & 62,59 & 24,02 & $16: 00$ & 60,88 & 94,20 & 86,45 & 937 & 941 & 938,94 & 5,6 & $13: 30$ & 924 \\
\hline $15 / 1 / 2007$ & 24,31 & $11: 50$ & 18,89 & 06:00 & 20,91 & 138,87 & 6,62 & 29,77 & $16: 44$ & 77,30 & 94,10 & 89,99 & 940 & 944 & 941,97 & 25,6 & $11: 00$ & 862 \\
\hline $16 / 1 / 2007$ & 26,47 & $15: 00$ & 18,54 & 03:40 & 22,28 & 161,41 & 6,66 & 21,15 & 08:33 & 56,62 & 93,30 & 81,48 & 942 & 946 & 943,88 & 0,0 & $11: 00$ & 711 \\
\hline $17 / 1 / 2007$ & 29,86 & $16: 40$ & 20,52 & 05:00 & 23,57 & 181,53 & 7,06 & 35,53 & $17: 31$ & 59,89 & 92,90 & 81,42 & 940 & 945 & 942,93 & 0,4 & $13: 20$ & 1007 \\
\hline $18 / 1 / 2007$ & 28,16 & $15: 10$ & 19,81 & $22: 20$ & 21,55 & 206,99 & 7,52 & 75,82 & 03:46 & 69,05 & 94,10 & 90,55 & 940 & 945 & 942,74 & 34,8 & $13: 40$ & 874 \\
\hline 19/1/2007 & 30,37 & $15: 30$ & 20,17 & $00: 30$ & 24,60 & 176,53 & 4,90 & 18,27 & $15: 31$ & 60,79 & 94,10 & 81,9 & 940 & 945 & 942,9 & 1,0 & $13: 10$ & 1085 \\
\hline 20/1/2007 & 31,02 & $11: 50$ & 20,04 & $23: 40$ & 23,37 & 167,26 & 6,01 & 49,90 & $12: 47$ & 56,24 & 93,60 & 85,53 & 942 & 946 & 943,96 & 3,4 & $11: 30$ & 929 \\
\hline $21 / 1 / 2007$ & 28,74 & $16: 10$ & 19,41 & 05:20 & 22,55 & 160,78 & 6,05 & 38,41 & $17: 47$ & 63,19 & 94,20 & 86,4 & 943 & 947 & 944,98 & 8,4 & $13: 10$ & 1045 \\
\hline $22 / 1 / 2007$ & 26,38 & $15: 20$ & 20,16 & 05:50 & 22,37 & 170,03 & 10,91 & 29,77 & 08:57 & 65,53 & 90,40 & 82,02 & 943 & 946 & 944,56 & 0,2 & $15: 20$ & 686,4 \\
\hline 23/1/2007 & 24,68 & $17: 50$ & 19,26 & 05:40 & 21,42 & 132,78 & 6,55 & 21,15 & 01:03 & 75,50 & 92,60 & 84,96 & 942 & 945 & 943,6 & 4,2 & $15: 20$ & 582,9 \\
\hline
\end{tabular}




\begin{tabular}{|c|c|c|c|c|c|c|c|c|c|c|c|c|c|c|c|c|c|c|}
\hline $24 / 1 / 2007$ & 30,7 & $15: 00$ & 18,03 & $05: 50$ & 23,68 & 144,08 & 5,72 & 26,89 & $17: 12$ & 49,88 & 93,60 & 77,73 & 940 & 946 & 943,41 & 0,2 & $13: 40$ & 1055 \\
\hline $25 / 1 / 2007$ & 28,83 & $12: 30$ & 19,43 & 05:40 & 23,25 & 171,18 & 5,72 & 47,05 & $12: 58$ & 55,94 & 92,90 & 83,67 & 941 & 945 & 943,13 & 6,2 & $11: 30$ & 1091 \\
\hline $26 / 1 / 2007$ & 30,47 & $16: 50$ & 21,43 & $23: 50$ & 24,88 & 224,63 & 7,09 & 29,77 & $12: 47$ & 54,34 & 92,80 & 79,07 & 941 & 945 & 943,06 & 1,0 & $12: 30$ & 1116 \\
\hline 27/1/2007 & 23,64 & $17: 30$ & 20,92 & 04:20 & 22,02 & 229,20 & 6,66 & 29,77 & $12: 32$ & 78,90 & 94,30 & 91,21 & 941 & 945 & 943,15 & 63,0 & $10: 20$ & 243,8 \\
\hline $28 / 1 / 2007$ & 29,46 & $15: 10$ & 21,25 & $21: 10$ & 23,26 & 309,74 & 9,32 & 44,17 & $17: 40$ & 56,67 & 93,40 & 84,67 & 939 & 944 & 942,38 & 10,0 & $13: 20$ & 1056 \\
\hline 29/1/2007 & 28,86 & $16: 40$ & 21,1 & 02:20 & 23,61 & 271,84 & 9,22 & 35,53 & $14: 17$ & 62,02 & 93,80 & 84,24 & 939 & 944 & 941,85 & 8,8 & $12: 30$ & 1145 \\
\hline $30 / 1 / 2007$ & 31,59 & $14: 20$ & 21,25 & $01: 20$ & 25,01 & 230,97 & 7,34 & 29,77 & $17: 37$ & 52,30 & 93,50 & 79,93 & 940 & 944 & 942,36 & 4,4 & $12: 50$ & 1104 \\
\hline $31 / 1 / 2007$ & 31,88 & $15: 00$ & 20,32 & 05:40 & 25,17 & 184,18 & 7,74 & 24,02 & $16: 50$ & 45,46 & 90,90 & 75,18 & 940 & 944 & 942,46 & 0 & $11: 10$ & 1092 \\
\hline
\end{tabular}




\section{REFERÊNCIAS BIBLIOGRÁFICAS}

AIDAR, $H$. et al. Bean producion and White mould incidence under no till system. Annual Report of the Bean Improvement Cooperative, East Lansing, v.43, p. 150-151, 2000.

AITA, C. et al. Plantas de cobertura do solo como fonte de nitrogênio ao milho. Revista Brasileira de Ciência do Solo, Viçosa, v.25, p. 157-165, 2001.

ALVAREZ, R. et al. Soil organic carbon, microbial biomass and CO2-C production from three tillage systems. Soil and Tillage Research, v. 33, p. 1728, 1995.

ALVES, A.C. et al. Métodos para quantificar a volatilização de amônia em solo fertilizado com uréia. In: REUNIÃO DA SOCIEDADE BRASILEIRA DE ZOOTECNIA, 43., 2006, João Pessoa. Anais... Pessoa. Anais: SBZ, 2006. 1 CD-ROM.

ALVES, V. M. C. et al. Milho. In: RIBEIRO, A. C.; GUIMARÃES, P. T. G.; ALVAREZ V, V. H. (Ed.). Recomendação para uso de corretivos e fertilizantes em Minas Gerais. Viçosa: Comissão de fertilidade do Solo do Estado de Minas Gerais, 1999, 359 p.

AMADO, T. J. C.; MILNICZUK, J.; FERNANDEZ, S. B. V. Leguminosas e adubação mineral como fonte de nitrogênio para o milho em sistemas de reparo do solo. Revista Brasileira de Ciências do Solo. Viçosa, v. 24, p.179189, 2002.

AMBROSANO, E. J. Dinâmica do nitrogênio dos adubos verdes, crotalária juncea (crotalária juncea) e mucuna-preta (Mucuna aterrima) em dois solos cultivados com milho. 1995. 83 f. Tese (Doutorado) - Escola Superior de Agricultura "Luis de Queiroz", Universidade de São Paulo, Piracicaba, 1995. 
ANFAR / SINDIRAÇÕES. Matérias-primas para alimentação animal: Padrão, Sindirações/ANFAR. São Paulo: Ministério da Agricultura e Reforma Agrária, 1999.

ASSOCIATION OF OFFICIAL ANALYTICAL CHEMISTS (AOAC). Official Methods of Analyses of the Association of Official Analytical Chemists. 11.ed. Washington DC, 1970. v.1, 1015p.

AZAM, F.; MALIK, K. A.; SAJJDAD, M. I. Transformations in soil and availability to plants of ${ }^{15} \mathrm{~N}$ Applied as inorganic fertilizer and legume residues. Plant and Soil, Dordrecht, v.86, p. 3-13, 1985.

BALKO, L.G.; RUSSEL, W.A. Response of maize inbred line to $\mathrm{N}$ fertilizer. Agronomy Journal, Madison, v. 72, p. 723-728, Sept./Oct. 1980.

BARBOSA FILHO, M. P., FAGERIA, N. K.; SILVA, O. F. da. Aplicação de nitrogênio em cobertura no feijoeiro irrigado. Santo Antônio de Goiás: EMBRAPA Arroz e Feijão, 2001 8p. (Circular Técnica, 49).

BARTEZ, H., R. Dinámica dos nutrients e adubação em sistemas de produção sob plantio direto. Disponível em: http://www.rau.edu.uy/agro/uepp/siembra6.htm>. Acesso em: 28 dez. 2006.

BASSOI, L.H. \& REICHARDT, K. Acúmulo de matéria seca e de nitrogênio em milho cultivado no período de inverno com aplicação de nitrogênio no solo e via água de irrigação. Pesquisa Agropecuária Brasileira, Brasília, v. 30, n. 12, p. 1361-1373, 1995.

BAYER, C.; MIELNICZUK, J. Conteúdo de nitrogênio total num solo submetido a diferentes métodos de preparo e sistemas de cultura. Revista Brasileira de Ciência do Solo, Viçosa, v. 21, p. 235-239, 1997.

BELOW, F. E. Fisiologia, nutrição e adubação nitrogenada do milho. Piracicaba: POTAFOS, 2002. p. 7-12. (Informações Agronômicas, 99). 
BELOW, F.E. Nitrogen metabolism and crop productivity. In: PRESSARAKLI, M. Handbook of plant and crop physiology. New York: Marcel Dekker, 1995. p. 275-301.

BERTOL, I.; COGO, N.P. \& LEVIEN, R. Comprimento crítico de declive em sistemas de preparos conservacionistas de solo. Revista Brasileira de Ciência do Solo, 21:139-148, 1997.

BLACK, A.S.; SHERLOCK, R.R.; SMITH, N.P. Effects of form of nitrogen, season, and urea application rate on ammonia volatilization from pastures. New Zealand Journal of Agricultural Research, Wellington. v. 28, n.4, p. 469-474, 1985.

BLACK, A.S.; SHEROLOCK, R.R.; SMITH, N.P. Effect of timing of simulated rainfall on ammonia volatilisation from urea applied to soil of varying moisture content. Journal of Soil Science, Wellington. v.38, n.4, p.679-688, 1987.

BOUWMEESTER, R.J.B.; VLEK, P.L.G.; STUMPE, J.M. Effect of environmental factors on ammonia volatilization from urea-fertilized soils. Soil Science Society of America Journal, Washington, v. 49, n.2, p. 376-381, 1985.

BOUYOUCOS, G.J. The hydrometer as a new ad rapid method for determining the colloidal content of soil. Soil Science, Madison, v. 23, n. 4, p. 319-331, 1927.

Brasil. Servico Nacional de Pesquisas Agronômicas. Comissão de Solos. Levantamento de reconhecimento dos solos do Estado de São Paulo. Rio de Janeiro, Ministério da Agricultura, 1960. 634p. (Boletim, 12).

BÜLL, L.T. Nutrição mineral do milho. In: BÜLL, L.T.; CANTARELLA, H. Cultura do milho: fatores que afetam a produtividade. Piracicaba: POTAFOS, 1993. p. 63-146.

BYRNES, B.H. Liquid fertilizers and nitrogen solutions. In: INTERNATIONAL FERTILIZER DEVELOPMENT CENTER. Fertilizer manual. Alabama: Kluwer Academic, 2000. p.20-44. 
BYRNES, B.H. Liquid fertilizers and nitrogen solutions. In: INTERNATIONAL FERTILIZER DEVELOPMENT CENTER. Fertilizer manual. Alabama: Kluwer Academic, 2000. cap.2, p. 20-44.

CAMARGO, F.A.O.; SÁ, E.L.S. Nitrogênio e adubos nitrogenados. In: BISSANI, C. A.; GIANELO, C.; TEDESCO, MARINO, J.; CAMARGO, F. A. O. Fertilidade dos solos e manejo da adubação de culturas. Porto Alegre: Gênesis, 2004. p. 93-116.

CAMARGO, P.B. Dinâmica do nitrogênio dos fertilizantes: uréia $\left({ }^{15} \mathrm{~N}\right)$ e aquamônia $\left({ }^{15} \mathrm{~N}\right)$ incorporados ao solo na cultura cana-de-açúcar. 1989. 104p. Dissertação (Mestrado em Solos e Nutrição de Plantas) - Escola Superior de Agricultura “Luiz de Queiroz", Universidade de São Paulo, Piracicaba, 1989.

CAMPOS, A. X. Fertilização com sulfato de amônio na cultura do milho em um solo do cerrado de Brasília sob pastagem de Brachiaria decumbens. 2005. 119p. Tese (Doutorado) - Escola Superior de Agricultura "Luiz de Queiroz", Universidade de São Paulo, Piracicaba, 2005.

CANTARELLA, $\mathrm{H}$. et al. Antecipação de $\mathrm{N}$ em milho em sistema de plantio direto usando ${ }^{15} \mathrm{~N}$-uréia. In: CONGRESSO BRASILEIRO DE CIÊNCIA DO SOLO, 29., 2003, Ribeirão Preto: Resumos...Ribeirão Preto, SBCS, 2003. 1 CD-ROM.

CANTARELLA, $\mathrm{H}$. et al. Avaliação Agronômica de Fertilizantes Nitrogenados. In: PETROFÉRTIL (Brasília, DF) Relatório Bienal (1986/1987). Brasília: EMBRAPA/ PETROFÉRTIL, 1988. p. 33-48.

CANTARELLA, $\mathrm{H}$. et al. Perdas de nitrogênio por volatilização da amônia e resposta da cana-de-açúcar à adubação nitrogenada, em sistema de colheita de cana sem queima prévia. STAB. Açúcar, Álcool e Subprodutos, v.8, n. 1, p. 25, set./out., 1999.

CANTARELLA, H.; DUARTE, A. P. Manejo da fertilidade do solo para a cultura do milho. In: GALVÃO, J. C. C.; MIRANDA, G. V. Tecnologia de produção de milho. Viçosa: UFV, 2004, p. 139-182. 
CANTARELLA, H.; RAIJ, B. van. Adubação nitrogenada no estados de São Paulo. In: SANTANA, M.B.M. (Ed.) SIMPÓSIO SOBRE ADUBAÇÃO NITROGENADA NO BRASIL. 1986, Ilhéus, BA. Anais... Ilhéus: Centro de Pesquisa de Cacau e Sociedade Brasileira de Ciência do Solo, 1986. p. 47-79.

CANTARELLA, H.; TABATABAI, M.A. Volatilização de amônia de alguns fertilizantes nitrogenados aplicados a solos. In: CONGRESSO BRASILEIRO DE CIÊNCIA DO SOLO, 20., 1985. Belém. Resumos... Belém: SBCS. 1985. p. 90.

CERETTA, C. A.; FRIES, M.R. Adubação nitrogenada no sistema plantio direto. In: NUERNBERG, N.J. (Ed.). Conceitos e fundamentos do sistema plantio direto. Lages: SBCS, 1998. p. 111-120.

COELHO, A. M. et al. Balanço do nitrogênio ${ }^{15} \mathrm{~N}$ em Latossolo VermelhoEscuro, sob vegetação de cerrado, cultivado com milho. Revista Brasileira de Ciências do Solo, Viçosa, v.95, n.2, p. 187-193, 1991.

COELHO, A. M.; CRUZ, J. C.; PEREIRA FILHO, I. A. Rendimento do milho no Brasil: chegamos ao máximo? Piracicaba: POTAFOS, 2003. p. 1-12. (Informações Agronômicas, n. 101).

COMISSÃO DE FERTILIDADE DO SOLO DO ESTADO DO RIO GRANDE DO SUL E SANTA CATARINA (CFS-RS/SC, 1995). Recomendações de adubação e de calagem para os estados do Rio Grande do Sul e de Santa Catarina. 3. ed. Passo Fundo: SBCS - Núcleo Regional Sul, 1995. 224p.

COMPANHIA NACIONAL DE ABASTECIMENTO. Avaliação da Safra Agrícola 2007/2008 - Quinto Levantamento - Fevereiro/2008. Disponível em: http://www.conab.gov.br/conabweb/download/safra/5 levantamento fev2008.p df. Acesso em: 20 de março 2008.

COSTA, M.C.G.; VITTI, G.C.; CANTARELLA, H. Volatilização de N-NH3 de fontes nitrogenadas em cana-de-açúcar colhida sem despalha a fogo. Revista Brasileira de Ciências do Solo, Viçosa, v.27, p. 631-637, 2003. 
CRUZ, A.P.; LARA CABEZAS, W.A.R. Adubação nitrogenada na cultura do milho. In: SIMPÓSIO SOBRE ROTAÇÃO SOJA/MILHO NO SISTEMA PLANTIO DIRETO, 2., 2001, Piracicaba. Palestra...Piracicaba:ESALQ/USP, 2001. Palestra.

DEANMEAD, O.T.; FRENEY J.R.; JACKSON, A.V. Volatilization of ammonia from urea and ammonium sulfate applied to sugarcane trash in North Queensland. In: AUSTRALIAN SOCIETY OF SUGAR CANE TECHNOLOGISTS CONFERENCE, v.12, n.1, 1990, Journsville. Proceedings... Journsville: Watson Fergunson, 1990, p. 72-78.

DENMEAD, O.T. Micrometeorological methods for measuring gaseous losses of nitrogen in the field. In: FRENEY, J.R.; SIMPSON, J.R. Gaseous loss of nitrogen from plant-soil systems. Hague: Martinus Nijhoff, 1983. v.9, p. 133157.

DIDONET, A.D. et al. Efeito da radiação solar e temperatura na definição do número de grãos em milho. Pesquisa Agropecuária Brasileira, Brasília, Brasília, DF, v. 37, p. 933-938, 2002.

DUARTE, A.P. Resposta de cultivares de milho ao nitrogênio no sistema de plantio direto e sua influência na qualidade de grão. 2003. p. 174. Tese (Doutorado em Fitotecnia) - Escola Superior de Agricultura "Luis de Queiroz", Universidade de São Paulo, Piracicaba, 2003.

ECHEVERRIA, H. E.; ROZAS, H. S. Fertilización nitrogenada bajo siembra direta. In: REUNIÃO BASSLEIRA DE FERTILIDADE DO SOLO E NUTRIÇÃO DE PLANTAS - Fertbio 2004, 26., 2004, Lages. Palestra... Lages, 2004. 1 CDROM.

EDMEADES, D.C.; JUDD, M.; SARATHCHANDRA, S.U.O. Effect of lime on nitrogen mineralization as measured by grass growth. Plant and Soil, v. 60, p. 177-186, 1981.

ELABBADI, K.; SMAILI, M.; MATERON, L. A. Competition between Medicago truncatuca and wheat for ${ }^{15} \mathrm{~N}$ labeled soil nitrogen and influence of phosphorus. Soil Biology and Biochemistry, Oxford, v.28, p. 83-88, 1996. 
EMPRESA BRASILEIRA DE PESQUISA AGROPECUÁRIA. Centro Nacional de Pesquisa de solos. Sistema brasileiro de classificação de solos. Rio de Janeiro, 1999. 412p.

EPSTEIN, E. Nutrição mineral das plantas: princípios e perspectivas. Trad. de E. Malavolta. São Paulo: EDUSP; Rio de Janeiro: Livros Técnicos e Científicos, 1975. 341 p.

ERNST, J.W.; MASSEY, H.F. The effects of several factors on volatilization of ammonia formed from urea in soil. Soil Science Society of America Proceedings, v. 24, n.1, p. 87-90, 1960.

ESPIRONELLO, A. Aplicação de aquamônia, uréia, nitrato de amônio e cloreto de potássio em cinco níveis, em três socas de cana-de-açúcar. In: CONGRESSO NACIONAL DA SOCIEDADE DOS TÉCNICOS AÇUCAREIROS DO BRASIL, 4., Olinda, 1987. Anais. Piracicaba: STAB, 1987. p. 94-102.

FANCELLI, A.L. Plantas alimentícias: guia para aula, estudo e discussão. CALQ: Piracicaba, LPV, 1986, 131p.

FANCELLI, A.L.; DOURADO NETO, D. Fenologia do milho. Informações Agronômicas FOTAFOS, Piracicaba, n. 78, p. 1-13, 1997.

FANCELLI, A.L.; DOURADO NETTO, D. Cultura do milho: aspectos fisiológicos e manejo de água. Informações Agronômicas POTAFOS. Piracicaba, n. 73, p. 1-6, 1996. Apresentado no SEMINÁRIO SOBRE FISIOLOGIA DA PRODUÇÃO E MANEJO DE ÁGUA E DE NUTRIENTES NA CULTURA DO MILHO DE ALTA PRODUTIVIDADE. 1., 1996, Piracicaba.

FEDERAÇÃO BRASILEIRA DE PLANTIO NA PALHA. Evolução da área de plantio direto no Brasil. Disponível em: < http://www.agri.com.br/febrapdp>. Acesso em: 20 abr. 2007.

FENN, L.B.; HOSSNER, L.R. Ammonia volatilization from ammonium or ammonium-forming nitrogen fertilizers. Advances in Soil Science, New York, v.1, p. 123-169. 1985. 
FENN, L.B.; MIYAMOTO, S. Ammonia loss and associated reactions of urea in calcareous soils. Soil Science Society of Ammerica Journal, v. 45, p. 537540, 1981.

FENN, L.B.; RICHARDS, J. Ammonia loss from surface applied urea-acid products. Fertilizer Research, v. 48, p. 578-582, 1984.

FERREIRA, A.C.B.; ARAUJO, P.R.G.; CARDOSO, A.A. Efeito da aplicação de $\mathrm{N}$, Mo, e Zn sobre a cultura do milho. In: CONGRESSO NACIONAL DE MILHO E SORGO, 21., 1996, Londrina. Resumos... Londrina: IAPAR, 1996. p. 149.

FOSTER, G.R.; JOHNSON, C.B. \& MOLDENHAUER, W.C. Critical slope lengths for unanchored cornstalk and wheat straw residue. Trans. Am. Soc. Agric. Eng., 25:935-939, 947, 1982.

FOX, R. H.; KERN, J.M.; PIEKIELEK, A. Nitrogen fertilizer source, and method and time of application effects on no-till corn yield and nitrogen uptakes. Agronomy Journal, Madison, v. 78, p. 741-746, 1986.

FRANCELLI, A.L.; DOURADO NETO, D. Produção de milho. Guaíba: Agropecuária, 2000. p. 360.

FRANCIS, D. D.; SCHEPERS, J. S.; VIGIL, M. S. Post-antesis nitrogen loss from corn. Agronomy Journal, Madison, v. 85, p. 659-653, 1993.

FREITAS, S.S. et al. Mineralização e imobilização de nitrogênio em solo plantado com torta de filtro e carbonato de cálcio. Revista Brasileira de Ciência do Solo, v. 12, p. 243-248, 1988.

FRENEY, J.R. et al. Estimating ammonia volatlization from flooded rice fields by simplified methods. Soil Science Society of America Journal, v.49, n. 4, p. 1049-1054, 1985.

FRENEY, J.R. et al. Factors controlling ammonia loss from trash covered sugarcane fields fertilized with urea. Fertilizer Research, The Hague, v.31, 341-349, 1992. 
FURLANI NETO, V.L.; RIPOLI, T.C.; VILLA NOVA, N.A. Biomassa de cada-deaçúcar: energia contida no palhiço remanescente de colheita mecânica. STAB. Açúcar, Álcool e Subprodutos, v. 15, n. 4, p. 24-27, 1997.

GAVA, G.J.C. Compartimentalização do nitrogênio no sistema solo-planta na implantação da semeadura direta no ciclo da cultura do milho. 2003. $125 \mathrm{f}$. Tese (Doutorado em Ciências) - Centro de Engenharia Nuclear na Agricultura, Universidade de São Paulo, Piracicaba, 2003.

GAVA, G.J.C. Utilização do nitrogênio da uréia $\left({ }^{15} \mathrm{~N}\right)$ e da palhada $\left({ }^{15} \mathrm{~N}\right)$ por soqueira de cana-de-açúcar no manejo sem despalha a fogo. Piracicaba, 1999. 81 f. Dissertação (Mestrado) - Centro de Engenharia Nuclear na Agricultura, Universidade de São Paulo.

GEE, S.W.; BAUDER, J.C. Particle size analysis. In: KLUTE, A. (Ed.). Methods of soil analysis: physical and mineralogical methods. Madison: American Society of Agronomy, part I, 2. ed. 1986. p.383-412. (Agronomy 9).

GOEDERT, W.J. Uso e manejo dos recursos naturais do cerrado: solo e clima. In: SIMPÓSIO SOBRE O CERRADO, 5., 1980, Brasília. Cerrado: uso e manejo. Brasília: 1980. p. 475-498.

GOLLANY, $\mathrm{H}$. et al. Nitrogen Leaching and denitrification in continuous corn as related to residue management and nitrogen fertilization. Disponível em: http://www.ars.usda.gov/research/publications/ publications.htm. Acesso em 20 jan. 2007.

GONÇALVES, C.N.; CERETTA, C.A.; BASSO, C.J. Sucessões de culturas com plantas de cobertura e milho em plantio direto e sua influência sobre o nitrogênio do solo. Revista Brasileira de Ciências do Solo, Viçosa, v.24, p. 153-159, 2000.

HANWAY, J. J. Defoliation effects on different corn (Zea mays L.) hybrids as influenced by plant population and stay of development. Agronomy Journal, Madison, v. 61, p. 534-538, 1966. 
HARGROVE, W.L. Soil, environmental, and management factors influencing ammonia volatilization under field conditions. In: BOCK, B.R.; KISSEL, D.E. (Ed.) Ammonia volatilization from urea fertilizers. Alabama: NFDC, TVA, 1988. cap. 2, p. 17-36.

HARPER; L.A.; SHARPE, R.R. Nitrogen dynamics in irrigated corn: Soil-plant nitrogen and atmospheric ammonia transport. Agronomy Journal, Madison, v.87, p. 669-675, 1995.

HARRISON, R.; WEBB, J. . A review of the effect of $\mathrm{N}$ fertilizer type on gaseous emissions. Advances in Agronomy, New York, v.73, p. 65-108, 2001.

HOEFT, R.G. Desafios para a obtenção de altas produtividades de milho e de soja nos USA. Piracicaba: Potafós, p. 1-4, 2003 (Informações Agronômicas, 104).

HOWARD, D. D.; ESSINGTON, M. E. Surface: applied limestone no the efficiency of urea: containing nitrogen sources for no-till corn. Agronomy Journal, Madison, v. 90, p. 523-529, 1998.

IVANKO, S. Recent progress in the use of $15 \mathrm{~N}$ in research on nitrogen balance studies sin soil plant relationship. In: INTERNATIONAL ATOMIC ENERGY AGENCY. Isotope and radiation in soil-plant relationships inclusid forestry: Viena: IAEA, 1972, p. 483-497.

JENKINSON, D.S.; AYANABA, A. Decomposition of carbon-14 labelled plant material under tropical conditions. Soil Science Society of America Journal, v. 41, p. 912-915, 1977.

JINGGUO, W.; BAKKEN, L.R. Competition for nitrogen during mineralization of plant residues in soil: microbial response to $C$ and $N$ availabitity. Soil Biology and Biochemistry, v. 29, p. 163-170, 1997.

KANNO, T. et al. Root biomass of Five tropical Grass pastures under continuous grazing in Brazilian savannas. Grassland Science, Tochigi, v.45, p. 9-14, 1999. 
KARLEN, J.R.; FLANNERY, R.L.; SADLER, E.J. Aerial accumulation and partitioning of nutrients by corn. Agronomy Journal, Madison, v. 80, p. 232242, 1988.

KEENEY, D. R. Nitrogen availability índices. In: PAGE, A. L.; MILLER, R. H.; KEENEY, D. R. (Ed.). Methods of soil analysis. Part 2. Chemical and Microbiological Properties. 2. Ed. Madison: ASA, 1982.

KELLER, G. D.; MENGEL, D. E. Ammonia volatilization from nitrogen fertilizers surface applied to no-till corn. Soil Science Society of America Journal, Madison, v. 50, p. 1060-1063, 1986.

KIEHL, J.C. Emprego de sais inorgânicos no controle da volatilização de amônia decorrente da aplicação de amônia no solo. Piracicaba, 1989. 180 p. Tese (Livre Docência) - Escola Superior de Agricultura "Luiz de Queiroz", Universidade de São Paulo.

KIEHL, J.C. Nitrogênio: Dinâmica e disponibilidade no solo. In: CURSO DE ATUALIZAÇÃO EM FERTILIDADE DO SOLO, 1., Ilha Solteira, 1987. Trabalhos apresentados. Campinas: Fundação Cargill, 1987. p. 139-157.

KILLHAM, K. Soil ecology. Cambridge: Cambridge University Press, 1994. p. 242.

KITUR, B.K. et al. Fate of 15N-depleted ammonium nitrate applied to no-tillage and conventional tillage maize. Agronomy Journal, Madison, v.76, p. 240-243, 1984.

KUNZ, K. The value of ammonium sulfate. I Apresentado ao Workshop sobre Manejo de Fertilizantes Nitrogenados e Sulfatados na Agricultura, Piracicaba, 2001.

LARA CABEZAS, W.A.R. et al. Balanço da adubação nitrogenada solida e fluida de cobertura na cultura do milho, em sistema plantio direto no Triângulo Mineiro (MG). Revista Brasileira de Ciência do Solo, Viçosa, v.24, p.363-376. 2000. 
LARA CABEZAS, W.A.R. et al. Calibration of a semi-open static collector for determination of ammonia volatilization from nitrogen fertilizers. Communications in Soil Science Plant Analysis, v. 30, n. 3 \& 4, p. 389-406, 1999.

LARA CABEZAS, W.A.R. et al. Influência da cultura antecessora e da adubação nitrogenada na produtividade de milho em sistema plantio direto e solo preparado. Ciência Rural, Santa Maria, v. 34, p. 1005-1013, 2004.

LARA CABEZAS, W.A.R. et al. Volatilização de amônia da uréia ${ }^{15} \mathrm{~N}$ e aquamônia- ${ }^{15} \mathrm{~N}$ aplicadas na cultura da cana-de-açúcar em condições de campo. In: CONGRESSO NACIONAL DA SOCIEDADE DOS TÉCNICOS AÇUCAREIROS DO BRASIL, 4, Olinda, 1987. Anais. Piracicaba: STAB, 1987. p. 94-102.

LARA CABEZAS, W.A.R. et al. Volatilização de $\mathrm{N}-\mathrm{NH}_{3}$ na cultura de milho: I. Efeito da irrigação e substituição parcial da uréia por sulfato de amônio. Revista Brasileira de Ciência do Solo, Viçosa, v.21, p.481-487, 1997a.

LARA CABEZAS, W.A.R.; TRIVELIN, P.C.O. Eficiência de um coletor semiaberto estático na quantificação de $\mathrm{N}^{-\mathrm{NH}_{3}}$ volatilizado da uréia aplicada ao solo. Revista Brasileira de Ciências do Solo, Campinas, v.14, p.345-352, 1990.

LOPES, A.S. et al. Sistema plantio direto: bases para o manejo da fertilidade do solo. São Paulo: ANDA, 2004. 110p.

MAKKAR, H. P. S. Chemical, protein precipitation and bioassays for tannins, effects and fate of tannins, and strateies to overcome detrimental effects of feeding tannin-rich feeds. In: SEMINAR OF THE FAO-CIHEAM SUB-NETWOR ON SHEEP AND GOAT NUTRITION, 9., 2001, Hammament, Tunisia. Vienna: FAO; IAEA, 2001.

MALAVOlTA, E.; VITTI, G.C.; OLIVEIRA, S.A. de. Avaliação do estado nutricional das plantas. Piracicaba: POTAFOS, 1989. 201p.

MALAVOLTA, E.; VITTI, G.C.; OLIVEIRA, S.A. de. Avaliação do estado nutricional das plantas: princípios e aplicações. Piracicaba: Associação Brasileira para Pesquisa da Potassa e do Fosfato, 1997. 319p. 
MARTHA JÚNIOR, G.B. Balanço de ${ }^{15} \mathrm{~N}$ e perdas de amônia por volatilização em pastagem de capim elefante. Piracicaba, 1999. 75p. Dissertação (Mestrado) - Escola Superior de Agricultura "Luiz de Queiroz", Universidade de São Paulo.

MARTHA JÚNIOR, G.B. Produção de forragem e transformações do nitrogênio do fertilizante em pastagem irrigada de capim Tanzânia. Piracicaba, 2003. 149p. Tese (Doutorado) - Escola Superior de Agricultura "Luiz de Queiroz", Universidade de São Paulo.

MARTIN, J.P.; HAIDER, K. Microbial degradation and stablization of ${ }^{14} \mathrm{C}$-labeled lignins, phenols, and phenolic polymers in relation to soil humus formation. In: KIRK, T.K.; HIGUCHI, T.; CHANG, H.M. (Ed.) Lignin biodegradation: microbiology, chemistry and potential applications. Boca Raton: CRC Press, 1980. v.1. $77-100$.

MASCARENHAS, H. A. et al. Efeito residual do nitrogênio de soja na produção de milho. 2. ed. Campinas: IAC, 1983. 24 p. (Boletim Técnico, 58).

MEISINGER, J.J. et al. Nitrogen utilization the maize under minimal tilage and moldboard plow tillage: I four-year results using labeled $\mathrm{N}$ fertilizer na Atlantic coastal plain soil. Agronomy Journal, Madison, v.77, p. 602-611, 1985.

MELGAR, R.; CAMOZZI, M.E.; FIGUEROA, M.M. Guia de fertilizantes, enmiendas y productos nutricionales. Buenos Aires: Instituto Nacional de Tecnologia Agropecuária, 1999. cap. 1, p. 13-25: Nitrogenados.

MELLO, F.A.F. et al. Fertilidade do solo. São Paulo: Nobel, 1983. 400p.

MELLO, F.A.F. Uréia fertilizante. Campinas: Fudação Cargil, 1987. 192p.

MELO, W.J. Matéria orgânica, nitrogênio e enxofre: curso de atualização em fertilidade do solo. Jaboticabal: ANDA, 1978. 66 p. 
MENGEL, D. Manejo de nutrientes na cultura do milho de alta produtividade. Piracicaba: Potafós, 1996. 16p. (Informações Agronômicas, 73).

MITTELMANN, A. Variação genética para qualidade nutricional em milho com endosperma normal. 2001. 47 f. Dissertação (Mestrado em genética e Melhoramento de plantas)-Escola Superior de Agricultura Luiz de Queiroz, Universidade de São Paulo, Piracicaba, 2001.

MOHAMED, I.; JAMAL, I.; KARIMA, E. The use of ${ }^{15} \mathrm{~N}$ and ${ }^{32} \mathrm{P}$ isotopes in investigation of soil fertility under different cropping systems. Applied Radiation Isotopes, Oxford, v.46, p. 611-612, 1995.

MONESMITH, F.L. Mercado de fertilizantes nitrogenados: tendências internacionais e nacionais. IApresentado ao Workshop sobre Manejo de Fertilizantes Nitrogenados e Sulfatados na Agricultura, Piracicaba, 2001.

MORAGHAN, J.T. et al. Labeled nitrogen fertilizer research with urea in the semi-arid tropics. Plant and Soil, v.80, n.1, p. 21-33, 1984.

MORAIS, L.F.B. \& COGO, N.P. Comprimentos críticos de rampa para diferentes manejos de resíduos culturais em sistema de semeadura direta em um Argissolo Vermelho da Depressão Central (RS). Revista Brasileira de Ciência do Solo, 25:1041-1051, 2001.

MOREIRA, F.M.S.; SIQUEIRA, J.O. Transformações bioquímicas e ciclos dos elementos no solo. In: UFLA, 2002. 625p. cap. 7 . Microbiologia e bioquímica do solo. Lavras:

MURAOKA, T. et al. Eficiência de abonos verdes (crotalaria e mucuna) e urea, aplicadas no solos ou juntamente, como fuentes de $\mathrm{N}$ para o cultivo de arroz. Terra, Chapingo, v.20, n.1, p.17-23, 2002.

NEL, P.C.; SMITH, N.S.H. Growth and development stages in the growing maize plant. Farming in South Africa, p.1-7, 1978. 
NEPTUNE, A.M.L. et al. Efeitos de doses não eqüidistantes de $N, P$ e $K$ nas concentrações destes macronutrientes na folha e na produção do milho (Zea mays L.). In: . Estado nutricional das plantas, 1982, Piracicaba. Anais... Piracicaba: Escola Superior de Agricultura "Luiz de Queiroz", v. 39, p. 917-941, 1982.

NÖNMIK, H. The effect of pellet size on the ammonia loss from urea applied to Forest sois. Plant and Soil, v. 39, p. 309-318, 1973.

OLIVEIRA, J. B.; PRADO, H. Levantamento pedológico do Estado de São Paulo: quadrícula de São Carlos. II Memorial Descritivo. Boletim Técnico do IAC, n. 98, 1984, 188p.

OLIVEIRA, M.W. et al. Decomposição e liberação de nutrientes da palhada de cana-de-açúcar em campo. Pesquisa Agropecuária Brasileira. v. 34, n.12, p. 2359-2362, dez. 1999.

OLIVEIRA, M.W. et al. Volatilização de amônia proveniente da uréia $\left({ }^{15} \mathrm{~N}\right)$ aplicada em solo cultivado com cana-de-açúcar. In: Encontro Científico de Pós-graduados do CENA-USP, 3., Piracicaba, 1997. Anais...Piracicaba, CENA, 1997. p. 28.

OLIVEIRA, P.P.A. Manejo da calagem e da fertilização nitrogenada na recuperação de pastagens degradadas de Brachiaria sp. em solos arenosos. Piracicaba: Universidade de São Paulo, 2001. 110p. Tese (Doutorado) - Centro de Engenharia Nuclear na Agricultura, Universidade de São Paulo, 2001.

OLIVEIRA, S.A. Avaliação da mineralização e disponibilidade de nitrogênio para o trigo (Triticum aestivum L.) em solos do Distrito Federal. Piracicaba, 1987. 128 f. Tese (Doutorado) - Escola Superior de Agricultura "Luis de Queiroz", Universidade de São Paulo.

ORLANDO FILHO, J. et al. Efeitos do sistema de palhada (cana crua $x$ cana queimada) sobre algumas propriedades do solo. STAB. Açúcar, Álcool e Subprodutos, v. 16, n.6, p. 30-33, 1998.

PAUL, E.A.; CLARK, F.E. Soil microbiology and biochemistry. New York: Academic Press, 1989. 273p. 
PENATTI, C.P.; DONZELLI, J.L. Avaliação nutricional em cana colhida sem a queima da palha. Piracicaba: COPERSUCAR, 2001. p. 18. (Relatório final do Projeto $n^{\circ} 620$ - Fase P1 safras 99/00 e 00/01).

PRIMAVESI, O. et al. Adubação com uréia em pastagem de Cynodon dactylon cv. Coastcross sob manejo rotacionado: eficiência e perdas. São Carlos: Embrapa Pecuária Sudeste, 2001. 42p. (Circular Técnico 30).

RAIJ, B. van \& PEECH, M. Electrochemical properties of some Oxisols and Alfisols of the tropics. Soil Science Society of America Proceedings, Madison, v.36, p.587-593, 1972.

RAIJ, B. van. et al. Recomendações de adubação e calagem para o Estado de São Paulo. 2.ed. Campinas: Instituto Agronômico, 1996. 285 p. (Boletim Técnico, 100).

RAIJ, B. van. et al. Análise química do solo para fins de fertilidade. Campinas: Fundação Cargill, 1987. 170p.

RAIJ, B. van. et al. Gesso na produção de cultivares de milho com tolerância diferencial a alumínio em três níveis de calagem. Revista Brasileira de Ciência do Solo, 22:101-108, 1998.

RAIJ, B. van. Fertilidade do solo e adubação. Piracicaba: POTAFOS, 1991. $343 p$.

RAPPAPORT, B.D.; AXLEY, J.H. Potassium chloride for improved urea fertilizer efficiency. Soil Science Society of America Journal, Madison, v.48, n.2, p. 399-401, 1984.

RASHID, G.H. The volatilization loss of nitrogen from added urea in some soils of Bangladesh. Plant and Soil, v.48, n.3, p. 549-556, 1977.

REICHARDT, K. et al. Dinâmica do nitrogênio num solo cultivado com milho. Revista Brasileira de Ciências do Solo, Viçosa, v.3, p. 17-20, 1979. 
REYNOLDS, C.M.; WOLF, D.C.; ARMBRUSTER, J.A. Factors related to urea hydrolysis in soils. Soil Science Society America Journal, v.49. p. 104-108, 1987.

RIZZARDI, M.A. Manejo do nitrogênio no sistema plantio direto. In: SEMINÁRIO INTERNACIONAL DO SISTEMA PLANTIO DIRETO, 1., 1995, Passo Fundo, RS. Resumos...Passo Fundo: EMBRAPA-CNPT, 1995. p. 95-99.

RODRIGUES, M.B.; KIEHL, J.C. Distribuição e nitrificação da amônia proveniente da uréia aplicada ao solo. Revista Brasileira de Ciências do Solo, v.16, p. 403-408, 1992.

RODRIGUES, M.B.; KIEHL, J.C. Distribuição e nitrificação da amônia após o emprego de uréia em diferentes doses e modos de aplicação. Revista Brasileira de Ciências do Solo, Viçosa, v.10, p. 37-43, 1986.

SÁ, J.C. Manejo da fertilidade do solo no plantio direto. Castro: Fundação $A B C, 1993.96 \mathrm{p}$.

SÁ, J.C. Manejo do nitrogênio na cultura do milho no sistema plantio direto. Passo Fundo: Aldeia Norte, 1996. 24p.

SAINZ ROZAS, H.R.; ECHEVERRIA, H.E.; PICONE, L.I. Denitrification in maize under No-tillage. Soil Science Society of American Journal, Madison, v.65, p. 1314-1323, 2001.

SAN, C.K. The simple open soil method of measuring urea volatilization losses. Plant and Soil, v.92, n.1, p. 73-79, 1986.

SANGOI, L. et al. Volatilização de $\mathrm{N}^{-N_{3}}$ em decorrência da forma de aplicação de uréia, manejo de resíduos e tipo de solo, em laboratório. Ciência Rural, Santa Maria, v.33, p. 687-692, 2003.

SAS INSTITUTE. The SAS-System for Windows release 6.11 (software). Cary: SAS Institute Inc., 1996. 
SAVANT, N.K.; JAMES, A.F.; MCCLELEAN, G.H. Effect of amountes and sequence of additions of urea and water on hydrolysis of surface-applied granular urea in unsaturated soils. Fertilizer Research, v.11, p. 231-234, 1987.

SCHÄEFER, M.J. et al. Erosão em entressulcos em diferentes preparos e estados de consolidação do solo. Revista Brasileira de Ciência do Solo, Viçosa, MG, v.25, n. 2, p. 431-441, abr./jun. 2001.

SCIVITTARO, W.B. et al. Transformações do nitrogênio proveniente de mucuna-preta e uréia utilizados como adubo na cultura do milho. Revista Brasileira de Ciência do Solo, Viçosa v.24, p.917-926, 2000.

SCIVITTARO, W.B. et al. Transformações do nitrogênio proveniente de mucuna-preta e uréia utilizados como adubo verde na cultura do milho. Pesquisa Agropecuária Brasileira, Brasília, v.38, p. 1427-1433, 2003.

SEGUY, L.; BOUZINAC, S.; MATSUBARA, M. Gestão dos solos e das culturas nas fronteiras agrícolas dos cerrados úmidos do Centro-oeste. Lucas do Rio Verde: CIRAD, 1992. 117p.

SENGIK, E.; KIEHL, J.C. Controle da volatilização de amônia em terra tratada com uréia e turfa pelo emprego de sais inorgânicos. Revista Brasileira de Ciência do Solo, Viçosa, v.19, n. 3, p. 329-492, 1995.

SEXTON, B.T. et al. Optimizing nitrogen and irrigation inputs for corn based on nitrate leaching and yield on a course-textured soil. Journal Environment Quality, Vienna, v.25, p. 983-992, 1996.

SHARPE, R.R.; HARPER, L.A. (1995) Soil, plant and atmospheric condition as they relate to ammonia volatilization. Fertilizer Research 42, 149158.doi:10.1007/BF00750509.

SILVA, E.C. et al. Efeito da época e forma de aplicação da adubação nitrogenada na cultura do milho no sistema de plantio direto no cerrado. In: CONGRESSO BRASILEIRO DE CIÊNCIA DO SOLO, 26., 1997, Rio de Janeiro. Resumo... Rio de Janeiro: SBCS, 1997. 
SILVA, J.C.A. Movimento e perdas por lixiviação de nitrogênio $\mathrm{CO}\left({ }^{15} \mathrm{NH}_{2}\right)_{2}$ em um Alfisol cultivado com milho (Zea mays, L.). 1982. 68p. Dissertação (Mestrado em Solos e Nutrição de Plantas) - Escola Superior de Agricultura "Luiz de Queiroz", Universidade de São Paulo, Piracicaba, 1982.

SILVEIRA, J.E. da; STONE, L.F. Teores de nutrientes e de materia orgânica afetados pela rotação de culturas e sistemas de preparo do solo. Revista Brasileira de Ciência do Solo, Viçosa, v.25, n.2, p. 387-394, 2001.

SIMS, J.T. et al. Evaluation of soil and plant nitrogen tests for maize on manured soils of the Atlantic Coastal-Plain. Agronomy Journal, Madison, v. 87, p. 213-222, 1995.

SIQUEIRA, J.O.; FRANCO, A.A. Biotecnologia do solo: fundamentos e perspectivas. Brasília: ABEAS; MEC; ESALQ, FAEPE, 1988, 232p.

SOGBEDJI, J.M.; Van es, H.M.; YANG, C.L. Nitrate leaching and nitrogen budget as affected by maize nitrogen rate and soil type. Journal of Enviromental Quality, Vienna, v.29, n.6, p. 1813-1820, 2000.

SOUSA, D.M.G.; LOBATO, E. Cerrado: correção do solo e adubação. 2. ed. Planaltina: Embrapa Cerrados, 2004. 416p.

STARK, J.C.; JARREL, W.M.; LETEY, J. Evaluation of irrigation-nitrogen management practices for celery using continous-variable irrigation. Soil Science Society American Journal, Madison, v.47, p. 95-98, 1983.

SUBIRÓS, J.F.; BERTSCH, F. Utilización de fertilizantes líquidos nitrogenados em três ciclos de producción comercial de caña de azúcar em Guanacaste. Agronomia Costarricense, v.22, n.1, p. 89-98, 1998.

TEDESCO, M.J.; VOLKWEISS, S.J. \& BOHNEM, H. Análises de solo, plantas e outros materiais. Porto Alegre, Universidade Federal do Rio Grande do Sul, 1985. 118p. 
TERMAN, G.L. Volatilization losses of nitrogen as ammonia from surfaceapplied fertilizers, organic amendments, and crop residues. Advances in Agronomy, v. 31, p. 189-223, 1979.

TIMMONS, D.R.; BAKER, J.K. Fertilizer management effect on recovery of labeled nitrogen continuous no till. Agronomy Journal, Madison, v.84, p. 490496, 1992.

TIMMONS, D.R.; CRUSE, R.M. Effect of fertilization method and tillage on nitrogen-15 recovery by corn. Agronomy Journal, Madison, v.82, p. 777-784, 1990.

TISDALE, S.L.; NELSON, W.L.; BEATON, J.D. Soil fertility and fertilizers. 4th ed. New York: Macmillan, 1985.

TRIVELIN, P.C.O. Técnica com traçador ${ }^{15} \mathrm{~N}$ em estudos de perdas gasosas de nitrogênio do solo. Piracicaba, 2001. Apostila do programa de pós-graduação em energia nuclear na agricultura, CENA/USP.

TRIVELIN, P.C.O.; LARA CABEZAS, W.A.R.; BENDASOLLI, J.A. Coletor semi aberto estático para estimar perdas reais de amônia de fertilizantes nitrogenados aplicados ao solo. In: CONGRESSO BRASILEIRO DE CIÊNCIAS DO SOLO, 26., 1997, Rio de Janeiro. Anais... Rio de Janeiro: SBCS, 1997.

TRIVELIN, P.C.O.; LARA CABEZAS, W.A.R.; BOARETTO, A.E. Dinâmica do nitrogênio de fertilizantes fluidos no sistema solo-planta. In: VITTI, G.C.; BOARETTO, A.E. Fertilizantes fluidos. Piracicaba: Potafós, 1994. p. 314-330.

TUNDISI, J.G. Água no Século XXI: enfrentando a escassez. São Carlos: RiMa IIE, 2003. 248p.

UHART, S.A.; ANDRADE, F. H. Deficiency in maize: I. Effects on crop growth, development, dry matter partitioning, and kernel set. Crop Science, Madison, v. 35, p. 1376-1383, 1995. 
ULHOA, A.M.C.; LIMBARDI, L.P.; REICHARDT, K. Utilização do nitrogênio por dois híbridos de milho. Campinas: Fundação Cargill, 1982. 66p.

URBAN, W.J. et al. Evaluation of urea-urea posphate as nitrogen sources for no-tillage production. Soil Science Society American Journal., v. 51, p. 242246, 1987.

VAN SOEST, P.J.; Development of a comprehensive system of feed analysis and its application to forage. Journal of Animal Science, v. 26, n.1, p. 119128, 1967.

VAN SOEST, P.J.; ROBERTSON, J.B.; LEWIS, B.A. Symposium: Carbohydrate metodoloy, metabolism, and nutritional implications in dairy cattle. Methods for dietary fiber, neutral detergent fiber, and nonstarch polysaccharides in relation to animal nutrition. Journal of Dairy Science., v. 74, p.3583-3597. 1991.

VARSA. E.C. et al. Nitrogen placement in no-till corn. In: PROCEEDINGS OF NORTH CENTRAL EXTENSION-INDUSTRY SOIL FERTILITY CONFERENCE, 1995, St. Louis. Proceedings... St. Louis: Potash \& Phosphate Institute, 1995. p. 69-74.

VICTORIA, R.L.; PICOLO, M.C.; VARGAS, A.A.T. O ciclo do nitrogênio. In: CARDOSO, E.J.B.N.; TSAI, S.M.; NEVES, M.C.P. (Coord.). Microbiologia do solo. Campinas: Sociedade Brasileira de Ciência do Solo, 1992. p. 105-120.

VITTI, G.C. et al. Características físicas e químicas da mistura entre uréia e sulfato de amônio. In: CONGRESSO BRASILEIRO DE CIÊNCIA DO SOLO, Londrina, 2001. Anais. Londrina: SBCS, 2001b. p. 312.

VITTI, G.C.; MALAVOLTA, E.; COUTINHO, E.L.M. Uso de fertilizantes nitrogenados e portadores de enxofre: SIMPÓSIO BRASILEIRO SOBRE FERTILIZANTES NA AGRICULTURA BRASILEIRA, Ilhéus, 1984. Anais. EMBRAPA: Ilhéus, 1984. p. 205-253.

VITTI, A.C. Utilização pela cana-de-açúcar (cana planta) do nitrogênio da uréia $\left({ }^{15} \mathrm{~N}\right)$ e do mineralizado no solo em sistemas de manejo com e sem queima. Piracicaba, 1998. p. 93. Dissertação (Mestrado) - Centro de Engenharia Nuclear na Agricultura, Universidade de São Paulo. 
VOLK, G.M. Volatile loss of ammonia following surface application of urea to turf or bare soils. Agronomy Journal, Madison, v.51, n.12, p. 746-749, 1959.

WARNCKE, D.; BARBER, S. Ammonium and nitrate uptake by corn (Zea mays L.) influenced by nitrogen concentrations and $\mathrm{NH}_{4}{ }^{+} / \mathrm{NO}_{3}{ }^{-}$ratio. Agronomy Journal, Madison, v. 65, p. 950-954, 1973.

WENG, T.H.; LI, S.W. Nitrogen mineralization potencial and rate in soil. Taiwan Sugar, v.39, n. 3, p. 8-11, May/June 1992.

WHITEHEAD, D.C. Volatilization of ammonia. In: Wallingford: CAB international, 1995, p. 152-179. Grassland nitrogen.

WOOD, A.W. Management of crops residues following Green harvesting of sugarcane in North Queensland. Soil \& Tillage Research, Elsevier Science Publishers B.V., Amsterdam, v. 20, p. 69-85, 1991.

YAMADA, T. Adubação nitrogenada do milho: como melhorar a eficiência? Piracicaba: POTAFOS, 1995. p. 3. (Informações Agronômicas, 71).

YAMADA, T. Adubação nitrogenada do milho: quanto, como e quando aplicar. Piracicaba: POTAFOS, 1996. p. 5. (Informações Agronômicas, 74).

YAMADA, T. O nitrogênio e o potássio na adubação da cultura do milho. Informações Agronômicas POTAFOS, Piracicaba, n. 78, p. 1-4, 1997.

YAMADA, T.; ABDALLA, S.R.S. Como melhorar a eficiência da adubação nitrogenada do milho?. Informações Agronômicas POTAFOS , Piracicaba, n. 91 , p. 1-5, 2000.

YAMADA, T.; ABDALLA, S.R.S. Simpósio discute sistema agrícola sustentável com colheita econômica máxima: Integração Lavoura-pecuária e o manejo de plantas daninhas: Piracicaba, Potafós, p. 1-20, 2004 (Informações Agronômicas, 106). 